\title{
New insights on Tournaisian-Visean (Carboniferous, Mississippian) athyridide, orthotetide, rhynchonellide, and strophomenide brachiopods from southern Belgium
}

\author{
Bernard Mottequin and Eric Simon
}

\begin{abstract}
Twelve selected Carboniferous species belonging to seven genera of the orders Athyridida, Orthotetida, Rhynchonellida, and Strophomenida (Brachiopoda) from southern Belgium are revised and/or discussed, and sometimes photographed for the first time since their first description dating back to the $19^{\text {th }}$ century. The investigated material originates from the historical type areas of the Tournaisian and Visean stages (Tournai and Visé, respectively) and from the Waulsortian carbonate buildups developed in the Namur-Dinant Basin. Two species are new (Leptagonia franca sp. nov., Serratocrista scaldisensis sp. nov.), and a new name is proposed (Nucleospira hannoniae nom. nov.) to solve the primary homonymy between Athyris globulina de Koninck and $A$. globulina Waagen. Taxonomic discussion involves selection of the holotype of Retzia intermedia de Koninck (definitely not an athyridide) and of lectotypes for several species of athyridides (Athyris globulina de Koninck, A. vittata de Koninck, and Retzia davidsoni de Koninck), and strophomenides (Orthis cylindrica M'Coy, Schellwienella radialiformis Demanet, and $S$. ornata Demanet). The palaeoecology of the investigated species and their biotic interactions with other organisms (e.g., drill holes, epizoans) are described. The analysis of the published data on the athyridides, orthotetides, and strophomenides occurring in southern Belgium during the Devonian-Mississippian reveals that our knowledge of these suspension-feeders in this part of the southern margin of Laurussia is currently insufficient to assess the aftermath of the different biological crises that took place during this time span, notably the Hangenberg Crisis at the end of the Famennian.
\end{abstract}

Bernard Mottequin. Royal Belgian Institute of Natural Sciences, Operational Directorate Earth and History of Life, rue Vautier 29, B 1000 Brussels, Belgium. bmottequin@naturalsciences.be

Eric Simon. Royal Belgian Institute of Natural Sciences, Operational Directorate Earth and History of Life, rue Vautier 29, B 1000 Brussels, Belgium. ericsimon98brach@gmail.com

Keywords: Brachiopoda; taxonomy; new species; palaeobiology; Devonian-Mississippian; Belgium

Submission: 23 January 2017 Acceptance: 24 May 2017

http://zoobank.org/8541AA1E-F9DE-4079-AE09-918FFF61ADC1

Mottequin, Bernard and Simon, Eric. 2017. New insights on Tournaisian-Visean (Carboniferous, Mississippian) athyridide, orthotetide, rhynchonellide, and strophomenide brachiopods from southern Belgium. Palaeontologia Electronica 20.2.28A: 1-45 palaeo-electronica.org/content/2017/1884-tournaisian-visean-brachiopods 


\section{INTRODUCTION}

The Tournaisian-Visean brachiopod assemblages are generally characterized by the predominance of productides and spiriferides (e.g., Curry and Brunton, 2007) that proliferated in numerous shallow water environments. This is especially true in southern Belgium, which is the historical type area of the Tournaisian and Visean stages (Hance et al., 2006a, 2006b), where brachiopods commonly occur in the mixed carbonate-siliciclastic shelf-ramp environments that stretched from southern Belgium and northern France to southern Ireland across southern Wales and south-western England during the Tournaisian-Visean time span (Figure 1). Carboniferous brachiopods from Western Europe received attention very early in the history of palaeontology, notably in Ireland and in the UK (e.g., Martin, 1793, 1809; Phillips, 1836; M'Coy, 1844; Davidson, 1858-1863). In Belgium, a large part of the Mississippian brachiopods was described in the pioneering works of de Koninck (e.g., 1843, 1847, 1851, 1887), de Ryckholt (1851), and Demanet (e.g., 1923, 1934, 1938, 1941), but most of them remain unrevised.

Besides representatives of the orders Productida and Spiriferida, the Tournaisian-Visean bra- chiopod assemblages from southern Belgium (Namur-Dinant Basin (Figure 1); see below) frequently include athyridides, orthotetides, and strophomenides. The athyridides were the first brachiopods to be described in this area (Léveillé, 1835).

The purposes of this paper are (1) the taxonomic description and/or revision of some athyridides, orthotetides, rhynchonellides, and strophomenides from the Tournaisian-Visean succession of southern Belgium (Namur-Dinant Basin), (2) to discuss their palaeobiology, and (3) to provide information on their Devonian-Carboniferous representatives (apart from the rhynchonellides).

\section{GEOLOGICAL SETTING}

Lower Carboniferous rocks outcrop in southern Belgium on both sides of the major Midi-Eifel fault zone, notably in the Brabant Parautochton, the Haine-Sambre-Meuse Overturned Thrust Sheets, and the Dinant Synclinorium (Hance et al., 1999; Belanger et al., 2012) (Figure 2). These Variscan structural elements constituted the NamurDinant Basin that developed along the southeastern margin of Laurussia during Devonian and Mis-

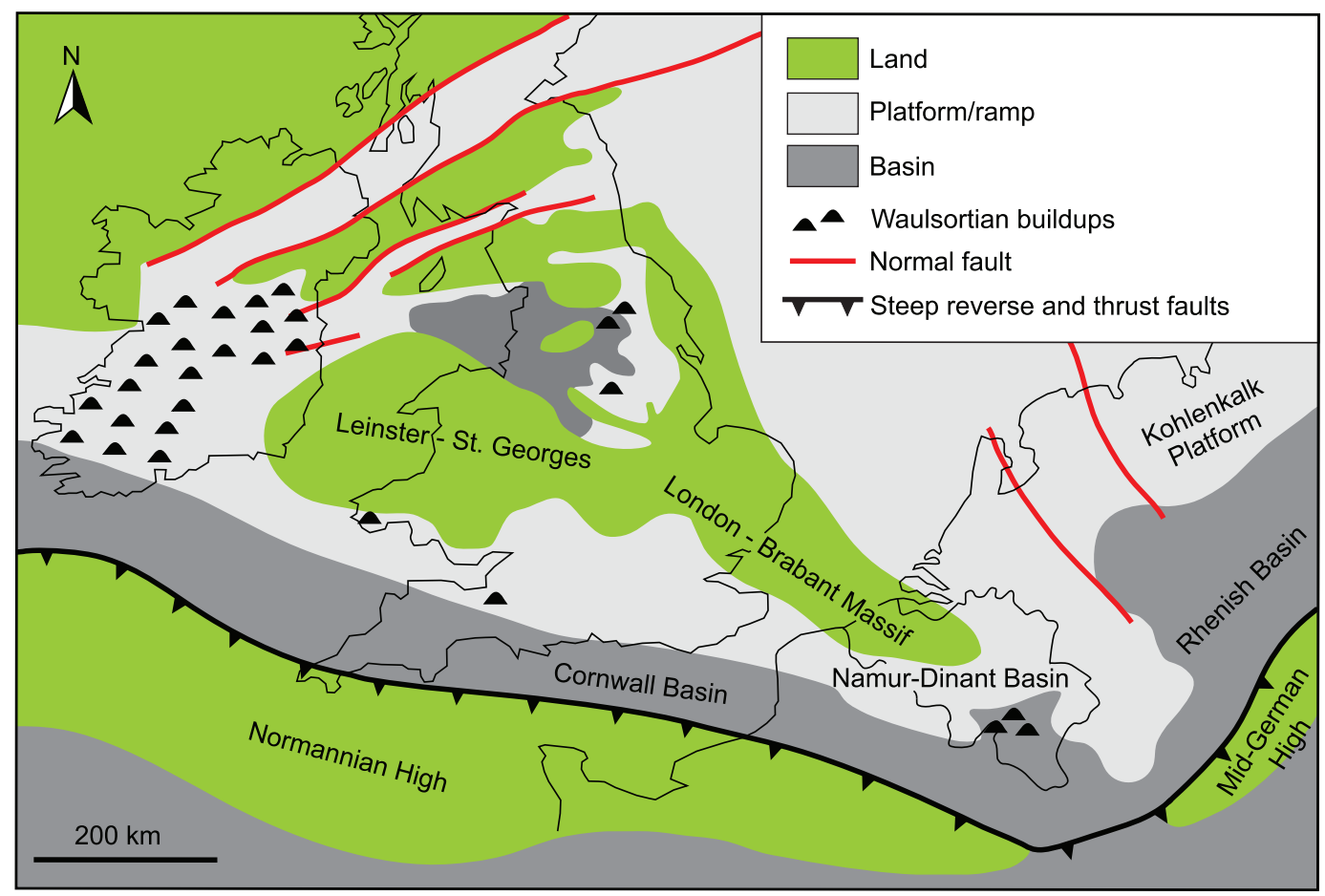

FIGURE 1. General context of Lower Carboniferous sedimentation in north-western Europe showing the distribution of emergent areas and Waulsortian buildups at the end of the Tournaisian (modified from Ziegler, 1990; Devuyst and Dehantschutter, 2007). 


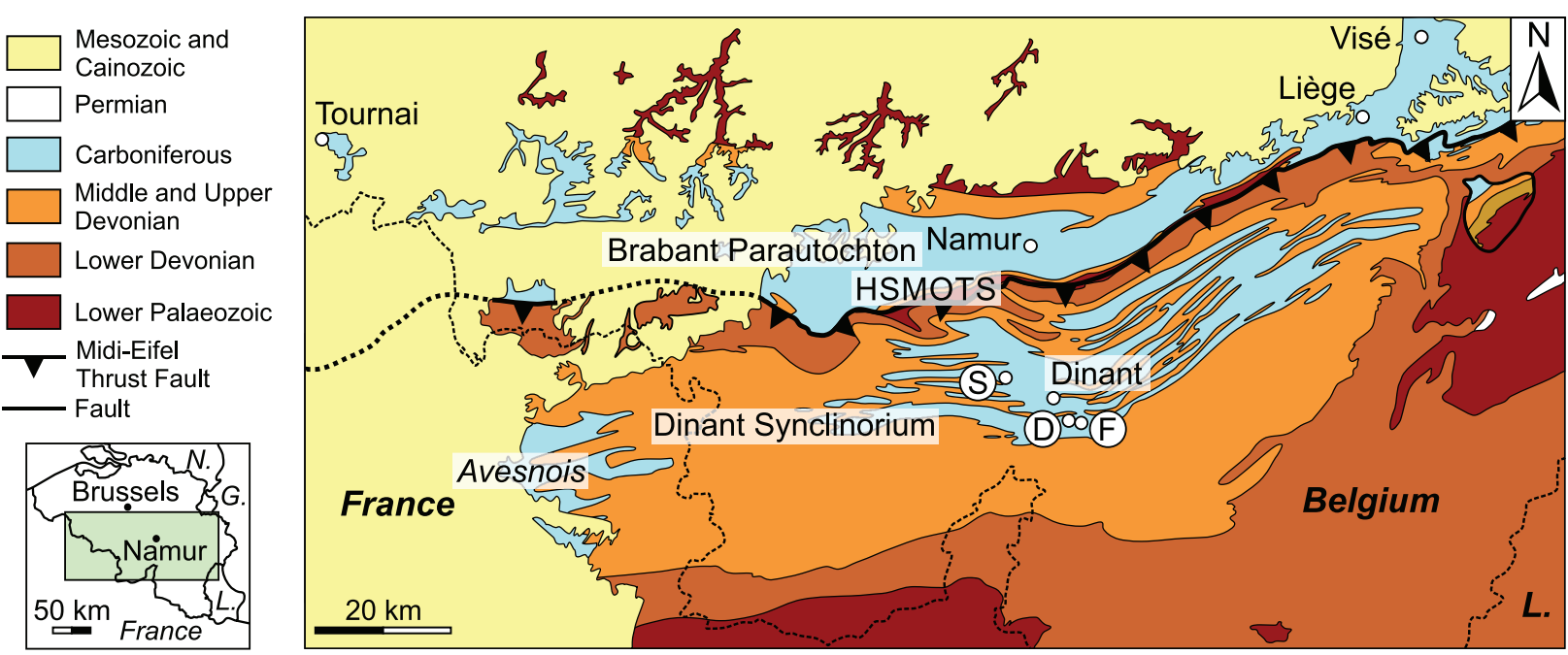

FIGURE 2. Schematic geological map of southern Belgium with location of the fossiliferous localities (modified from de Béthune, 1954). Abbreviations: D, Dréhance; F, Furfooz; G, Germany; HSMOTS, Haine-Sambre-Meuse Overturned Thrust Sheets; L, Grand Duchy of Luxemburg; N, The Netherlands; S, Sosoye.

sissippian times. The Tournaisian-Visean lithostratigraphy of southern Belgium was summarized by Poty et al. (2002), and several sedimentation areas (see below) were recognized in the Namur-Dinant Basin by Poty $(1997,2016)$ and Hance et al. (2001) (Figure 3). During the upper Visean, the Visé-Maastricht sedimentation area was not connected to the Namur-Dinant Basin and evolved to a graben that was open to the Campine Basin (Poty et al., 2002). The studied material comes from localities situated in the Hainaut (Tournai area), Dinant (Dréhance, Furfooz, Sosoye), and Visé-Maastricht (Visé) sedimentation areas.

Correlations of the Tournaisian (Hastarian, Ivorian) and Visean (Moliniacian, Livian, and Warnantian) Belgian substages, which are used here,

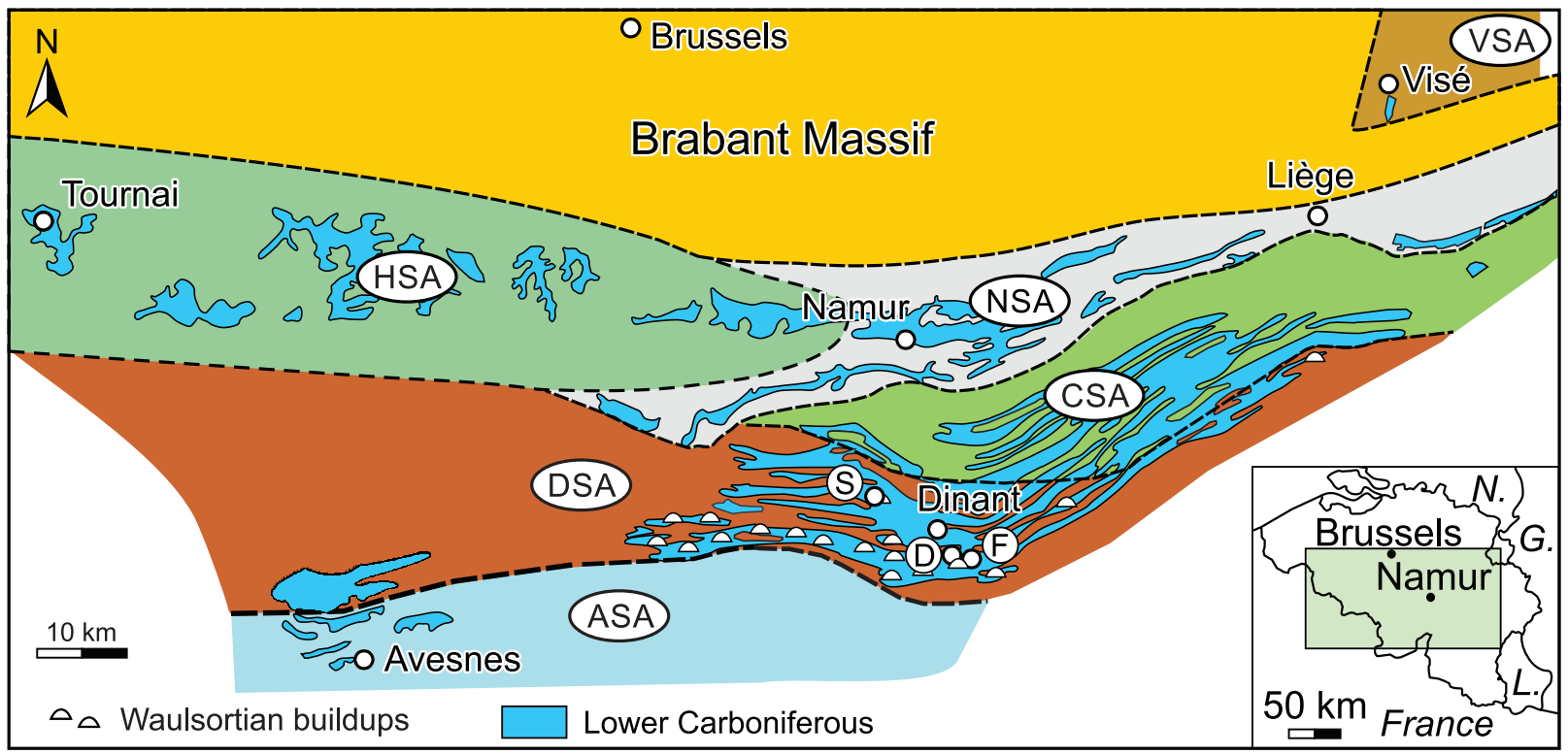

FIGURE 3. Late Tournaisian sedimentation areas in the Namur-Dinant Basin (not palinspastically restored; modified from Hance et al., 2001; Poty et al., 2006; Poty, 2016) with location of the fossiliferous localities. Abbreviations: ASA, Avesnois sedimentation area; CSA, Condroz sedimentation area; D, Dréhance; DSA, Dinant sedimentation area; $F$, Furfooz; G, Germany; HSA, Hainaut sedimentation area; L, Grand Duchy of Luxemburg; N, The Netherlands; NSA, Namur sedimentation area; S, Sosoye; VSA, Visé-Maastricht sedimentation area. 


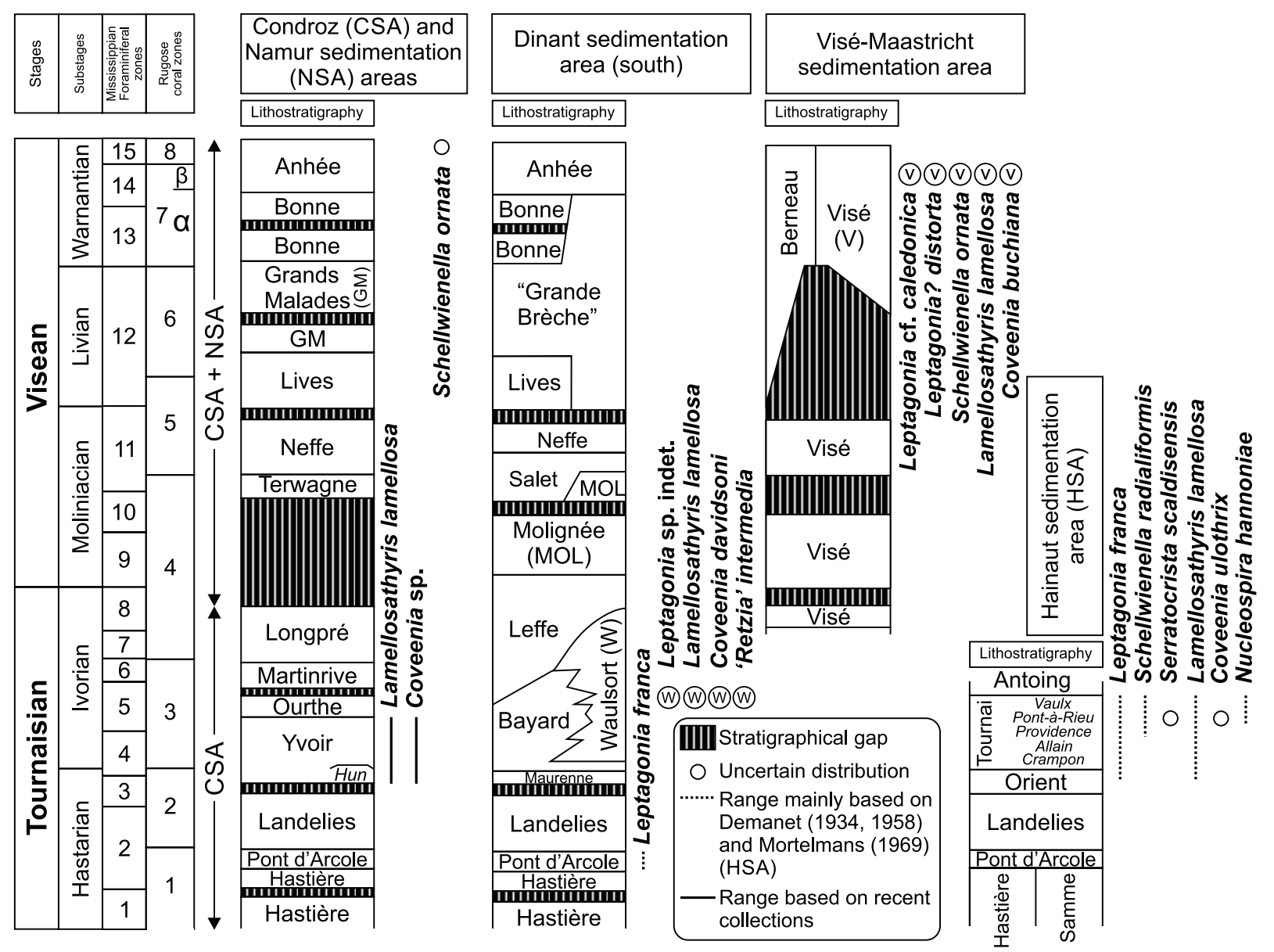

FIGURE 4. Distribution of the athyridides, orthotetides and strophomenides described and/or discussed herein within the essentially carbonate Tournaisian and Visean succession of southern Belgium (see text). Stratigraphy, lithostratigraphy (incompletely represented here for the Hainaut and Visé-Maastricht sedimentation areas; formations and members are in roman and italic letters, respectively), and biostratigraphy are adapted from Poty et al. (2002, 2006, 2014). The lenticular Vignobles Member is not represented here as it is rarely developed (it is comprised between the Vaulx Member of the Tournai Formation and the Antoing Formation). Note that the "Grande Brèche" is an informal stratigraphic unit resulting from the dissolution of evaporitic levels in the Grands Malades Formation; other brecciated horizons occur in the Lives Formation.

with other chronostratigraphic units, were discussed notably by Poty et al. (2006, 2014).

The material investigated herein mostly belongs to several very old collections (e.g., de Ryckholt, de Koninck, and Dewalque), of which the exact provenance is rarely known as is also the case for the stratigraphic level, although it is possible to constrain it with recent data (information are provided below). It is the reason for which we only indicate 'Tournai area' for the type locality of new species based on material from these old collections (see comment below).

The material from Tournai is from the Tournai Formation of Tournaisian age comprising dark, thin-bedded, siliceous, and argillaceous limestones with shaly and marly intercalations and with abundant chert nodules at some levels (Figure 4). Most of the specimens from Tournai were collected in pocket solutions in which the specimens were silicified, but precise location and stratigraphic levels are generally lacking (see discussion in Demanet, 1958). Some of the specimens are from the former Dutoit quarry now flooded (see Demanet, 1958) and the active Lemay quarry at Vaulx, south-east of Tournai (see Hennebert, 1996). The Tournai Formation is comprised between the Orient and the Antoing formations. The Orient Formation (Tournaisian, latest Hastarian) includes dark grey calcareous shales, with crinoidal limestone beds (ca. $60 \mathrm{~m}$ thick) (e.g., Mortelmans, 1969; Poty, et al., 2002). The Antoing Formation (ca. $170 \mathrm{~m}$ thick; Tournaisian-Visean [mostly Ivorian to Moliniacian]) lithologically resembles the Tournai Formation, but the beds are 
slightly thicker (e.g., Poty et al., 2002). Six members have been identified within the Tournai Formation, which is up to $145 \mathrm{~m}$ thick in its type area. They are from the base to the top: the Crampon, Allain, Providence, Pont-à-Rieu, Vaulx, and Vignobles members (see description in Poty et al., 2002) (Figure 4). Where the lenticular Vignobles Member is not developed as represented in Figure 4, the Vaulx Member, extends up to a thin clay marker probably of volcanic origin (Gaillard et al., 1999) known as the 'Gras Délit' (Poty et al., 2002), which marks the top of the formation. The limestones (mudstones, wackestones, and sometimes packstones [see Hennebert, 1996]) of the Tournai Formation are still intensively quarried for the production of cement, aggregate, and building stone and exposed in large and deep quarries. The Tournai Formation represents the nearly in situ accumulation of remains from a crinoid-brachiopod-bryozoan community with associated tabulate and solitary rugose corals, gastropods, bivalves, nautiloids, and trilobites; plurilocular foraminifers are very scarce and algae are almost absent (Hennebert, 1996 (see also for sedimentological and bathymetric interpretation); Gaillard et al., 1999). The biostratigraphical range of this formation, in terms of the Mississippian Foraminifer Zones (MFZ) of Devuyst and Hance (in Poty et al., 2006), spans the interval MFZ4 to MFZ5 (top of the Hastarian and lower part of the Ivorian) according to Hance et al. (2006a). For more details concerning the Tournai Formation, as well as the Lower Carboniferous succession in the Tournai area, see Hennebert and Doremus (1997a, 1997b) and Poty et al. (2002). Due to the scarcity of the microfossils (foraminifers, conodonts), correlations with the well-dated sections of the Namur-Dinant Basin are not possible (Mortelmans, 1973; Poty et al., 2002), but detailed studies on brachiopods may bring new elements for correlation in the future.

The material from Dréhance (de Koninck, 1887), Furfooz (de Koninck, 1887), and Sosoye (Demanet, 1923) (Figures 2-3) was recovered from Waulsortian carbonate buildups (Waulsort Formation; Figure 4) that developed in a ramp setting during the Tournaisian (Ivorian) and only occur within the Dinant sedimentation area (e.g., Lees, 1982, 1997, 2006; Hance et al., 2001) (Figures 34). The Waulsort Formation, of which the thickness varies between 0 and $300 \mathrm{~m}$, includes a large range of massive limestones and diagenic dolostones (Poty et al., 2002). Its biostratigraphical range spans the interval MFZ4 (top of the Hastar- ian) to MFZ8 (top of Ivorian) according to Hance et al. (2006a).

The Visé Formation (Ivorian-Warnantian, with stratigraphic gaps; MFZ8-MFZ14) crops out exclusively in a series of disused quarries south of Visé (Figures 2-4) (e.g., Pirlet, 1967; Hance et al., 2006b). Most of the fossils from Visé have been recovered from quarry F-G (e.g., Demanet, 1958; Pirlet, 1967; Poty, 1982; Hance et al., 2006b; Poty and Delculée, 2011), where exposures still exist although the rocks are unfortunately inaccessible. Its thickness is comprised between zero and several hundreds of meters due to major syn-sedimentary tectonics (e.g., Poty and Delculée, 2011). Four main facies composed of pale to grey limestones are distinguished among this lithostratigraphic unit (see Poty et al., 2002 for more details). Most of the macrofossils that contributed to the fame of the Visean fauna were collected within buildups composed of massive algal and bioclastic boundstones (Poty et al., 2002) belonging to the MFZ14. According to Aretz and Chevalier (2007), this particular lithofacies is close to the Cracoean facies of England (Mundy, 1994), which are also well-known for their rich brachiopod fauna (e.g., Brunton and Mundy, 1994).

\section{MATERIAL AND METHODS}

The bulk of the material investigated is curated at the Royal Belgian Institute of Natural Sciences (prefixed RBINS), Brussels, and complemented by specimens housed at the Department of Geology (palaeontological collections) of the University of Liège (prefixed ULg.PA). Additional material is housed at the Natural History Museum (prefixed BMNH), London, and at the National Museum of Ireland (Geological Collection, Natural History Division; prefixed NMING), Dublin.

\section{SYSTEMATIC PALAEONTOLOGY}

The supraspecific classification follows Cocks and Rong (2000) for Order Strophomenida, Williams and Brunton (2000) for Suborder Orthotetidina, and Alvarez and Rong (2002) and Alvarez (2007) for Order Athyridida. Only the illustrated material is registered.

Most of the synonymy lists refer only to the material from southern Belgium. The first monograph on Mississippian faunas from southern Belgium by de Koninck was published in several fascicules between 1842 and 1844, which are conventionally found in libraries as a bound volume cited with this combined date (Godefroid et al., 
2006). De Koninck $(1847,1851,1887)$ invariably cited 1843 for his earlier work on brachiopods. As explained by Mottequin and Simon (2017), we have here opted for 1843 in conformity with de Koninck's works. It is useful to stress here on the fact that a large part of Demanet's (1934) monograph is based on an unpublished work of de Koninck, which would have been included in a monograph to be published in the Annales du Musée royal d'Histoire naturelle de Belgique, but the latter died in 1887 before completing his opus.

Phylum BRACHIOPODA Duméril, 1805

Subphylum RHYNCHONELLIFORMEA Williams et al., 1996

Class STROPHOMENATA Williams et al., 1996

Order STROPHOMENIDA Öpik, 1934

Superfamily STROPHOMENOIDEA King, 1846

Family RAFINESQUINIDAE Schuchert, 1893

Subfamily LEPTAENINAE Hall and Clarke, 1894 Genus LEPTAGONIA M'Coy, 1844

Type species. Producta analoga Phillips, 1836, from the Visean Pendleside Limestone Group of Bowland, Yorkshire, England.

Leptagonia franca sp. nov.

Figures 4-8, Table 1

\section{zoobank.org/27FA86CF-03F3-456B-9667-C89DB981FE3E}

p $\quad 1843$

Leptaena depressa; de Koninck, p. 215, pl. 13, fig. 6a-c (labelled Leptaena depressa var. analoga Sowerby in the plate legend).

\begin{tabular}{|c|c|c|}
\hline$p$ & 1851 & Leptaena analoga; de Koninck, p. 653. \\
\hline$p$ & 1868 & $\begin{array}{l}\text { Strophomena (Producta) analoga; } \\
\text { Dewalque, p. } 333 .\end{array}$ \\
\hline$p$ & 1881 & $\begin{array}{l}\text { Strophomenes (Producta) analoga; } \\
\text { Mourlon, p. } 47 .\end{array}$ \\
\hline $\mathrm{v}$ & 1933 & Leptaena analoga; Maillieux, p. 92. \\
\hline v & 1934 & $\begin{array}{l}\text { Leptaena analoga (Phillips); Demanet, p. } \\
61 \text {, text-figs. } 11-14 \text {, pl. } 5 \text {, figs. 1-14. }\end{array}$ \\
\hline & 1950 & $\begin{array}{l}\text { Leptaena analoga Wilckens (sic); } \\
\text { Termier and Termier, pl. 82, figs. 19-20. }\end{array}$ \\
\hline $\mathrm{p}$ & 1958 & $\begin{array}{l}\text { Leptaena analoga (Phillips); Demanet, } \mathrm{p} \text {. } \\
123,126,130 .\end{array}$ \\
\hline $\mathrm{p}$ & 1969 & $\begin{array}{l}\text { Leptaena analoga (Phill.); Mortelmans, } \\
\text { p. } 31 \text { (only those from the Tournai } \\
\text { Formation). }\end{array}$ \\
\hline $\mathrm{v}$ & 2017 & $\begin{array}{l}\text { Leptagonia sp. indet.; Mottequin and } \\
\text { Simon, fig. } 12 \mathrm{~d} \text {. }\end{array}$ \\
\hline
\end{tabular}

Etymology. From francus, a, um (Latin: of or belonging to the Franks, Frank), in reference to the rich Frank history of the town of Tournai.
Holotype. RBINS a5891 (Demanet, 1934, pl. 5, fig. 1) from Tournai (Tournai Formation) (Figure 5.1-6).

Paratypes. RBINS specimens from Tournai (Tournai Formation) illustrated by Demanet (1934) a5829 (pl. 1, fig. 30) (Figure 6.1-6), a5892 (pl. 5, fig. 2) (Figure 5.7-12), a5893 (pl. 5, fig. 3), a5894 (pl. 5, fig. 4), a5895 (pl. 5, fig. 5) (Figure. 6.7-12), a5896 (pl. 5, fig. 6) (Figure 7.1), a5897 (pl. 5, fig. 7) (Figure 7.10-13), a5898 (pl. 5, fig. 8), a5899 (pl. 5, fig. 9) (Figure 7.9), a5902 (pl. 5, fig. 12) (Figure 7.4-5), a5903 (pl. 5, fig. 13) (Figure 7.8), a5904 (pl. 5, fig. 14), a5905 (text-fig. 11), a5906 (text-fig. 13), a5907 (text-fig. 14) and herein a13099 (Figure 5.13-18), a13100 (Figure 6.13-17), 13101 (Figure 6.18-22), a13102 (Figure 6.23-27), a13103 (Figure 7.2), a13104 (Figure 7.6-7).

Additional material. RBINS: two ventral valves and 27 articulated specimens.

Type locality. Tournai area (Figures 2-3), southern Belgium.

Type stratum. Tournai Formation, Tournaisian (Figure 4).

Diagnosis. Shell large (up to $70 \mathrm{~mm}$ in width), with a subtrapezoidal to subrectangular outline in juveniles, but transversally subrectangular in mature specimens; cardinal extremities slightly mucronate in juveniles, but becoming acute to subrounded (due to development of lamellose shelly expansions) in mature specimens. Shell parvicostellate and rugate, with $11-15$ costae in $5 \mathrm{~mm}$ at $10 \mathrm{~mm}$ from the dorsal umbo; 15-22 rugae on ventral disc. Ventral muscle field subdiamond-shaped, raised anterolaterally, and anteriorly on a low pseudospondylium. Dorsal muscle platform raised above valve floor extending to about half length of the disc; dental sockets deep, well-defined; socket plates strongly divergent; dorsal marginal ridge well developed, with numerous mantle canals developed anteriorly and antero-laterally to it.

Description. Shell large (up to $70 \mathrm{~mm}$ in width), markedly wider than long, widest at hinge line in juveniles or posteriorly to hinge line in mature specimens, concavoconvex in lateral profile with sharp, dorsally directed geniculation, with a subtrapezoidal to subrectangular outline in juveniles, but transversally subrectangular in mature specimens; anterior commissure rectimarginate; anterior margin slightly rounded or emarginate; cardinal extremities slightly mucronate in juveniles, but becoming acute to subrounded (due to development of lamellose shelly expansions) in mature specimens. 


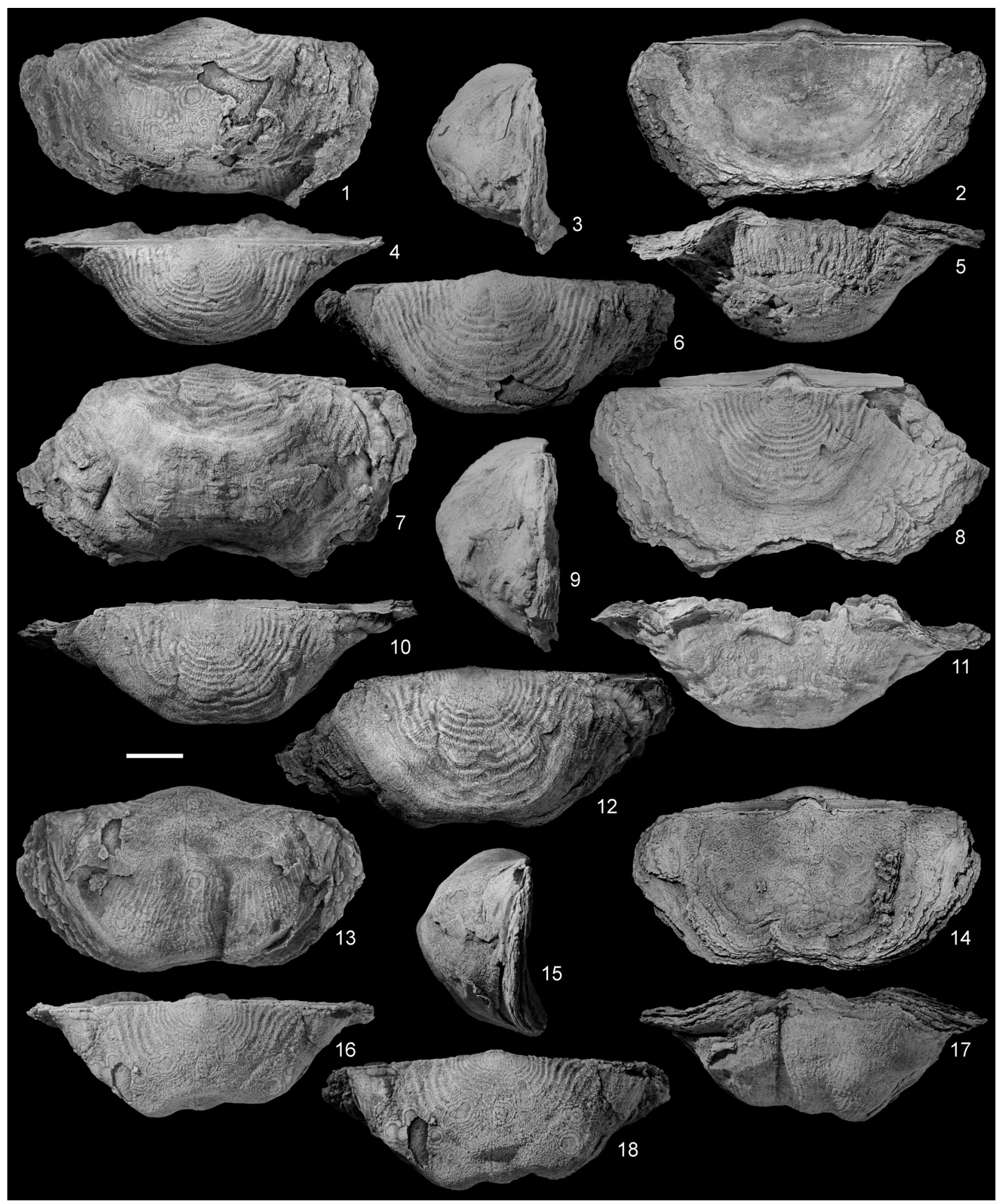

FIGURE 5. Leptagonia franca sp. nov. from the Tournai area, Tournai Formation (Tournaisian). 1-6, RBINS a5891 (holotype), articulated specimen, almost complete, in ventral (perpendicular to the surface of the alae), dorsal, lateral, posterior, anterior, and ventral (perpendicular to the disc) views. 7-12, RBINS a5892, articulated specimen, almost complete, in ventral (perpendicular to the surface of the alae), dorsal, lateral, posterior, anterior, and ventral (perpendicular to the disc) views. 13-18, RBINS a13099, articulated specimen (with an auloporid tabulate fixed to its right ventral flank), almost complete, in ventral (perpendicular to the surface of the alae), dorsal, lateral, posterior, anterior, and ventral (perpendicular to the disc) views. Scale bar equals $10 \mathrm{~mm}$. 


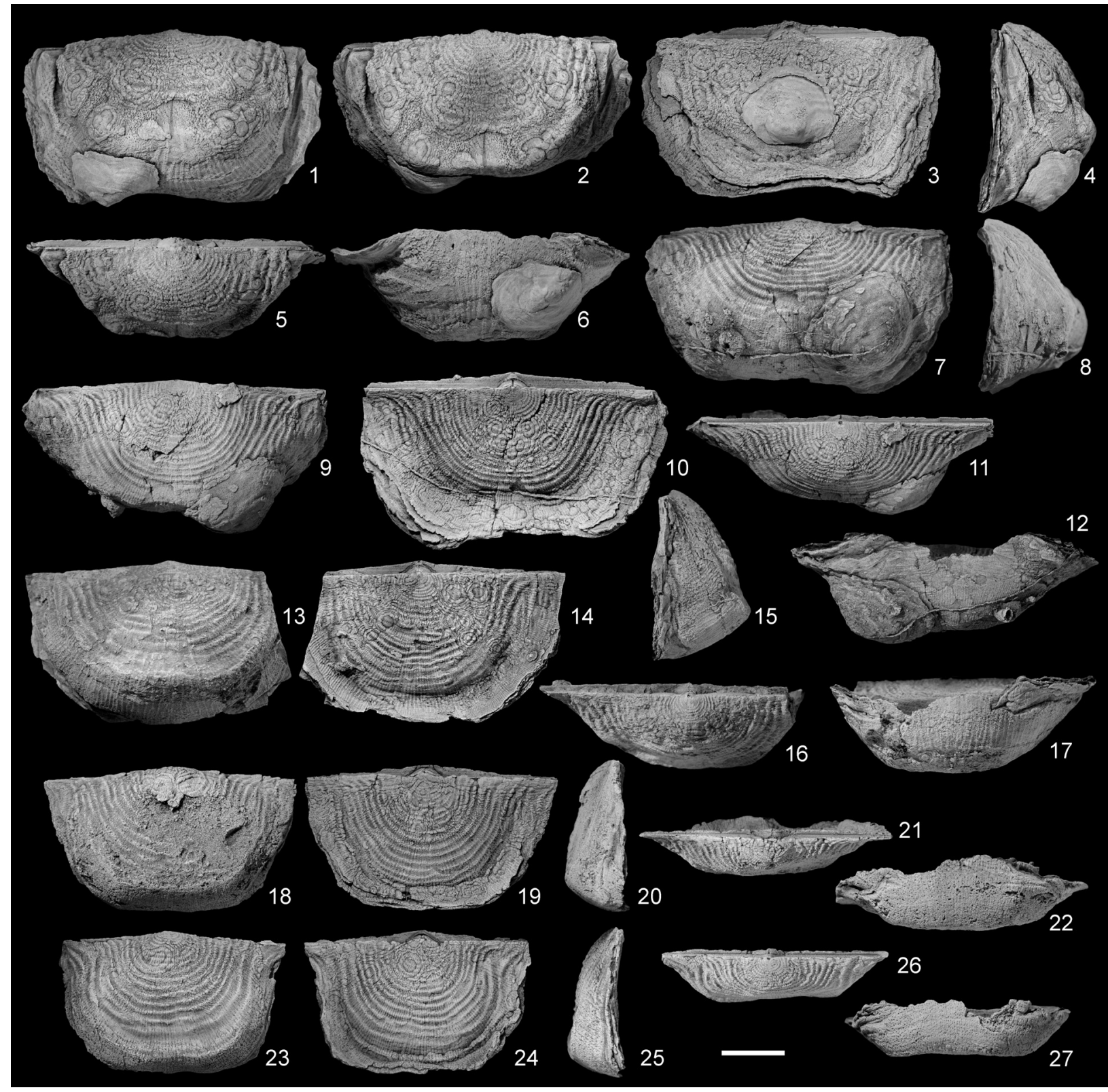

FIGURE 6. Leptagonia franca sp. nov. from the Tournai area, Tournai Formation (Tournaisian). 1-6, RBINS a5829, complete articulated specimen (with Petrocrania? ryckholtiana (de Koninck, 1843) attached to ventral and dorsal valves) in ventral (orientation as in Figure 5.1), ventral (perpendicular to the visceral disc), dorsal, lateral, posterior, and anterior views. 7-12, RBINS a5895, complete articulated specimen (with Petrocrania? ryckholtiana and microconchid attached to ventral valve), in ventral (orientation as in Figure 5.1), lateral, ventral (perpendicular to the visceral disc), dorsal, posterior and anterior views. 13-17, RBINS a13100, articulated specimen, almost complete, in ventral (orientation as in Figure 5.1), dorsal, lateral, posterior, and anterior views. 18-22, RBINS a13101, articulated specimen, almost complete, in ventral (orientation as in Figure 5.1), dorsal, lateral, posterior and anterior views. 2327, RBINS a13102, articulated specimen, almost complete, in ventral (orientation as in Figure 5.1), dorsal, lateral, posterior, and anterior views. Scale bar equals $10 \mathrm{~mm}$.

Ventral visceral disc shorter than trail in mature specimens, moderately convex longitudinally and transversally, subtrapezoidal in outline; umbo small; beak short; interarea low, striated parallel to hinge, apsacline to almost orthocline, weakly concave; apical foramen small (Figure 7.13 ); delthyrium broad, triangular, closed apically by a convex, striated pseudodeltidium; median depression developed anteriorly to geniculation in mature specimens. 


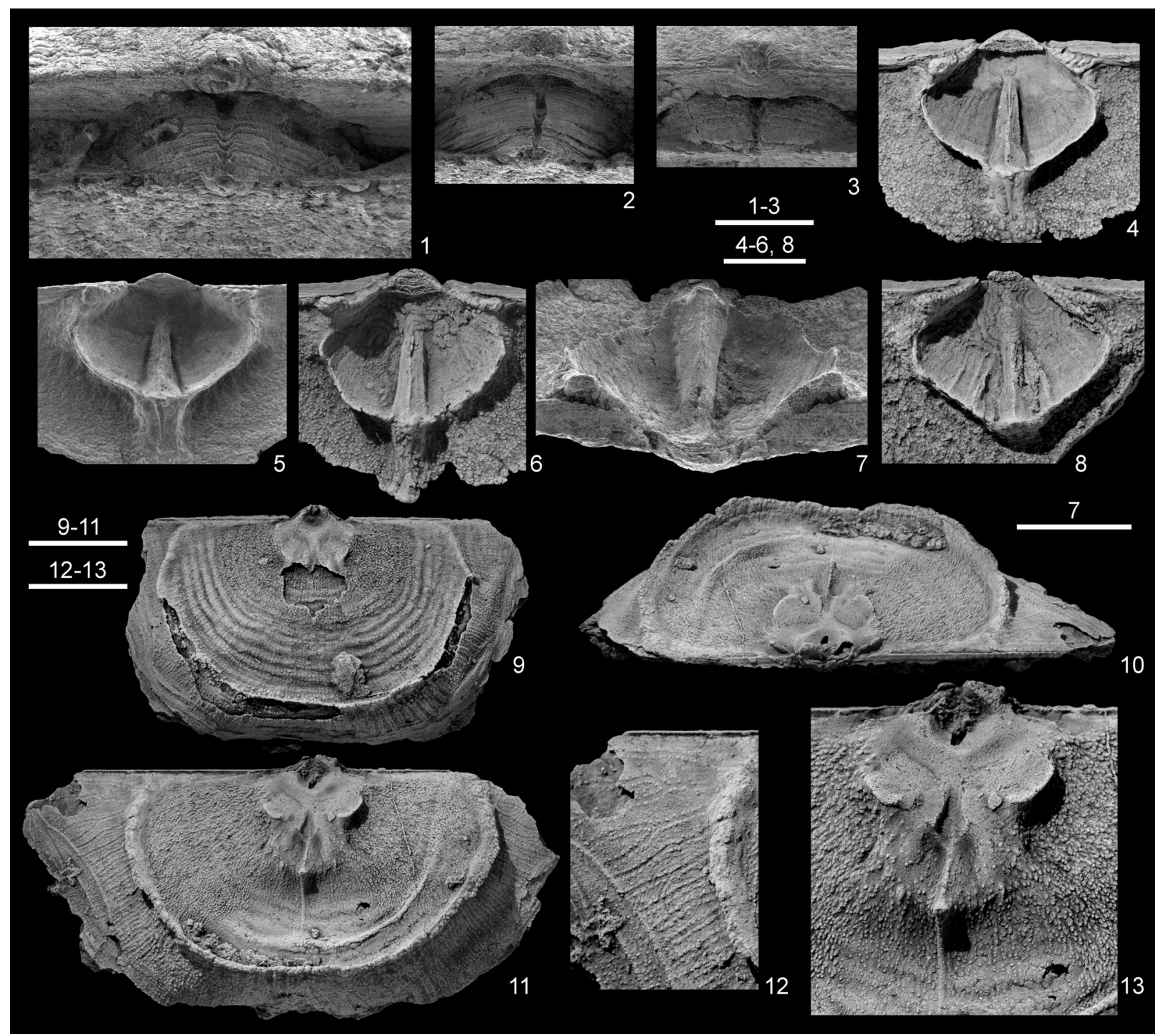

FIGURE 7. Leptagonia franca sp. nov. from the Tournai area, Tournai Formation (Tournaisian). 1-3, Detail of the small pseudodeltidium and apical foramen of three articulated specimens with the ventral valve on top: RBINS a5896 (1), RBINS a13103 (2), and RBINS a5895 (3). 4-5, RBINS a5902, incomplete ventral valve showing the posterior morphology. 6-7, RBINS a a13104, incomplete ventral valve interior showing the posterior morphology and posterior view notably displaying the prominent teeth. 8, RBINS a5903, incomplete ventral valve interior showing the posterior morphology. 9, RBINS a5899, almost complete dorsal valve interior in ventral view. 10-13, RBINS a5897, almost complete dorsal valve interior in posterior and ventral views, detail of the lateral vascular canals, and close-up of the cardinal process and the muscular field. Scale bars equal $2.5 \mathrm{~mm}(1-3), 5 \mathrm{~mm}(4-8,12-13), 10 \mathrm{~mm}(9-11)$.

Dorsal visceral disc flat longitudinally and transversally; trail shorter than disc; interarea clearly less developed than the ventral one, flat, apsacline, divided by convex, striated, medially grooved chilidium (Figure 7.1-3).

Shell parvicostellate and rugate, with 11-15 costae $(\mathrm{n}=8)$ in $5 \mathrm{~mm}$ at $10 \mathrm{~mm}$ from the dorsal umbo. Between 15 and 22 rugae on ventral disc; prominent on both discs and absent on trails.
Ventral interior (Figure 7.4-8) with small teeth, supported by short dental plates; muscle field subdiamond-shaped, raised anterolaterally and anteriorly on a low pseudospondylium; diductor scars large, fan-shaped, radially striated; adductor scars separating the diductors, raised on a prominent median ridge widening anteriorly and divided by a thin myophragm; base of the adductor ridge extends slightly anterior to the pseudospondylium 

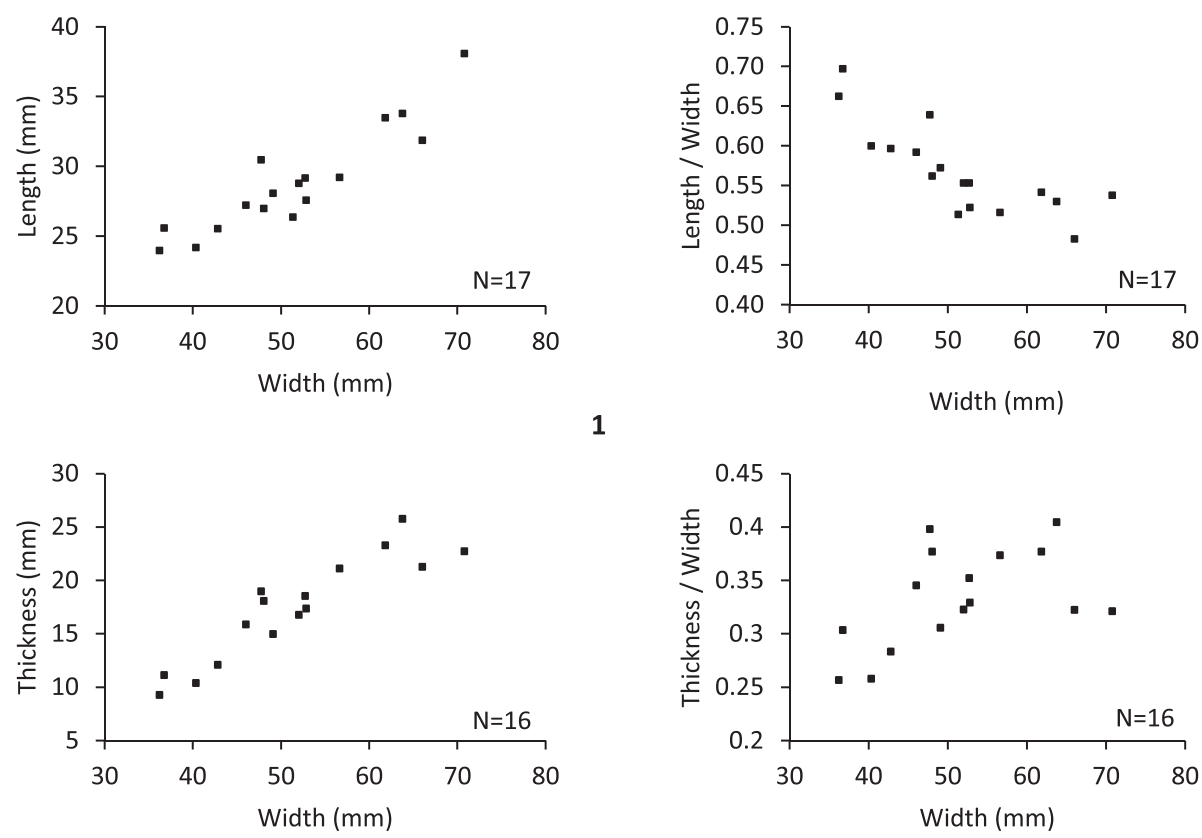

3
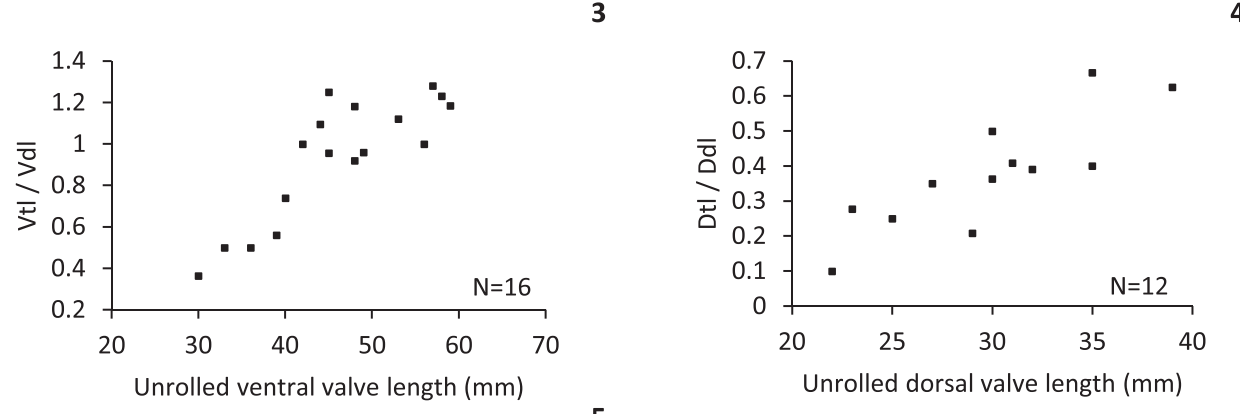

5

FIGURE 8. Scatter diagrams of Leptagonia franca sp. nov. N: number of specimens measured. 1, Relation between shell width and length. 2, Relation between shell width and shell length/shell width ratio. 3, Relation beween shell width and thickness. 4, Relation between shell width and shell thickness/shell witdth ratio. 5, Relation between unrolled ventral valve length and ratio between unrolled ventral trail length $(\mathrm{Vtl})$ and unrolled ventral disc length (Vdl). 6, Relation between unrolled dorsal valve length and ratio between unrolled dorsal trail length ( $\mathrm{Dtl}$ ) and unrolled dorsal disc length (Ddl).

as a rounded buttress onto valve floor; mantle canals not observed.

Dorsal interior (Figure 7.9-13) with stout, ventrolaterally oriented cardinal process lobes; muscle platform raised above the valve floor; cardinal process pit developed between the cardinal process lobes and the posterior margin of the muscle platform; posterior adductor scars more or less circular and separated by a median ridge terminating close to their anterior end, but variably developed among the examined material; anterior adductor scars markedly smaller and separated by a slender septum continuing anteriorly for a variable distance in front of the muscle platform and reaching its maximum height at the junction of the lateral ridges bounding the former, then decreasing rapidly towards the anterior margin; dental sockets deep, well-defined; socket plates diverging at an angle of $142-159$ degrees $(n=2)$; outer surface of the marginal ridge including numerous traces of mantle canals; tubercles abundant, but variably developed following the specimens (compare Figure 7.9 and 7.11).

Dimensions (Figure 8, Table 1). The number of specimens measured is rather low due to lack of well-preserved material. For this reason, the mean value is given without standard error. Nonetheless, the unrolled ventral trail length/unrolled ventral disc length and unrolled dorsal trail length/unrolled dorsal disc length ratios analysed here show that an interrelation is probable. 
TABLE 1. Measurements in mm of Leptagonia franca sp. nov. Abbreviations for tables 1-4: Ddl, unrolled length of dorsal disc; Dtl, unrolled length of dorsal trail; Hi, height of the ventral interarea; $L$, length of the shell; $T$, thickness of the shell; Vdl, unrolled length of ventral disc; Vtl, unrolled length of ventral trail; W, width of the shell; Wi, width of the ventral interarea.

\begin{tabular}{lccccccccccc}
\hline & $\mathbf{W}$ & $\mathbf{L}$ & $\mathbf{V d l}$ & $\mathbf{V t l}$ & $\mathbf{D d l}$ & $\mathbf{D t l}$ & $\mathbf{T}$ & $\mathbf{L} / \mathbf{W}$ & $\mathbf{T} / \mathbf{W}$ & $\mathbf{V t I /} \mathbf{V d l}$ & $\mathbf{D t} / \mathbf{D d l}$ \\
\hline N & 17 & 17 & 17 & 17 & 13 & 13 & 16 & 17 & 16 & 17 & 12 \\
Mean & 51.4 & 28.9 & 23.8 & 22.2 & 21.6 & 8.1 & 17.4 & 0.57 & 0.33 & 0.93 & 0.38 \\
MIN & 36.2 & 24 & 20 & 8 & 18 & 2 & 9.3 & 0.48 & 0.26 & 0.36 & 0.10 \\
MAX & 70.8 & 38.1 & 28 & 32 & 25 & 15 & 25.8 & 0.70 & 0.40 & 1.28 & 0.67 \\
\hline
\end{tabular}

Remarks. Until recently, Tournaisian leptaenines from Western Europe, but not only (see Bahrammanesh et al. (2011) for a non-exhaustive list of references), were identified as Leptagonia analoga (Phillips, 1836), whose lectotype was selected and illustrated by Brunton (1968) as subsequently did Brand (1972) and Cocks and Rong (2000). Phillips' species was described with great detail by Brunton (1968), Brand (1972), and Harper and Jeffrey (1996). As rightly proposed by Bassett and Bryant (2006), several features such as the outline of the muscular field could be used to discriminate all the forms identified as $L$. analoga, an opinion subsequently followed by Mottequin (2010) and Bahrammanesh et al. (2011). In order to concretise this point of view, a new large-sized species is here erected on the basis of the well-preserved material from the Tournai area, formerly illustrated by Demanet (1934). Leptagonia franca sp. nov. differs from $L$. analoga by its less elongate ventral disc, its more developed ventral trail, and its more inflated shell. Furthermore, its ornamentation is slightly coarser than in the latter and its ventral muscle field is subdiamond-shaped. Except the radial ornamentation, which is similar in both species, the same features plus a markedly distinct dorsal internal morphology are used to discriminate $L$. franca and $L$. caledonica Brand, 1972. Due to its distinctive external and internal features, $L$. franca cannot be confused with $L$. simorini (Sokolskaya in Sarytcheva et al., 1963) and L. smithi Brand, 1972. The new species differs from $L$. convexa (Weller, 1914) notably in its less elongate ventral disc and its more developed ventral trails. Leptagonia franca is clearly larger and has a coarser radial ornamentation than L. missouriensis Carter, 1968. Sanders (in Easton et al., 1958) erected Leptaena cooperi from the Represso Limestone of Sonora (Mexico), on the basis of a few incomplete specimens (see Carter, 1987), that he compared with the Belgian material illustrated by Demanet (1934). Indubitably, the internal morphology of both species is identical except some differences noted by Sanders (in Easton et al., 1958), such as the outline of the visceral disc (slightly more than semi-elliptical in $L$. franca vs. nearly completely elliptical in $L$. cooperi). Further material is however required to better describe the poorly known Mexican species.

Occurrence. Until now, Leptagonia franca is mainly known from the Tournai Formation in the eponymous area but also occurs in the Tournaisian succession of the Dinant Synclinorium, as evidenced by the specimens illustrated by Demanet (1934, pl. 5, figs. 10, 11) from the Hastarian Pont d'Arcole Formation. Its precise distribution in the Tournaisian succession would require a detailed survey of the complete Tournaisian succession, which is well beyond the scope of this paper. However, Demanet (1923, pl. 5, fig. 8) illustrated a ventral valve identified as Strophomena analoga from the Waulsort Formation at Sosoye in the Dinant sedimentation area (Figures 2-4). This specimen (RBINS a11747) characterized by its flat visceral disc and thin radial ornamentation (17 ribs per 5 $\mathrm{mm}$ at $10 \mathrm{~mm}$ from the umbo; 22 rugae) is re-illustrated herein (Figure 9.1-4) and left provisionally in open nomenclature due to the absence of additional material, and is thus identified as Leptagonia $\mathrm{sp}$. indet.

Leptagonia cf. caledonica Brand, 1972

Figures 4, 9.5-26, 10-11

\begin{tabular}{|c|c|c|}
\hline$p$ & 1843 & $\begin{array}{l}\text { Leptaena depressa Sowerby; de } \\
\text { Koninck, p. } 215 \text {, pl. } 12 \text {, figs. } 3,5 \text { (?), } 6 \text {. }\end{array}$ \\
\hline $\mathrm{p}$ & 1851 & Leptaena analoga; de Koninck, p. 653. \\
\hline $\mathrm{p}$ & 1868 & $\begin{array}{l}\text { Strophomena (Producta) analoga; } \\
\text { Dewalque, p. } 333 .\end{array}$ \\
\hline$p$ & 1881 & $\begin{array}{l}\text { Strophomenes (Producta) analoga; } \\
\text { Mourlon, p. } 47 .\end{array}$ \\
\hline$v$ & 1934 & $\begin{array}{l}\text { Leptaena sinuata de Koninck; } \\
\text { Demanet, p. } 74 \text {, pl. 6, figs. 6-7. }\end{array}$ \\
\hline * & 1972 & $\begin{array}{l}\text { Leptagonia caledonica sp. nov. Brand, } \\
\text { p. } 61 \text {, text-figs. } 1 \text { d, } 2-3 \text {, pl. } 9 \text {, figs. } 1-7 \text {. }\end{array}$ \\
\hline
\end{tabular}




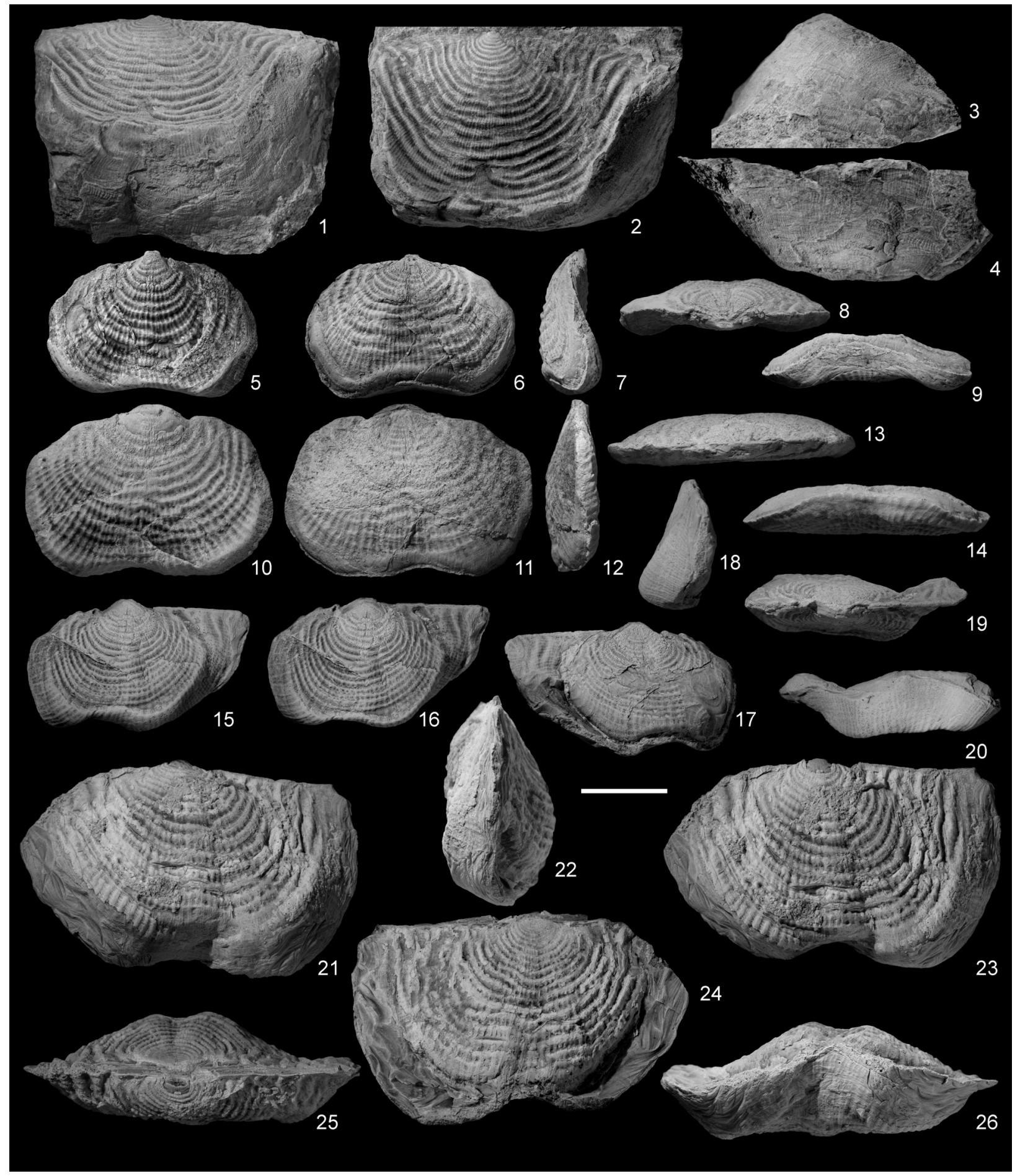

FIGURE 9. 1-4, Leptagonia sp. indet. from Sosoye, Waulsort Formation (Tournaisian, Ivorian), RBINS a11747, almost complete ventral valve in ventral, ventral (perpendicular to the disc), lateral and anterior views. 5-26, Leptagonia cf. caledonica Brand, 1972 from Visé, Visé Formation (Visean, Warnantian). 5-9, RBINS a5915, incomplete articulated specimen in ventral (perpendicular to the disc), dorsal, lateral, posterior, and anterior views. 10-14, RBINS a5914, incomplete articulated specimen in ventral (perpendicular to the disc), dorsal, lateral, posterior, and anterior views. 1520, ULg.PA. 2016.12.25/1, articulated specimen, almost complete, in ventral, ventral (perpendicular to the disc), dorsal, lateral, posterior and anterior views. 21-26, ULg.PA.2016.12.25/2, articulated specimen, almost complete, in ventral, lateral, ventral (perpendicular to the disc), dorsal, posterior, and anterior views. Scale bar equals $10 \mathrm{~mm}$. 


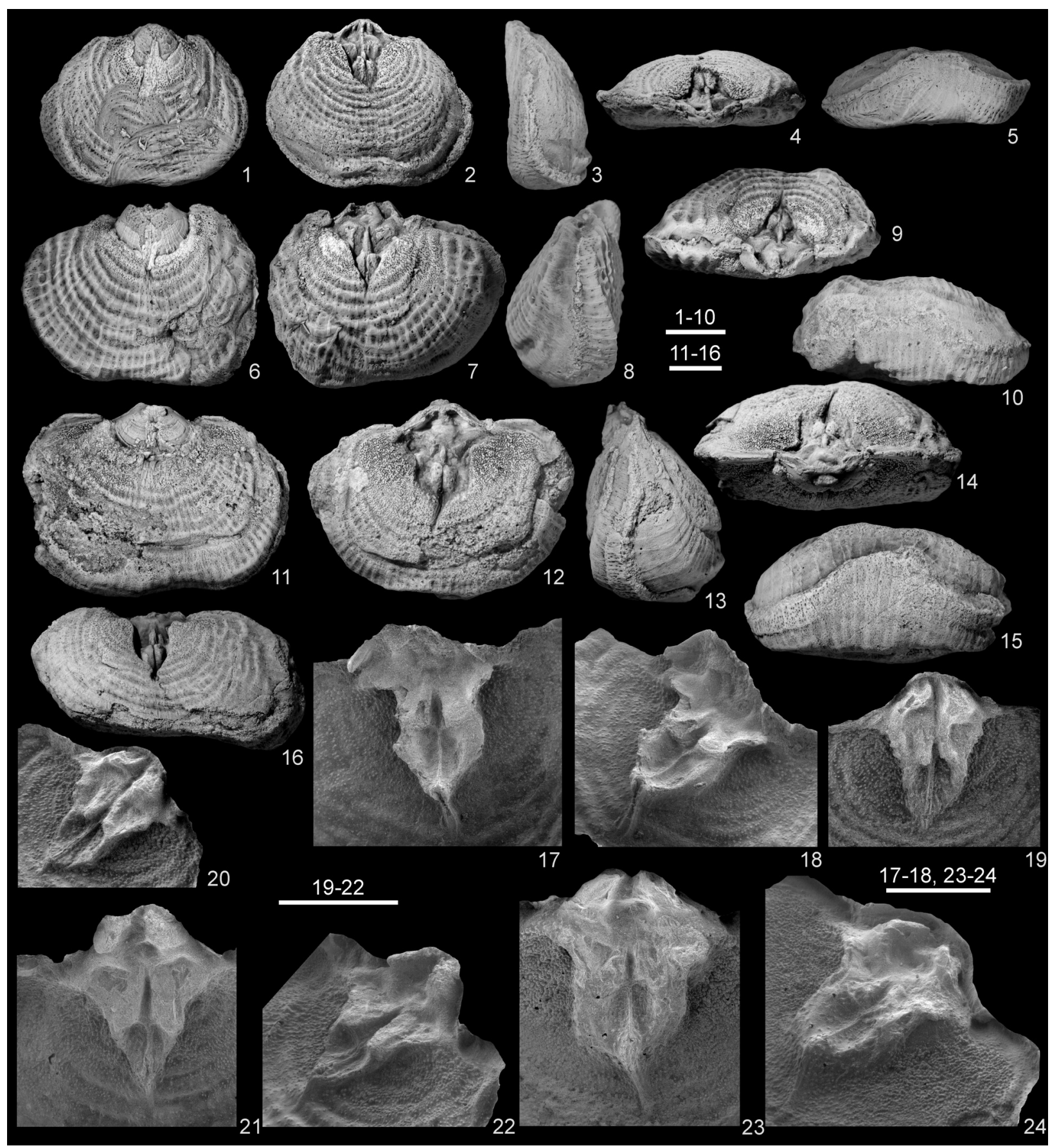

FIGURE 10. Leptagonia cf. caledonica Brand, 1972 from Visé, Visé Formation (Visean, Warnantian). 1-5, 19-20, ULg.PA.2016.12.25/3, internal mould in ventral, dorsal, lateral, posterior and anterior views, and detail (SEM) of the muscular platform (latex cast). 6-10, 21-22, ULg.PA.2016.12.25/4, internal mould in ventral, dorsal, lateral, posterior, and anterior views, and detail (SEM) of the muscular platform (latex cast). 11-15, 23-24, ULg.PA.2016.12.25/5, internal mould in ventral, dorsal, lateral, posterior, and anterior views, and detail (SEM) of the muscular platform (latex cast). 16-18, ULg.PA.2016.12.25/6, distorted internal mould in dorsal view and close-up (SEM) of the muscular platform (latex cast). Scale bars equal $5 \mathrm{~mm}$. 


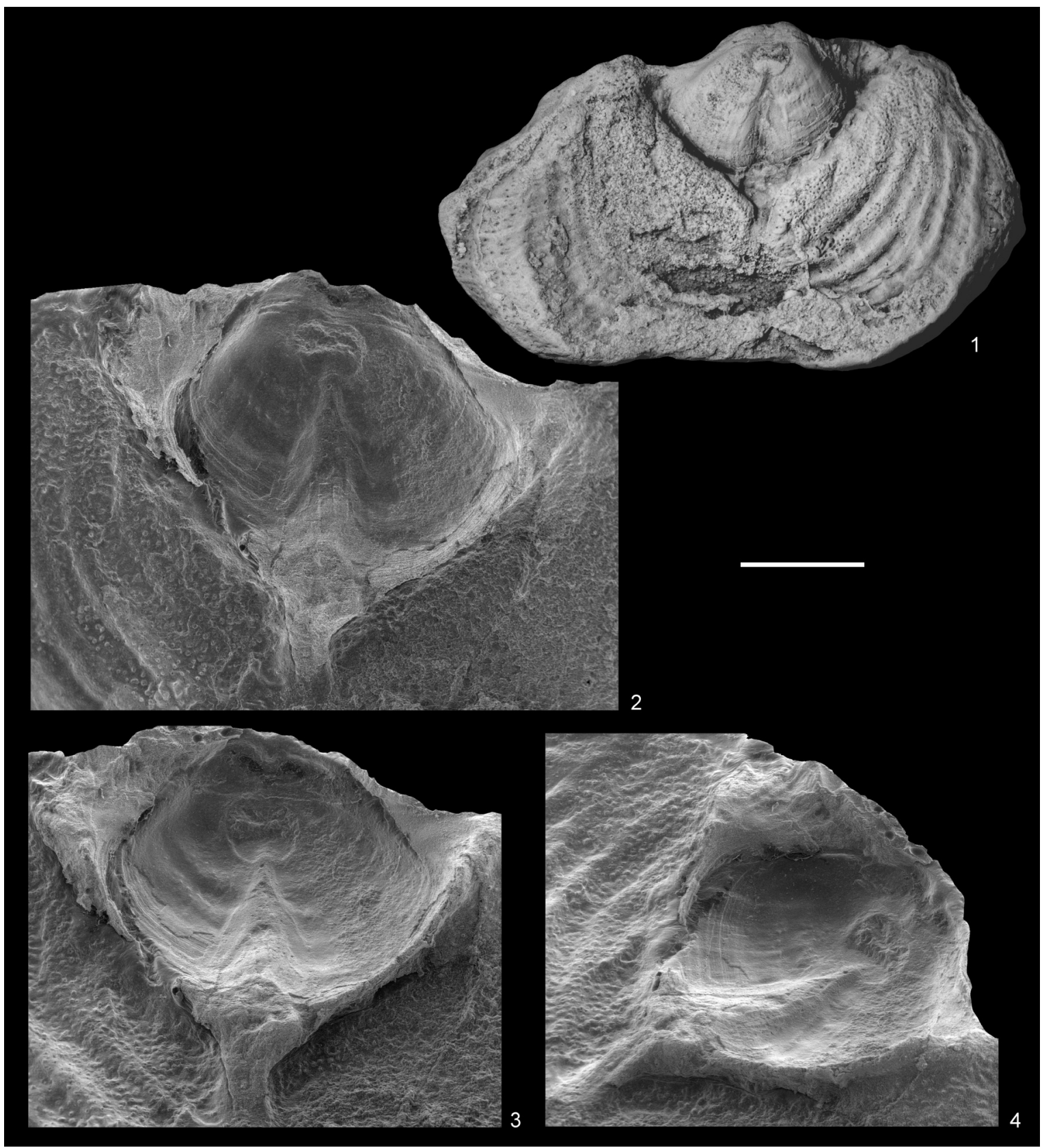

Leptagonia cf. caledonica Brand, 1972 from Visé, Visé Formation (Visean, Warnantian). 1-4, ULg.PA.2016.12.25/7, distorted, articulated internal mould in ventral view and detail of the latex mould of the muscular platform in three different views. Scale bar equals $5 \mathrm{~mm}(1), 2.5 \mathrm{~mm}(2-4)$.

Material. RBINS: besides the specimens RBINS a5914 (Figure 9.10-14)-5915 (Figure 9.5-9) illustrated by Demanet (1934 pl. 6, figs. 6-7), the studied material includes four ventral valves and 30 articulated specimens; ULg.PA: five ventral and two dorsal valves, and 54 articulated specimens. Due to the deficient preservation (e.g., trails and cardinal extremities broken), despite the great number of specimens available, it was not possible to perform statistics.

Description. Shell medium-sized (up to ca. 38.7 $\mathrm{mm}$ in width), subrectangular in outline with ears developed (exceptionally preserved), wider than long, concavo-convex, resupinate; widest at hinge line; trail development unknown (exceptionally and incompletely preserved); anterior margin emarginate. 
Ventral disc slightly convex in posterior and lateral view or flattened, roughly semi-circular to semi-elliptic in outline; posterior margin rectilinear, slightly broken by small umbo; sulcus round-bottomed, deep, only affecting the trail; interarea flat, low, apsacline; delthyrium closed apically by convex pseudodeltidium.

Dorsal disc convex, but with posterior part flattened in lateral view, roughly semi-circular to semielliptic in outline; ears flattened; in some specimens, presence of a shallow and poorly defined median depression originating in posterior part of the disc, reaching the geniculation; interarea linear, flat, catacline.

Shell parvicostellate and rugate, with $8-13$ costae $(n=10)$ in $5 \mathrm{~mm}$ at $10 \mathrm{~mm}$ from the umbones. Circa 13-16 $(n=3)$ relatively regular rugae on ventral disc (probably a little bit more as, in most of the specimens, the umbo is blunt); rugae prominent on both discs and absent on trails.

Ventral interior (Figures 10-1-15, 11) with large, subdiamond-shaped muscle field, raised anteriorly and anterolaterally on a low pseudospondylium; teeth not observed; diductor scars large, with poorly preserved radial striation; adductor scars separating the diductors, raised on a prominent median ridge widening anteriorly; base of the adductor ridge extending slightly anteriorly to the pseudospondylium as a rounded buttress onto valve floor; numerous tubercles concentrated in posterior part of the valve floor around the pseudospondylium, and also present on the rest of the valve, although less abundantly developed; mantle canals well developed (but insufficiently preserved for complete description).

Dorsal interior (Figure 10) with stout cardinal process lobes (cardinal process pit present directly antero-medial to them); muscle platform with anterior part strongly raised above valve floor; posterior adductor scars semi-circular, separated by deep median groove from which a median septum extends anteriorly; anterior portion of muscle platform consisting of two depressions separated by the septum reaching its maximum at the junction of the lateral ridges bounding these oval depressions; numerous tubercles concentrated in posterior part of the valve floor around the muscle platform and less abundantly developed on the rest of the valve,; mantle canals well developed (but insufficiently preserved for complete description).

Remarks. Demanet (1934, pl. 6, figs. 6, 7) illustrated two specimens from the Visean of Visé, which are re-illustrated here (Figure 9.5-14), that he assigned to the productide Sinuatella sinuata (de Koninck, 1851), which undoubtedly belong to Leptagonia by their external features (see discussion related to de Koninck's species of, e.g., MuirWood and Cooper [1960] and Brunton and Mundy [1988]). Brand (1972) tentatively assigned the specimen RBINS a5915 (Demanet, 1934, pl. 6, fig. 7 ) to his new species Leptagonia smithi. After examination of numerous specimens, it appears that the material from Visé cannot be assigned to L. smithi Brand, 1972 as it is characterized by the development of ears (rarely preserved in the investigated material), the largeness of the tuberculate areas and especially by the markedly greater development of the dorsal muscle platform (compare with Brand, 1972, text-fig. 3, pl. 11, fig. 6). From the viewpoint of the internal and external morphology, the Belgian material is comparable to L. caledonica, except its ornamentation, which is coarser: $8-13$ versus $10-16$ costae in $5 \mathrm{~mm}$ at 10 $\mathrm{mm}$ from the umbones according to Brand (1972). Nonetheless, although the available material is abundant, its relatively poor state of preservation (most of the specimens are devoid of trails and ears) does not allow a more confident identification; that is why it is doubtfully assigned to Brand's (1972) species.

Occurrence. The Belgian material originates from Visé (Visé Formation, Visean), whereas Leptagonia caledonica seems to be confined to the British Visean and Serpukhovian according to Brand (1972, 2011) and Brunton and Tilsley (1991).

Order ORTHOTETIDA Waagen, 1884 Suborder ORTHOTETIDINA Waagen, 1884 Superfamily ORTHOTETOIDEA Waagen, 1884

Family PULSIIDAE Cooper and Grant, 1974

Genus SCHELLWIENELLA Thomas, 1910

Type species. Spirifera crenistria Phillips, 1836, from the Visean Pendleside Group of Bowland, Yorkshire, England.

Schellwienella radialiformis Demanet, 1934 Figures 4, 12-14

\begin{tabular}{|c|c|c|}
\hline $\mathrm{V}^{*}$ & 1934 & $\begin{array}{l}\text { Schellwienella aspis mut. radialiformis } \\
\text { nov. mut. Demanet, p. } 85 \text {, pl. } 7 \text {, figs. } 6- \\
12 .\end{array}$ \\
\hline v & 1934 & $\begin{array}{l}\text { Schellwienella sp.; Demanet, p. } 81 \text {, } \\
\text { text-fig. } 15 \text {, pl. } 7 \text {, fig. } 3 \text {. }\end{array}$ \\
\hline non & 1954 & $\begin{array}{l}\text { Schellwienella (subgen. nov. } \\
\text { Carlospina) radialiformis Demanet; } \\
\text { Reed, p. 183, pl. } 3 \text {, fig. } 21 \text {. }\end{array}$ \\
\hline v & 1958 & $\begin{array}{l}\text { Schellwienella aspis radialiformis } \\
\text { Demanet; Demanet, p. } 126 .\end{array}$ \\
\hline & 1969 & $\begin{array}{l}\text { Schellwienella aspis radialiformis } \\
\text { Demanet; Mortelmans, p. } 31 .\end{array}$ \\
\hline
\end{tabular}




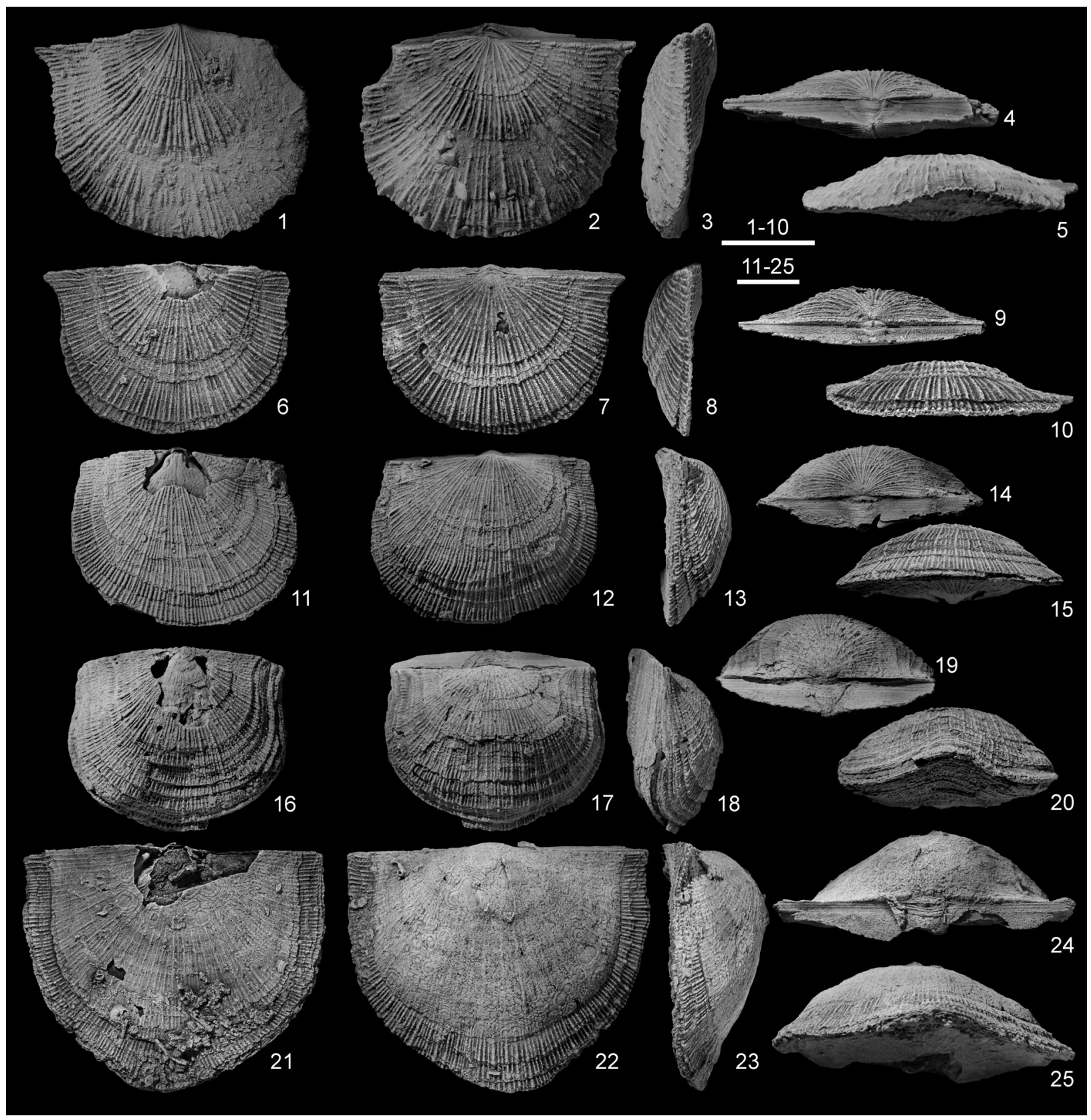

FIGURE 12. Schellwienella radialiformis Demanet, 1934 from the Tournai area, Tournai Formation (Tournaisian). 1-5, RBINS a5924, articulated specimen, almost complete, in ventral, dorsal, lateral, posterior, and anterior views. 6-10, RBINS a5928, articulated specimen, almost complete, in ventral, dorsal, lateral, posterior, and anterior views. 11-15, RBINS a5929, articulated specimen, almost complete, in ventral, dorsal, lateral, posterior and anterior views. 16-20, RBINS a5930 (lectotype), articulated specimen, almost complete, in ventral, dorsal, lateral, posterior, and anterior views. 21-25, RBINS a5926, almost complete articulated specimen (with a microconchid attached to the ventral valve, close to the anterior margin) in ventral, dorsal, lateral, posterior, and anterior views. Scale bars equal $10 \mathrm{~mm}$.

Type material. Demanet (1934) considered all the illustrated specimens as paratypes according to the legend of his plate 7 . The articulated specimen RBINS a5930 (Demanet, 1934, pl. 7, fig. 12; Figure 12.16-20) is selected here as the lectotype whereas the other RBINS specimens illustrated by
Demanet (1934, pl. 7, figs. 6-11), namely a5924 (Figures 12.1-5, 13.11-12), a5925 (Figure 13.1417), a5926 (Figure 12.21-25), a5927 (Figure 13.15), a5928 (Figures 12.6-10, 13.13) and a5929 (Figure 12.11-15), are considered as paralectotypes and fully illustrated herein. 


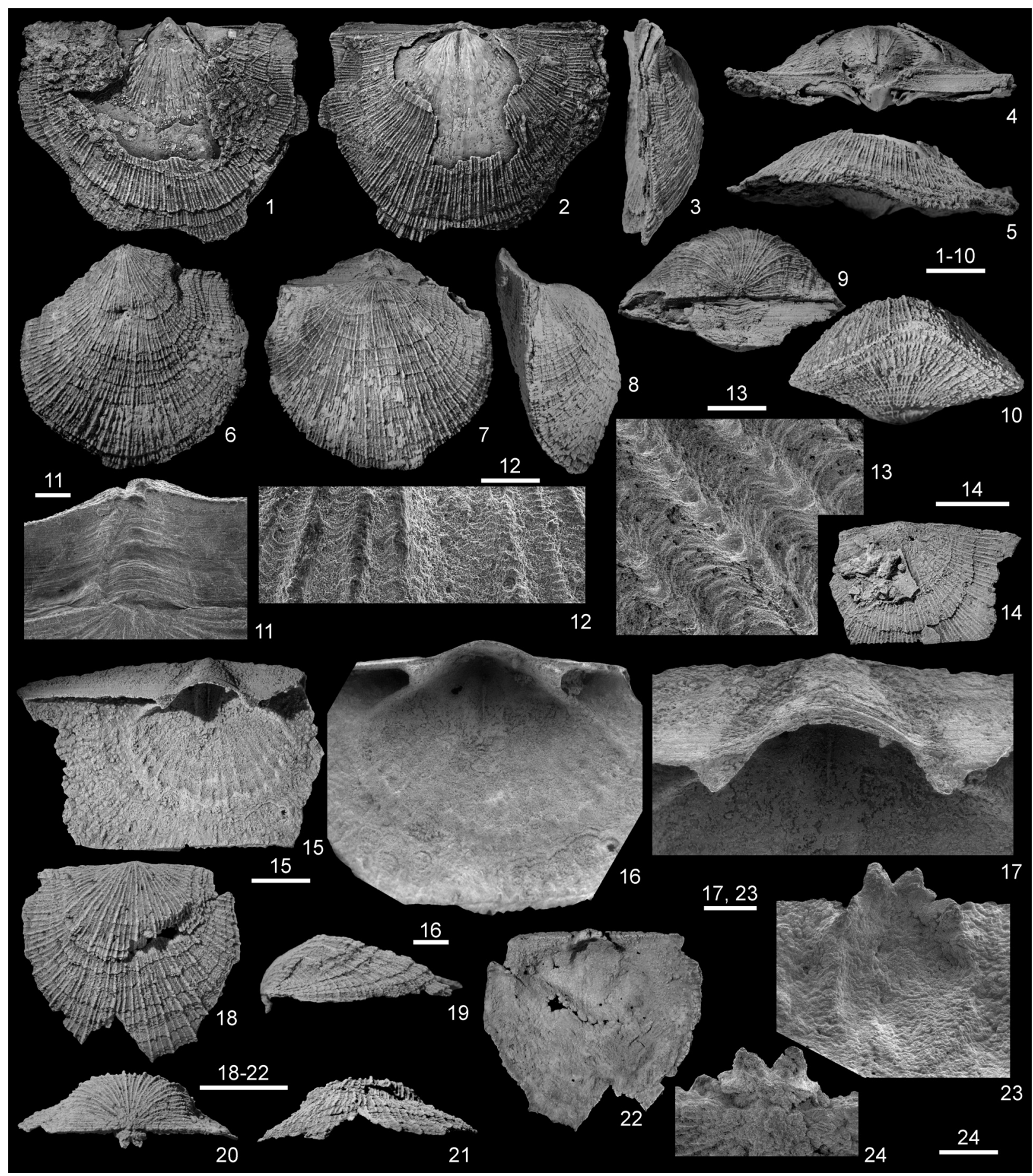

FIGURE 13. Schellwienella radialiformis Demanet, 1934 from the Tournai area, Tournai Formation (Tournaisian). 1-5, RBINS a5927, articulated specimen, almost complete, in ventral, dorsal, lateral, posterior and anterior views. 6-10, RBINS a13105, articulated specimen, almost complete, in ventral, dorsal, lateral, posterior, and anterior views. 11-12, RBINS a5924, detail (SEM) of the pseudodeltidium and of the koskinoid perforations penetrating in the umbonal part of the ventral valve. 13, RBINS a5928, detail of the microornament on dorsal valve (SEM). 14-17, RBINS a5925, incomplete ventral valve in external and internal views and detail (SEM) of the posterior internal and external morphology. 18-24, RBINS a13106, almost complete dorsal valve in dorsal, lateral, posterior, and internal views and detail (SEM) of the posterior morphology (cardinal process). Scale bars equal $10 \mathrm{~mm}(1-10,14,18-22), 1 \mathrm{~mm}(11)$, $0.25 \mathrm{~mm}$ (12), $0.5 \mathrm{~mm}$ (13), $2 \mathrm{~mm}(17,23), 2.5 \mathrm{~mm}(24), 5 \mathrm{~mm}$ (15). 


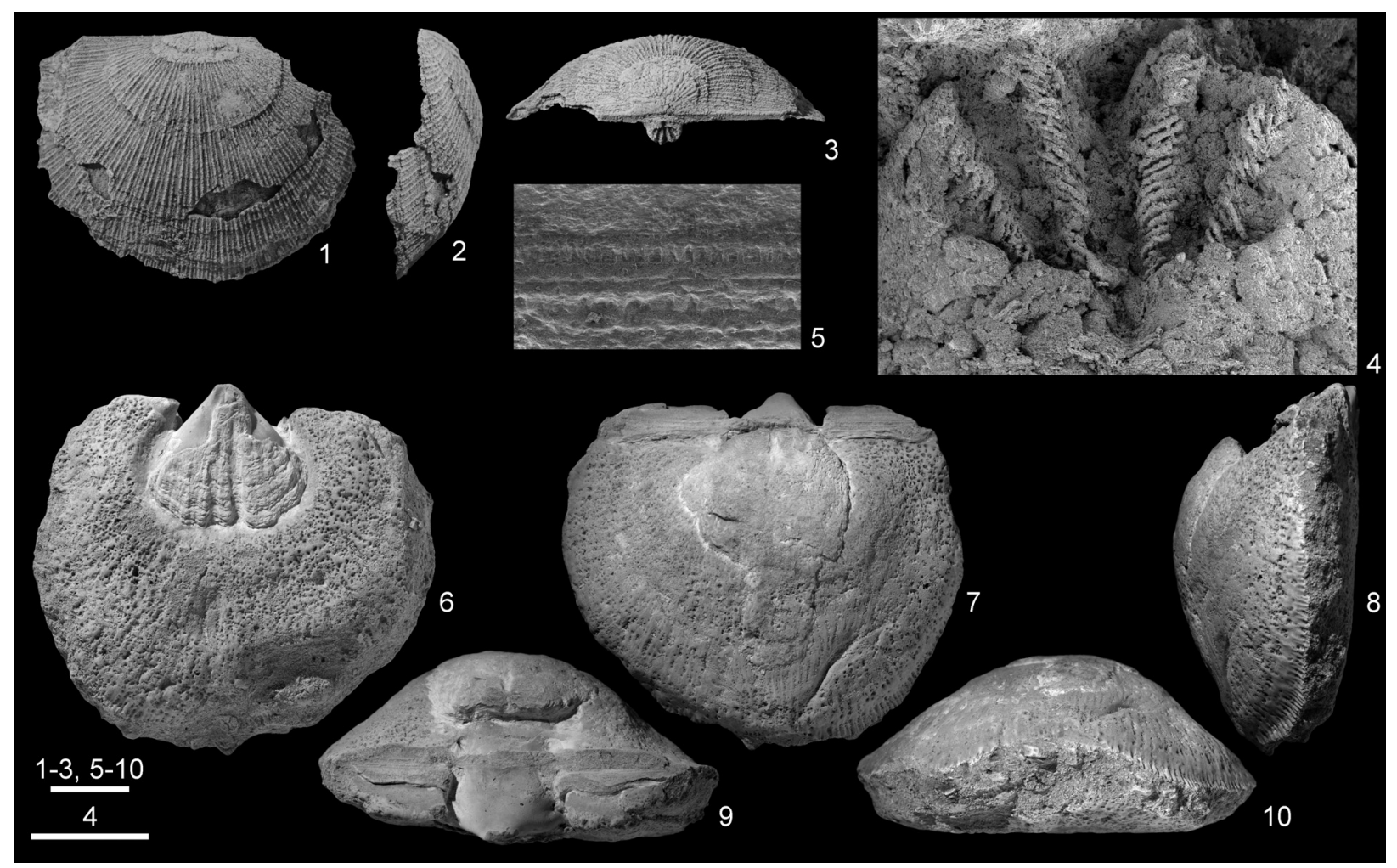

FIGURE 14. Schellwienella radialiformis Demanet, 1934 from the Tournai area, Tournai Formation (Tournaisian). 1-4, RBINS a13107, almost complete dorsal valve in dorsal, lateral and posterior views and detail of the chilidium and cardinal process lobes. 5-10, RBINS a5921, articulated internal mould with shelly remains in ventral, dorsal, lateral, posterior and anterior views and close-up of the ventral interarea (5). Scale bars equal $10 \mathrm{~mm}(1-2,4-6), 1 \mathrm{~mm}(4,5)$.

Additional material. Two ventral and two dorsal valves, and ten articulated specimens.

Description. Shell large-sized (up to ca. $51 \mathrm{~mm}$ in width), wider than long, quadrate to subquadrate in outline, slightly mucronate, strongly dorsibiconvex to resupinate, widest at hinge (juveniles) or anteriorly to it (adults); anterior margin rounded; anterior commissure rectimarginate to slightly uniplicate.

Ventral valve posteriorly convex then becoming concave anteriorly (resupinate shell) or rarely slightly convex (dorsibiconvex shell); umbo small; interarea triangular, high, flat to slightly concave, catacline to anacline; pseudodeltidium convex and perideltidium flat (Figure 13.11, 13.17); median depression rarely developed and occurring in anterior part of valve; koskinoid perforations developed in umbonal area (Figure 13.12).

Dorsal valve convex with maximum height located at midvalve or posteriorly and then decreasing rapidly towards anterior commissure; posterolateral areas flattened in posterior view; interarea linear, flat, anacline; chilidium convex.

Ornamentation parvicostellate; in some specimens, costellae can thicken so much that they become as large as the costae at the anterior margin; at front, 7-11 costae and costellae per $5 \mathrm{~mm}$; growth lamellae numerous irregularly spaced, more crowded near margins in adults; filae fine, forming minute ridges across the crests of the costae and costellae (ca. 14 per $1 \mathrm{~mm}$ ) (Figure 13.1213).

Ventral interior (Figures 12.11, 13.1, 13.15-17) with large and deep delthyrial cavity; lateral apical cavities not filled in; dental plates strongly divergent anteriorly (78-93 degrees $[n=4]$ ), enclosing the posterior half of the muscle field; teeth large; muscle field slightly impressed, flabellate, slightly wider than long, extending up to 38 percent of the valve length; adductor muscles bounded laterally by two very low slightly curved ridges (but not fusing) and divided by a slender and low myophragm not extending beyond the distal extremities of the lateral ridges; diductor field large, flabellate, entirely enclosing the adductor field and anteriorly limited by a low ridge.

Dorsal interior (Figures 13.2, 13.20, 13.22-24, 14.3-4) with socket ridges divergent at 90 degrees $(n=1$ !) from another and only slightly curved, fused 
to cardinal process lobes; sockets deep, round-bottomed and laterally bounded by valve floor; cardinal process lobes high, posteroventrally oriented, grooved posteriorly; muscle field longer than wide, extending up to 35 percent of the unrolled length of the valve; adductor scars oval, posteriorly defined by plates extending from socket ridges, and clearly separated by a median ridge.

Remarks. Demanet (1934) considered the specimens from Tournai as a mutation of Schellwienella aspis Smyth (1930) from the Tournaisian Hook Head Formation of southern Ireland (see Bassett and Bryant, 2006; Mottequin, 2010). According to the article 45.6.4 of the International Code of Zoological Nomenclature (1999), the epithet radialiformis has to be considered as of subspecific rank in Demanet's (1934) publication. The species was promoted to a specific level by Reed (1954) and included in Schellwienella (Carlospina) Reed, 1954 , a subgenus considered as a synonym of Schellwienella by Williams (1965) and Williams and Brunton (2000). Schellwienella radialiformis Demanet, 1934 differs from S. radialis (Phillips, 1836), as revised by Brunton (1968), by its less strongly parvicostellate ornamentation (the primary costae are generally less pronounced), and its ventral muscle field has a markedly different outline (compare with Davidson 1861, pl. 25, fig. 17). Schellwienella radialiformis differs from $S$. aspis Smyth, 1930 by its parvicostellate ornamentation and its undulose to uniplicate anterior commissure. Demanet's (1934) species is distinguished from $S$. cheuma Bassett and Bryant, 2006 notably in its parviclostellate ornamentation, its more convex pseudodeltidium, and its subrounded ventral muscle field.

Demanet (1934, text-fig. 15, pl. 7, fig. 3) illustrated the specimen RBINS a5921 that he considered as a 'forme spéciale dérivant de Schellwienella' as it displays some structures observed on the ventral interarea which he interpreted as hinge denticles (Figure 14.5). These structures, resulting from the intersection of the vertical and horizontal ornamentation of the ventral interarea, simply result from repetitive interruptions of the shell growth.

Occurrence. Schellwienella radialiformis is known from the Tournai Formation in the eponymous area.

\section{Schellwienella ornata Demanet, 1934}

Figures 4, 15

V* $1934 \quad$ Schellwienella ornata nov. sp. Demanet, p. 83 , text-fig. 16 , pl. 7 , figs. $4-5$.
Type material. The complete internal mould (RBINS a5922) illustrated by Demanet (1934, pl. 7, fig. 4) is selected herein as the lectotype (Figure 15.1-8) whereas the specimen (RBINS a5923) figured by Demanet (1934, pl. 7, fig. 5, text-fig. 16) and of which the ventral umbo has been sectioned by him, is selected as the paralectotype (Figure 15.9-14). Both specimens were considered as paratypes by Demanet (1934). Until now, although Demanet (1934, p. 84) reported other specimens assigned to his new species, only the types have been recovered.

Description. Shell medium-sized (up to $41.8 \mathrm{~mm}$ in width), markedly ventribiconvex, subquadrate in outline, with maximum width near midlength; hinge line clearly shorter than maximum width; cardinal margins rounded; anterior margin straight or depressed; anterior margin rectimarginate or vaguely undulose.

Ventral valve moderately inflated, with flanks sloping moderately towards lateral commissure; umbo not prominent (at least in internal mould) beak straight; interarea irregularly triangular (deformation due to cementation on an organic or inorganic substrate), high, flat, apsacline; perideltidium flat; pseudodeltidium narrow, strongly convex; cementation cicatrix only preserved in lectotype.

Dorsal valve slightly convex, with maximum height near mid-valve then slightly decreasing towards anterior margin; interarea linear, flat, anacline; shallow median depression originating near posterior margin developed in one specimen.

Ornamentation parvicostellate (Figure 15.14); costellae increasing by intercalation, 6-7 costae per $5 \mathrm{~mm}$ near front separated from each other 5-6 costellae; growth varices developed; filae absent.

Ventral interior (Figure 15.1-2, 5, 7) with thin dental plates diverging at an angle of 35-37 degrees; teeth small; muscle field not excavated, obscure.

Dorsal interior (Figure 15.3, 7-8) with posteriorly grooved cardinal process lobes; socket ridges recurved, widely divergent; muscle field slightly excavated, obscure but well-defined posteriorly by lateral ridges extending from the socket ridges.

Remarks. Despite the availability of the type material illustrated by Demanet (1934), Schellwienella ornata remains incompletely known as its intraspecific variability cannot be investigated. Its main features are the parvicostellate ornamentation devoid of filae and the slightly divergent dental plates, which are not without evocating the genus Pulsia Ivanov, 1925, but the latter is characterized by parallel dental plates whereas Schellwienella encom- 


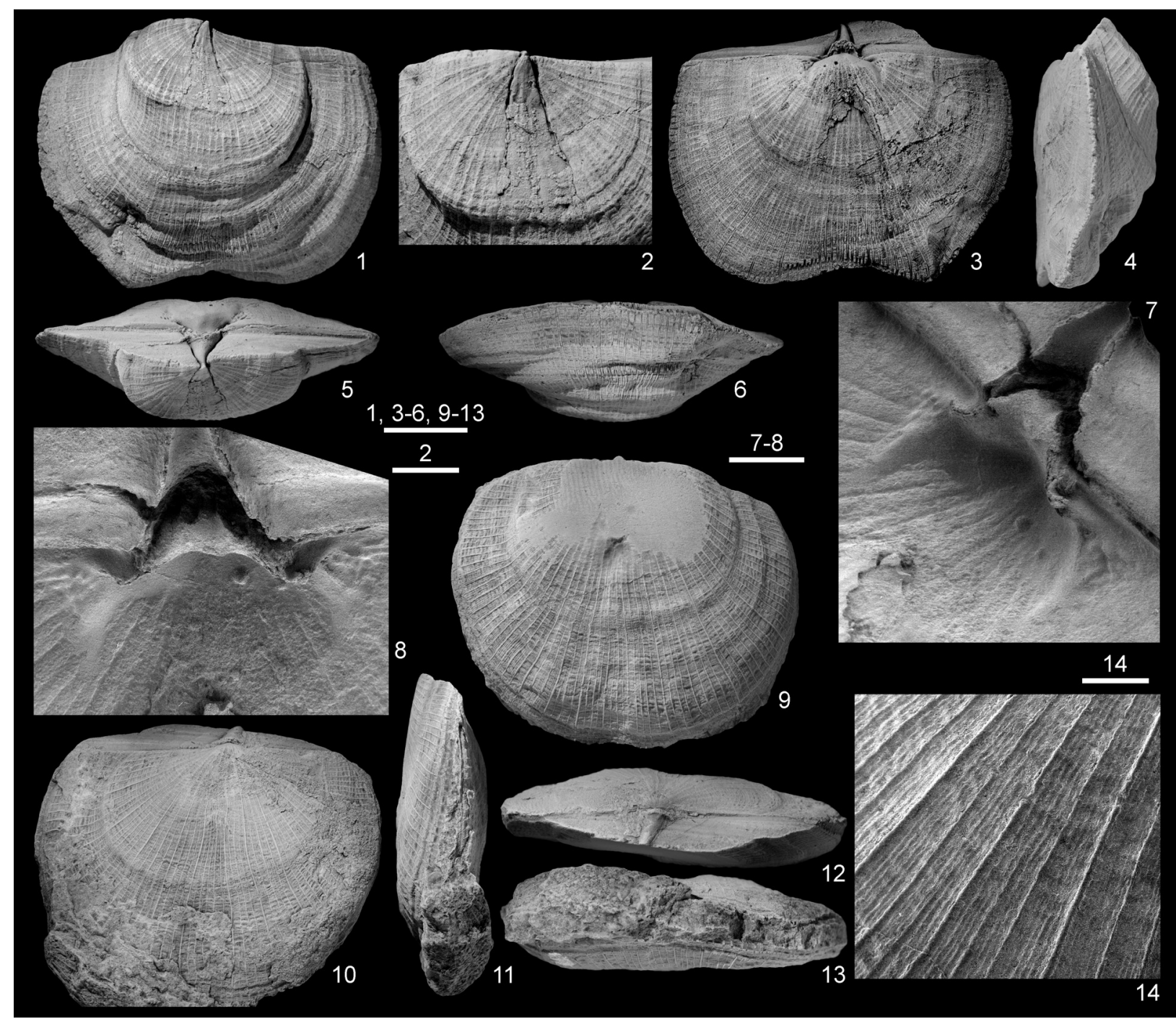

FIGURE 15. Schellwienella ornata Demanet, 1934 from Visé, Visé Formation (Visean, Warnantian). 1-8, RBINS a5922 (lectotype), articulated internal mould in ventral, enlarged ventral (showing the extent of the traces left by the dissolved dental plates), dorsal, lateral, posterior, and anterior views, and internal views of a latex cast (SEM) showing the internal morphology of the posterior part of the specimen (7-8). 9-14, RBINS a5923 (paralectotype), articulated specimen (partly sectioned, probably by Demanet) in ventral, dorsal, lateral, posterior, and anterior views, and close-up (SEM) of the parvicostellate ornamentation in the central part of the dorsal valve. Scale bars equal $10 \mathrm{~mm}$ (1, 3-6, 9-13), $5 \mathrm{~mm}(2), 2.5 \mathrm{~mm}(7-8), 1.25 \mathrm{~mm}(14)$.

passes species with dental plates variably divergent from hinge line (Mclntosh, 1974). Schellwienella ornata differs from S. crenistria (Phillips, 1836) by the absence of filae, its quadro-rounded outline, and its narrow hinge line (the maximum width is near midlength vs. close to the hinge). According to Demanet (1934), his species is very similar to Orthis cylindrica M'Coy, 1844 from the Visean (Brigantian) of Castle Espie (Comber, Co. Down, Ireland). M'Coy's (1844, pl. 22, fig. 1) original specimen was illustrated by Davidson (1861, pl. 27, fig. 9), and this species was considered as probable Schellwienella representative by Thomas (1910, p. 127). Furthermore, Orthis cylindrica was considered as a variety of Schellwienella crenistria (Phillips, 1836) by Davidson (1861, p. 128; 1880, p. 290). Note that the specimens from the Serpukhovian of Scotland (base of the Millstone Grit Series) identified as Streptorhynchus crenistria var. cylindrica M'Coy and illustrated by Davidson (1880: pl. 37, figs. 6-7) have been assigned to Schellwienella rotundata Thomas, 1910 and Orthothetina cf. thomasi (Sokolskaya in Sarytcheva and Sokolskaya, 1952) by Mclntosh (1974: 204, 209), 


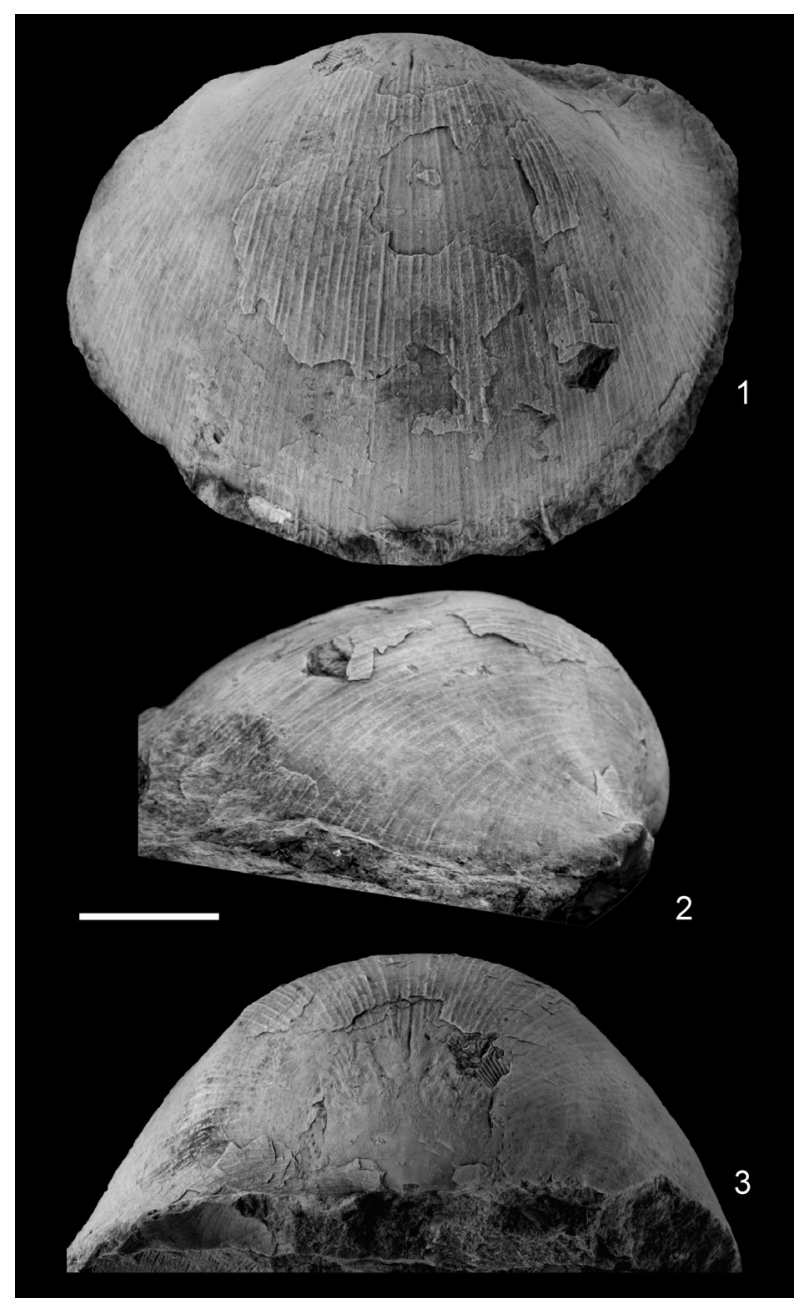

FIGURE 16. Schellwienella cylindrica (M'Coy, 1844), from the Visean (Brigantian) of Castle Espie (Comber, Co. Down, Ireland). 1-3, NMING:F6267 (lectotype), almost complete dorsal valve in dorsal, lateral, and posterior views. Scale bar equals $10 \mathrm{~mm}$.

respectively. The only specimen illustrated by M'Coy (1844) cannot be found in the Griffith collections curated at the National Museum of Ireland, but there is a dorsal valve (NMING:F6267) (Figure 16) from the same locality which matches M'Coy's description; thus it is herein selected as lectotype for nomenclatorial purposes. The type specimens of Demanet's (1934) species have a markedly less convex dorsal valve and a thinner radial ornamentation. Thomas (1971) noted the similarities between the ornamentation of $S$. ornata and those of $S$. reprinki Sokolskaya (in Sarytcheva and Sokolskaya, 1952) (see also Sokolskaya, 1954) and S. weaberensis Thomas, 1971.

Occurrence. The type specimens were recovered from the Visé Formation at Visé according to
Demanet (1934), who also reported the species in the 'calcschistes de Warnant' in the Condroz sedimentation area, corresponding now to the Upper Member of the Anhée Formation (see Poty et al., 2002) (late Warnantian; Figure 4). However, Demanet (1958) did not report this species anymore within the Anhée Formation.

Family SCHUCHERTELLIDAE Williams, 1953 Subfamily SCHUCHERTELLINAE Williams, 1953 Genus SERRATOCRISTA Brunton, 1968

Type species. Serratocrista fistulosa Brunton, 1968; from the Visean (Asbian) of County Fermanagh (Ireland).

\section{Serratocrista scaldisensis sp. nov.}

Figures 4, 17-19, Table 2

zoobank.org/29F8E248-E952-42A5-9307-2A3931FC86CE

Etymology. From Scaldis (Latin: Escaut), in reference to the Escaut river on the banks of which the town of Tournai is settled.

Holotype. RBINS a13110 (Figures 17.12-16, 18.1, 18.6).

Paratypes. RBINS: a13108 (Figure 17.1-6), a13109 (Figure 17.7-11), a13111 (Figures 17.1721, 18.2-3, 18.19-21), a13112 (Figure 17.22-25), a13113 (Figure 18.4-5), a13114 (Figure 18.7-13), a13115 (Figure 18.14-18), and a13116 (Figure 19). Additional material. RBINS: four articulated specimens.

Type locality. Tournai area (southwestern Belgium) (Figures 2-3).

Type stratum. Tournai Formation, Tournaisian (Figure 4).

Diagnosis. A small-sized (ca. $15 \mathrm{~mm}$ in width) Serratocrista species of, wider than long, planoconvex in profile and subquadrate-rounded in outline, with maximum width near midlength. Ornamentation multicostellate, 12 to 15 costellae per $5 \mathrm{~mm}$ at anterior margin with costellae increasing essentially by intercalations. Dorsal muscle field impressed, obscure, poorly delimited anteriorly, extending up to 40 percent of the valve length; myophragm low.

Description. Shell small-sized (up to $15.6 \mathrm{~mm}$ in width), wider than long, subquadrate in outline, plano-convex; maximum width near midlength; hinge line shorter than maximal width; cardinal angles and anterior margin rounded; anterior commissure rectimarginate to slightly unisulcate. Shell extropunctate with extropunctae arranged radially along the axis of the costellae (Figure 18.2-3).

Ventral valve convex, with maximum height near posterior margin, then decreasing progressively towards anterior commissure; umbo small but prominent, umbonal region sometimes 


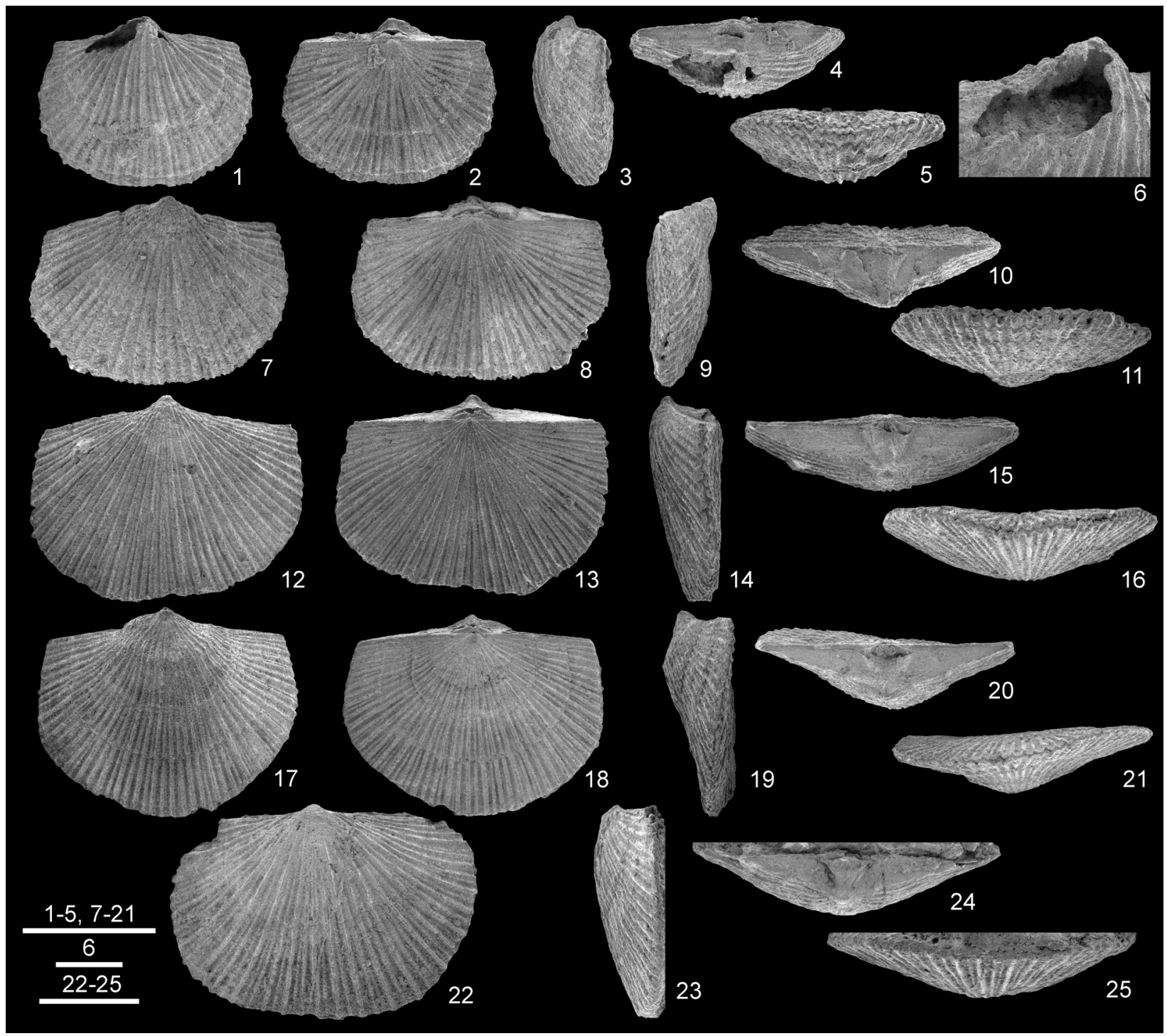

FIGURE 17. Serratocrista scaldisensis sp. nov. from the Tournai area, Tournai Formation (Tournaisian) (all SEM). 1-6, RBINS a13108, articulated specimen, almost complete, in ventral, dorsal, lateral, posterior, and anterior views, and close-up of the umbo showing the absence of dental plates. 7-11, RBINS a13109, articulated specimen in ventral, dorsal, lateral, posterior, and anterior views. 12-16, RBINS 13110 (holotype), articulated specimen in ventral, dorsal, lateral, posterior, and anterior views. 17-21, RBINS a13111, articulated specimen in ventral, dorsal, lateral, posterior, and anterior views. 22-25, RBINS a13112, almost complete ventral valve in ventral, lateral, posterior, and anterior views. Scale bars equal $1 \mathrm{~mm}(6), 5 \mathrm{~mm}(1-5,7-25)$.

deformed (flattened) by cementation with koskinoid perforations (Figure 18.19-21), which are also present on the interarea); beak not curved; interarea triangular, low, cata-apsacline to apsacline, flat to slightly concave; pseudodeltidium strongly convex (Figure 18.1-3).

Dorsal valve flat with, in some specimens, development of a shallow median depression; chilidium small, convex, medianly grooved; interarea linear, anacline, flat.
Ornamentation multicostellate (12-15 costellae per $5 \mathrm{~mm}$ at anterior margin) with costellae increasing essentially by intercalations, more rarely by bifurcations; ca. 10 concentric microlines per 1 $\mathrm{mm}$, thickened at irregular interval (growth varices), and forming protuberances on rib crests (Figure 18.6).

Ventral interior poorly known (Figures 17.6, 19.1-4); teeth small, rounded, unsupported; muscle field not observed. 


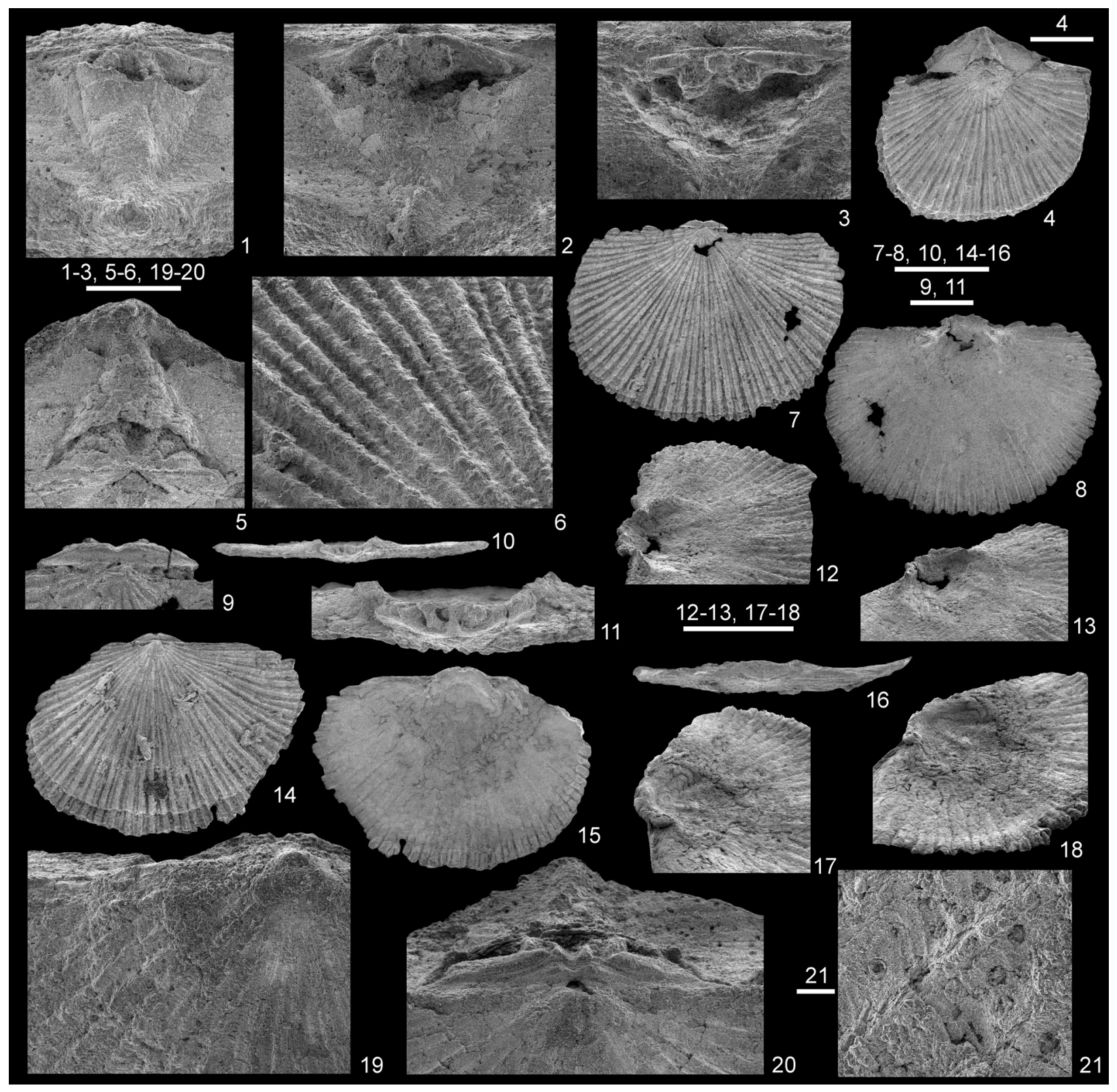

FIGURE 18. Serratocrista scaldisensis sp. nov. from the Tournai area, Tournai Formation (Tournaisian). 1, 6, RBINS a13110 (holotype), close-up of the strongly convex pseudodeltidium, and detail of the microornament (central part of the dorsal valve). 2-3, 19-21, RBINS a13111, detail of the strongly convex pseudodeltidium and of the cardinal process, and close-up of the koskinoid perforations developed in the ventral umbonal area and on the interarea. 4-5, RBINS a13113, incomplete articulated specimen in dorsal view and close-up of the posteriorly grooved lobes of the cardinal process. 7-13, RBINS a13114, dorsal valve in external, internal and posterior (10) views, detail of the chilidium (9), the cardinal process (11), and oblique views of the internal posterior region (12-13). 14-18, RBINS a13115, almost complete dorsal valve in external, internal and posterior views and oblique views of the internal posterior region. Scale bars equal $1 \mathrm{~mm}(1-3,5-6,9,11$, and 19-20), $2.5 \mathrm{~mm}$ (4), $5 \mathrm{~mm}(7-8,10,14-16,12-13$, and 17-18), 0.1 $\mathrm{mm}(21)$.

Dorsal interior (Figure 18.1-3, 8, 12-13, 15-18) with cardinal process lobes small, posteriorly grooved; muscle field impressed, obscure, poorly delimited anteriorly, extending up to 40 percent of the valve length; myophragm low (observed in one specimen); socket ridges diverging from the hinge line at an angle of 26-48 degrees $(n=2)$. 


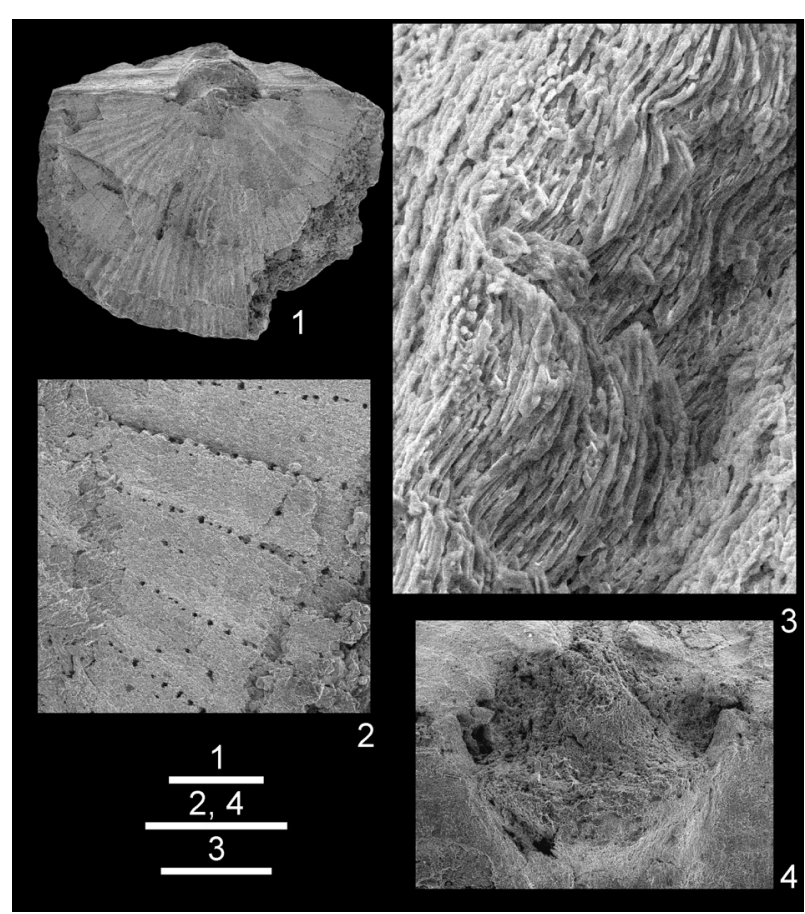

FIGURE 19. Serratocrista scaldisensis sp. nov. from the Tournai area, Tournai Formation (Tournaisian). 1-4, RBINS a13116, articulated specimen, incomplete, in dorsal view (1) with detail of the extropunctae arranged radially along the axis of the costellae $(2,3)$, and of the basal part of the pseudodeltidium and of the teeth (4). Scale bars equal $2 \mathrm{~mm}(1), 0.5 \mathrm{~mm}(2), 0.025 \mathrm{~mm}(3), 1$ $\mathrm{mm}(4)$.

\section{Dimensions (Table 2)}

Remarks. The ornamentation and the cardinalia of this limited material suggest an assignment to Serratocrista, although its type species is devoid of dorsal myophragm, which has been observed in ours. In their discussion of the original diagnosis given by Brunton (1968), Roberts (1971) and Mclntosh (1974) reported the occasional occurrence of a dorsal myophragm in their material assigned to

TABLE 2. Measurements in $\mathrm{mm}$ of Serratocrista scaldisensis sp. nov. Abbreviations: see Table 1.

\begin{tabular}{cccccc}
\hline RBINS & W & L & T & Hi & Wi \\
\hline a13108 & 8.1 & 6.5 & 2.9 & 1.2 & 7.2 \\
a13109 & 9.8 & 7.1 & 2.4 & 2.2 & 8.8 \\
a13110 & 10.4 & 7.7 & 2.7 & 1.8 & 9.6 \\
a13111 & 13.1 & 9.8 & 3.3 & 2.2 & 12.1 \\
a13112 & 15.6 & 10.8 & $/$ & 2.0 & $/$ \\
a13117 & 9.4 & 8 & 3.2 & 2.3 & 7.6 \\
a13118 & 7.7 & 6.1 & 2.5 & 1.0 & 5.7 \\
\hline
\end{tabular}

Brunton's genus from Australia and Scotland, respectively. Besides the presence of a dorsal myophragm, the Belgian material is distinguished from Serratocrista fistulosa in its more flattened dorsal valve. Our specimens are markedly smaller than the Serpukhovian species Serratocrista dalriensis and $S$. cylindricosta, both described by Mclntosh (1974). The Belgian species differs from S. truyolsi Martínez Chacón, 1979 from the Moscovian of Spain (see also Martínez Chacón, 2008) in its planoconvex shell and the not so deep dorsal median depression. The species from Tournai is relatively close to the Tournaisian (China) and Visean (Australia) Serratocrista sp. described by Sun and Baliński (2008) and Roberts (1971), respectively, but differs in its more divergent socket ridges.

Occurrence. Serratocrista scaldisensis is currently only known from the Tournai Formation in the Tournai area.

Order ATHYRIDIDA Boucot, Johnson and Staton, 1964

Suborder ATHYRIDIDINA Boucot, Johnson, and Staton, 1964

Superfamily ATHYRIDOIDEA Davidson, 1881

Family ATHYRIDIDAE Davidson, 1881

Subfamily ATHYRIDINAE Davidson, 1881

Genus LAMELLOSATHYRIS Jin and Fang, 1983

Type species. Spirifer lamellosus Léveillé, 1835, from the Tournaisian of the Tournai area, southern Belgium.

Lamellosathyris lamellosa (Léveillé, 1835)

Figures 4, 20-24, Table 3

1835 Spirifer lamellosus Léveillé, p. 39, pl. 2, figs. 21-23.

1836 Spirifer squamosa Phillips, p. 220, pl. 10, fig. 21.

1843 Terebratula lamellosa Léveillé; de Koninck, p. 299, pl. 20, fig. 5.

1868 Athyris (Spirifer) lamellosa (sic) Lév.; Dewalque, p. 333.

1881 Athyris (Spirifer) lamellosa (sic) Lév.; Mourlon, p. 46.

Athyris lamellosa Léveillé; de Koninck, p. 79, pl. 21, figs. 1-5.

V 1887

Athyris vittata de Koninck, p. 81, pl. 21, fig. 6-8.

1887 Athyris squamosa Phillips; de Koninck, p. 80 , pl. 21, figs. 9-10.

1980 Brunton, p. 225, figs. 16-17. 


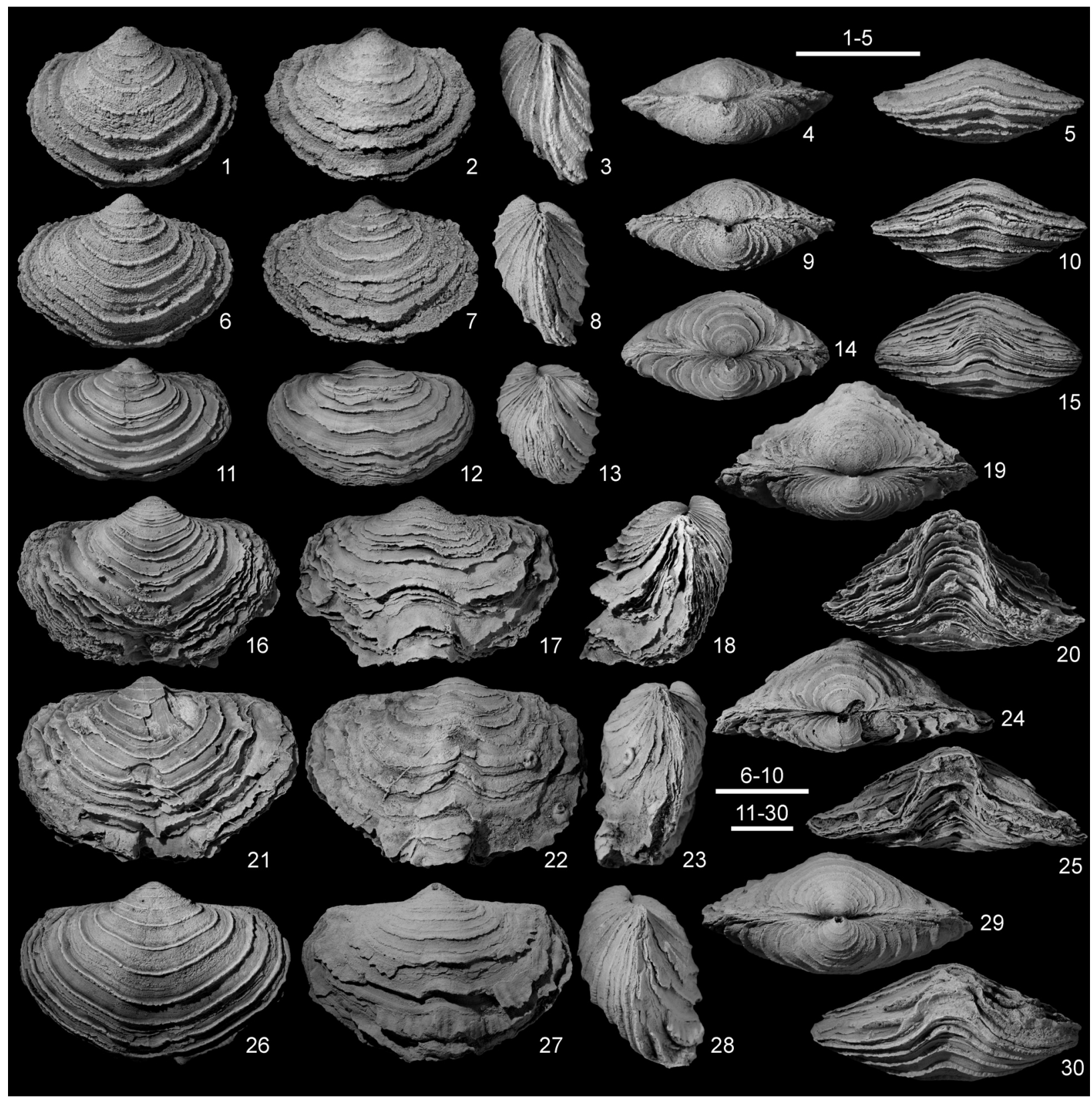

FIGURE 20. Lamellosathyris lamellosa (Léveillé, 1835) from the Tournai area, Tournai Formation (Tournaisian). 1-5, RBINS a13119, juvenile articulated specimen in ventral, dorsal, lateral, posterior and anterior views. 6-10, RBINS a13120, articulated specimen in ventral, dorsal, lateral, posterior, and anterior views. 11-15, RBINS a5468, articulated specimen in ventral, dorsal, lateral, posterior, and anterior views. 16-20, RBINS a13121, articulated specimen in ventral, dorsal, lateral, posterior, and anterior views. 21-25, RBINS a13122, articulated specimen (with two microconchids attached to the right dorsal flank) in ventral, dorsal, lateral, posterior and anterior views. 26-30, RBINS a13123, articulated specimen in ventral, dorsal, lateral, posterior, and anterior views. Scale bars equal $10 \mathrm{~mm}$.

Neotype. Specimen BMNH B20138 selected by Brunton (1980: p. 225, fig. 16).

Material. RBINS: besides the three specimens illustrated as Athyris lamellosa by de Koninck (1887, pl. 21, figs. 1-5), namely RBINS a5468 (pl. 21, figs. 1-3) (Figure 20.11-15), RBINS a5469 (pl.
21, fig 4), and RBINS a5470 (pl. 21, fig. 5) (Figure 21.19-23), complemented by those identified as Athyris vittata (de Koninck,1887, pl. 21, figs. 6-8; RBINS a5472) (Figure 23.8-12) and Athyris squamosa (de Koninck, 1887, pl. 21, figs. 9-10; RBINS a5471) (Figure 23.1-5), the RBINS material investi- 


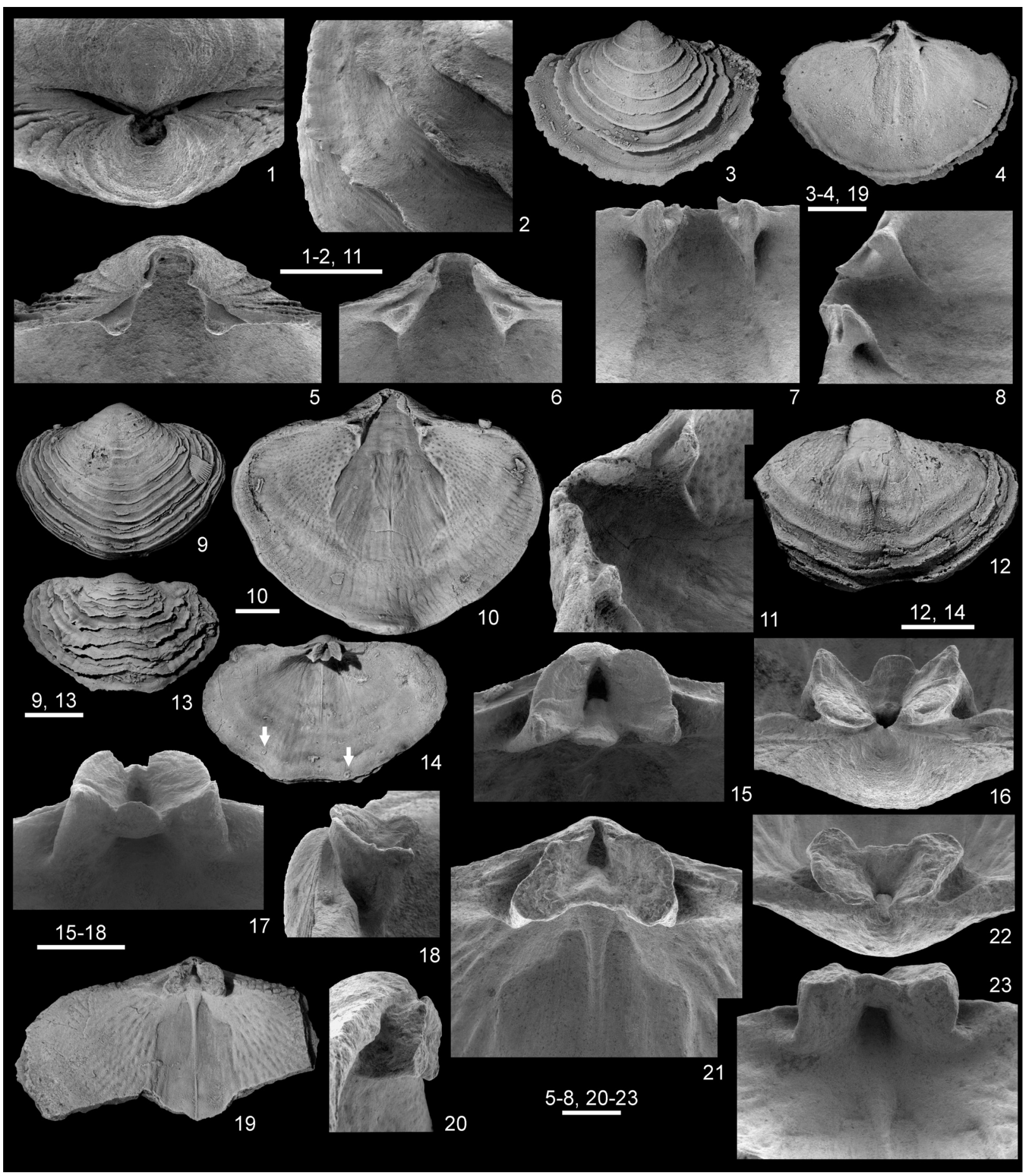

FIGURE 21. Lamellosathyris lamellosa (Léveillé, 1835) from the Tournai area, Tournai Formation (Tournaisian). 1-2, RBINS a13124, partial posterior view of an articulated specimen showing the foramen and detail of the lamellose ornamentation in the anterior part of the dorsal valve. 3-8, RBINS a13125, complete ventral valve (juvenile) in external and internal views and detail of the teeth and the dental plates. 9-11, RBINS a13126, complete ventral valve in external and internal views and detail of teeth supported by almost vertical dental plates. 12, RBINS a13127, incomplete internal mould of ventral valve. 13-18, ULg.PA.2016.12.25/8, complete dorsal valve (with two microconchids attached to its internal surface (arrows), close to the anterior margin) in external and internal view and detail of the cardinalia. 19-23, RBINS a5470, incomplete dorsal valve in internal view and detail of the cardinalia. Scale bars equal $5 \mathrm{~mm}(1-2,3-4,10,11), 2 \mathrm{~mm}(5-8,20-23), 2.5 \mathrm{~mm}(15-18), 10 \mathrm{~mm}(9,12-14)$. 


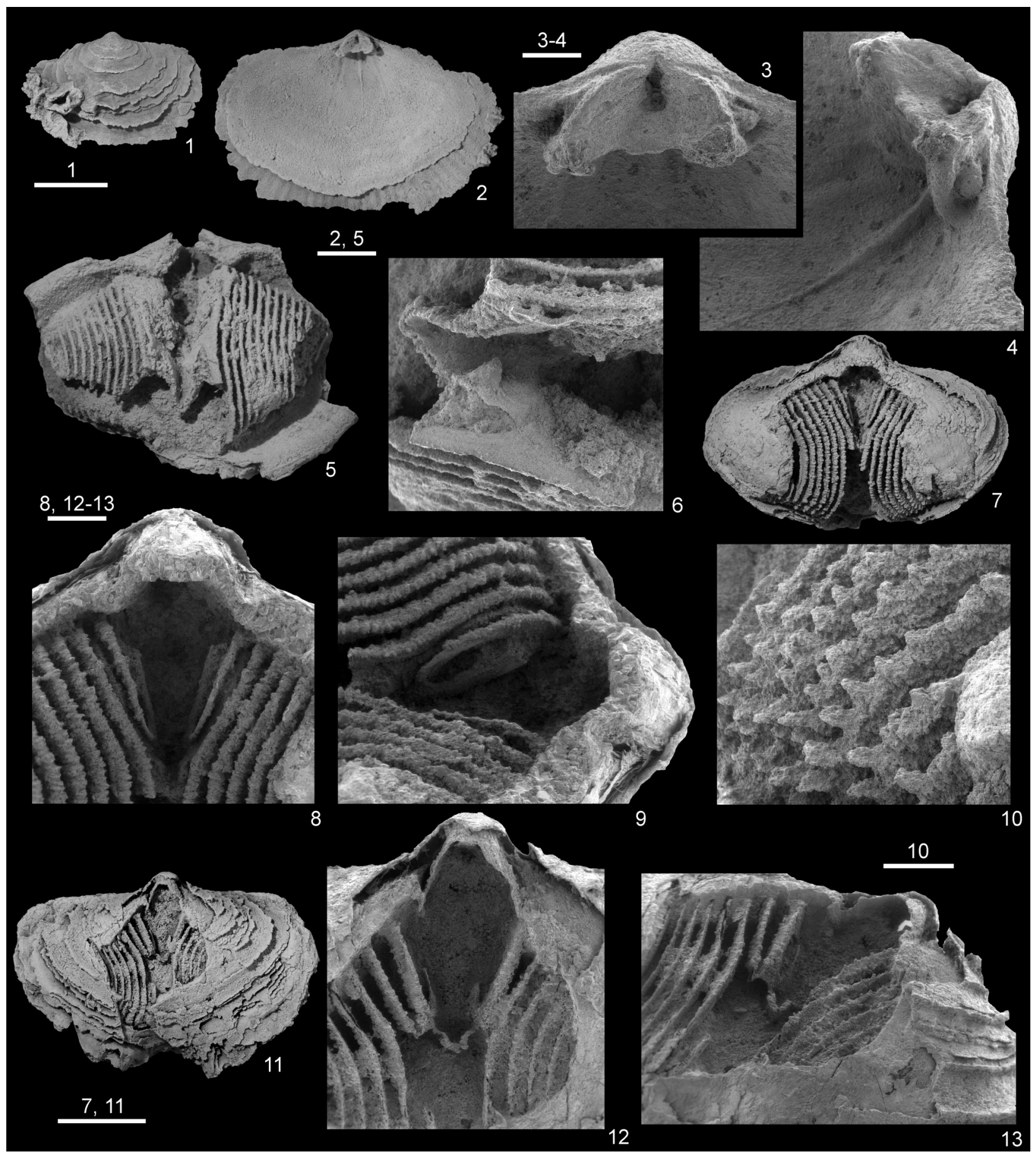

FIGURE 22. Lamellosathyris lamellosa (Léveillé, 1835) from the Tournai area, Tournai Formation (Tournaisian). 1-4, RBINS a13128, almost complete dorsal valve in external and internal views, with close-up of the cardinal plate in ventral and oblique lateral views. 5-6, RBINS a13129, incomplete ventral valve with partly preserved spiralia and detail of the jugal saddle and the primary lamella. 7-10, RBINS a13130, articulated specimen with top of the ventral valve removed and details of the crura, spiralia and fimbria. 11-13, ULg.PA.2016.12.25/9, articulated specimen with ventral valve partly removed in general view and details of the top of the jugal stem and the same in oblique view. Scale bars equal $10 \mathrm{~mm}(1,7,11), 5 \mathrm{~mm}(2,5), 1 \mathrm{~mm}(3-4,10), 2 \mathrm{~mm}(6,9), 2.5 \mathrm{~mm}(8,12-13)$. 


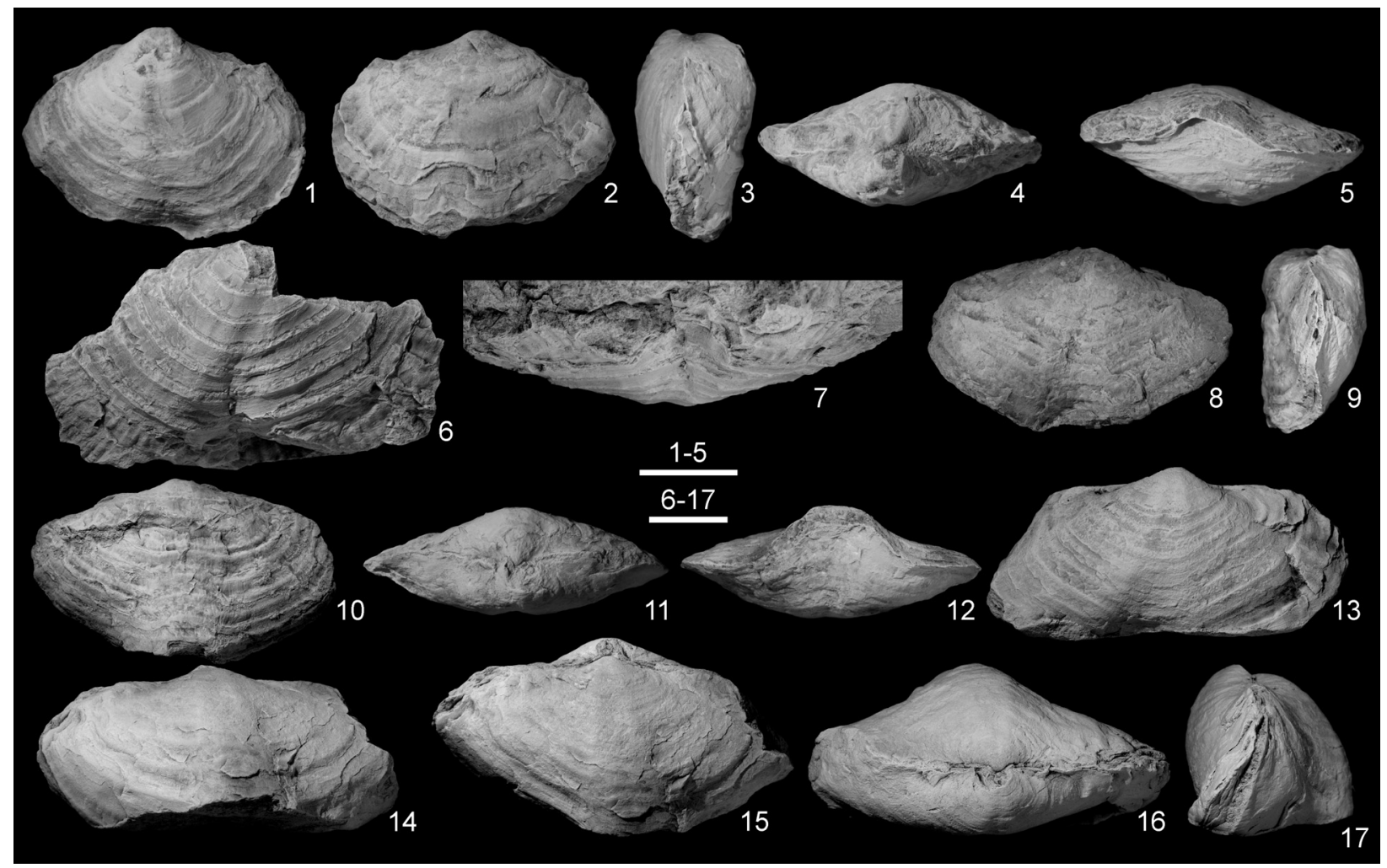

FIGURE 23. 1-7, Lamellosathyris lamellosa (Lévéillé, 1835) from Visé, Visé Formation (Visean, Warnantian). 1-5, RBINS a5471, distorted specimen in ventral, dorsal, lateral, posterior and anterior views. 6-7, RBINS a13131, incomplete ventral valve in ventral view and anterior views. 8-17, Athyris vittata de Koninck, 1887 (here placed in synonymy with Lamellosathyris lamellosa [Léveillé, 1835]) from Furfooz, Waulsort Formation (Tournaisian, Ivorian). 8-12, RBINS a5472 (lectotype) distorted specimen in ventral, lateral, dorsal, posterior, and anterior views. 13-17, RBINS a13132 (paralectotype), distorted and incomplete specimen in ventral, dorsal, posterodorsal, posterior, and lateral views. Scale bars equal $10 \mathrm{~mm}$.

gated includes 126 articulated specimens, six ventral and one dorsal valves; ULg.PA: 31 articulated specimens, one ventral and one dorsal valves.

Description. Shell large-sized (up to $51 \mathrm{~mm}$ in width), wider than long, transversely oval in outline, generally dorsibiconvex to rarely convexo-plane; hinge line shorter than maximum width; cardinal extremities rounded; anterior margin variably emarginate; anterior commissure uniplicate (rectimarginate to vaguely undulose in juveniles).

Ventral valve with prominent umbo; beak slightly overhanging hinge line, incurved; foramen small, permesothyrid (Figure 21.1); palintropes well-developed, concave; sulcus originating inconspicuously in the posterior part of the valve, illdefined, shallow to deep (only in largest specimens), round-bottomed at front; tongue high, round to subrectangular in outline, perpendicular to commissural plane or bent dorsally.

Dorsal valve inflated with maximum convexity at anterior margin or near midlength and then decreasing near anterior margin; fold low to high, originating near midlength, and only well perceptible near the anterior margin, exceptionally with a very shallow, median groove (Figure 21.13).

Shell covered by broad rugae, each about $3.5-4.5 \mathrm{~mm}$ wide at midlength (about 5-9 on 15 $\mathrm{mm}$ from the tip of the ventral umbo), but more crowded near the lateral and anterior commissures, and bearing thin to sometimes thickened growth lines (exact number unknown); radially corrugated shell flanges extending from rugae on both valves.

Ventral interior (Figure 21.4-8, 10-12) with thin, short dental plates converging dorsally then becoming subparallel anteriorly; teeth cyrtomatodont, stout, ovate; umbonal cavity large; lateral apical cavities poorly developed; muscle field clearly excavated posteriorly, large, subrounded in outline, with posteromedian elongate heart-shaped adductor scar enclosed laterally and anterolaterally by flabellate diductor scars extending up to $60 \%$ of 


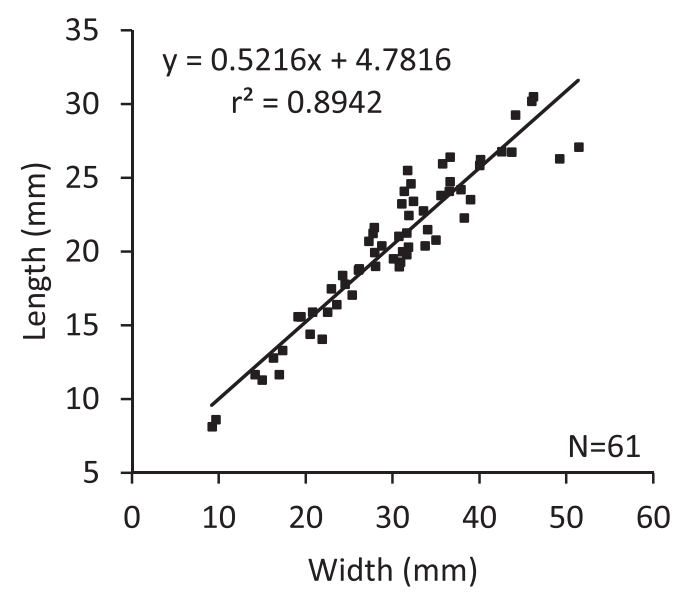

1

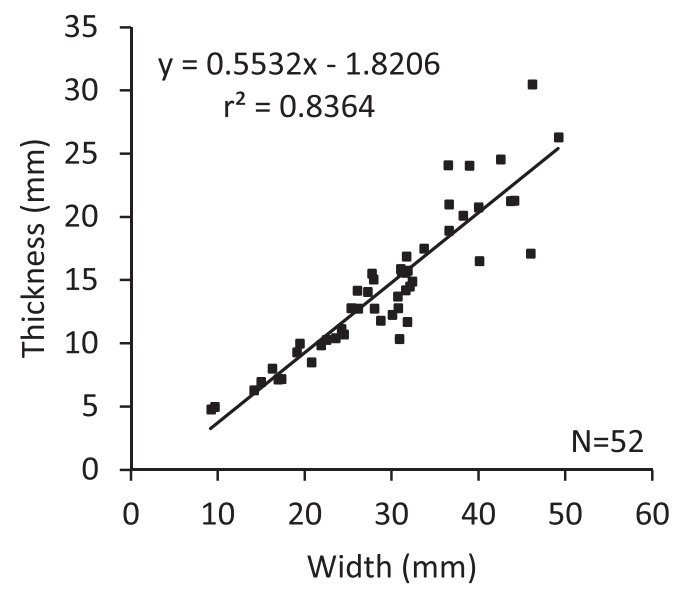

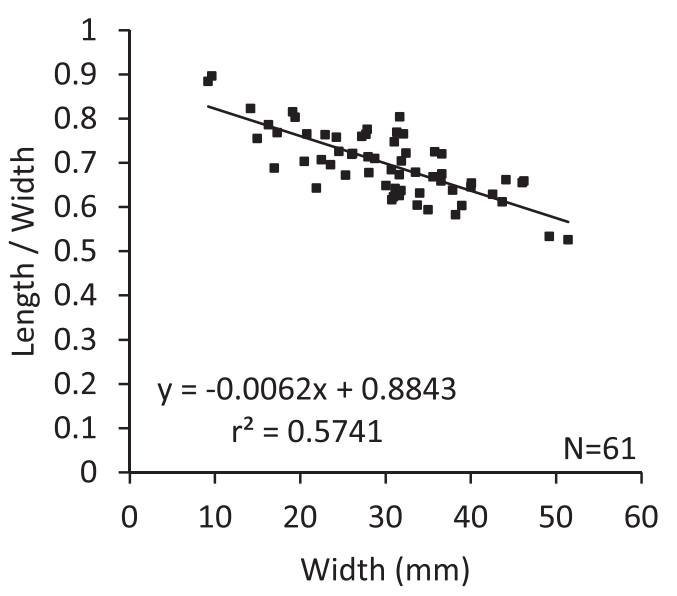

2

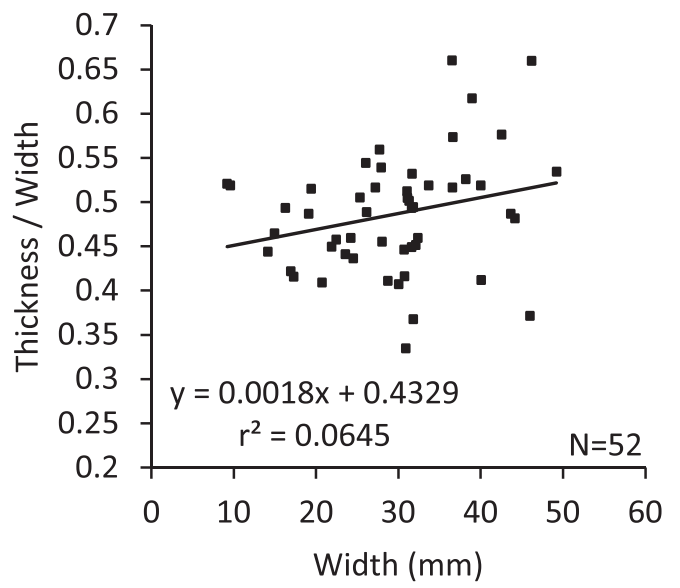

3

FIGURE 24. Scatter diagrams of Lamellosathyris lamellosa (Léveillé, 1835). N: number of specimens measured, $r^{2}$ : coefficient of linear regression. 1, Relation between shell width and length. 2, Relation between shell width and shell width/shell length ratio. 3, Relation beween shell width and thickness. 4, Relation between shell width and shell thickness/shell width ratio.

the unrolled length of the valve; posterolateral parts of the valve markedly pitted; mantle canals observed close to the anterior and lateral commissures.

Dorsal interior (Figures 21.14-23, 22.2-4) with cardinal plate extending anteriorly ca. $13 \%(n=2)$ of the valve length, subtrapezoidal in outline, pierced apically by a foramen; inner hinge plate wide, flat to convex; crural bases well-developed; dental sockets delimited by inner socket ridges clearly more developed than outer socket ridges; posterior bilobate cardinal flanges developed; adductor muscle scars variably excavated posterolaterally according to the specimens, but more obscure anteriorly, and medially divided by a low myophragm extending to $57 \%$ of the valve length in the largest available specimen; spiral cones with at least 16 whorls (this number is slightly underesti- mated due to their poor preservation), with fimbriae; jugum composed anteriorly by a jugal saddle and posteroventrally by a thin jugal stem bifurcating into short accessory jugal lamellae (Figure 22.5-13).

Dimensions (Figure 24, Table 3). The increasing of the shell length is proportional to the increasing of the shell width, and these parameters are quite stable through growth. The increasing of the thickness of the shell is a more variable parameter. The length/width ratio is significantly decreasing during growth indicating that the width increases quite more than the length in this species. On the contrary, the relation thickness/width to width is not significant. The very slight increasing of this ratio is due to the variability of the thickness variation through growth. 
TABLE 3. Measurements in mm of Lamellosathyris lamellosa (Léveillé, 1835). Abbreviations: see Table 1.

\begin{tabular}{lcccccc}
\hline & $\mathbf{W}$ & $\mathbf{L}$ & $\mathbf{T}$ & $\mathbf{L} / \mathbf{W}$ & $\mathbf{T} / \mathbf{W}$ & $\mathbf{T} / \mathbf{L}$ \\
\hline $\mathrm{N}$ & 60 & 60 & 50 & 60 & 50 & 50 \\
Mean & 30.1 & 20.5 & 14.5 & 0.70 & 0.49 & 0.70 \\
Standard deviation & 9.3122 & 5.1365 & 5.6788 & 0.0761 & 0.0667 & 0.1282 \\
Standard error & \pm 1.2021 & \pm 0.6631 & \pm 0.8031 & \pm 0.0098 & \pm 0.0094 & \pm 0.0181 \\
MIN & 9.2 & 8.1 & 4.8 & 0.53 & 0.33 & 0.53 \\
MAX & 51.4 & 30.5 & 30.5 & 0.90 & 0.66 & 1.02 \\
\hline
\end{tabular}

Remarks. Differences between Lamellosathyris lamellosa and other $L$. species (see Chen et al., 2003) have been discussed in detail by Carter (1967), Brunton (1980, 1984), Chen et al. (2003), and Sour-Tovar et al. (2005). However, contrary to Brunton's opinion reported in Chen et al. (2003), L. lamellosa reaches a size similar to that of $L$. qaidamensis Chen et al., 2003.

Athyris vittata de Koninck, 1887 from the Tournaisian Waulsort Formation is here considered as a synonym of Léveillé's (1835) species. Only some specimens assigned to this species have been recovered from the de Koninck collection curated at the RBINS. The single specimen illustrated by de Koninck (1887, pl. 21, figs. 6-8) is here selected as the lectotype (RBINS a5472) (Figure 23.8-12). Among the four additional specimens identified as A. vittata by de Koninck (1887) but not illustrated by him, only two are identical to the lectotype and thus have to be considered as paralectotypes RBINS a13132 (Figure 23.13-17) and RBINS a13133 (a juvenile not illustrated herein). According to Demanet (1958), the macrofaunas from the Waulsortian mounds from southern Belgium were studied by de Koninck (e.g., 1885, 1887) at the request of the Belgian geologist Edouard Dupont, who wanted to show that the Waulsortian calcareous facies corresponded to an autonomous stage of the Dinantian as the Tournaisian and the Visean (see Lees [2006] and Groessens [2006]), and thus characterized by a distinct fauna. That is why almost all the brachiopods and bivalves recovered from these massive carbonate bodies were assigned to new species by de Koninck.

The material from Visé (Visé Formation) identified as Athyris squamigera (Phillips, 1836) by de Koninck (1887) is illustrated here (Figure 23.1-5) as well as another specimen (Figure 23.6-7) from the same locality. Phillips' species has been considered for a long time as a synonym of $L$. lamellosa (see Brunton, 1984).

Occurrence. Among the athyridide species recognized from the Tournaisian succession of the Tour- nai area, Lamellosathyris lamellosa seems to have the most extensive distribution worldwide. It is notably known from the Mississippian succession of Western Europe (e.g., Brunton, 1980, 1984; Mottequin, 2010), North Africa (e.g., Massa et al., 1974; Havlíček and Röhlich, 1987; Mergl and Massa, 1992; Mottequin et al., 2017), Mexico (Sour-Tovar et al., 2005), the USA (Carter, 1999), and Iran (Gaetani, 1968; Bahrammanesh et al., 2011). In the Tournai area, Demanet (1958) reported $L$. lamellosa from the Orient Formation to the Vaulx Member of the Tournai Formation, i.e., from the latest Hastarian to the Ivorian. Demanet (1958) also reported its presence in various levels of the Tournaisian succession of southern Belgium, notably in the Yvoir and Waulsort formations, but the species is rare in the Visé Formation (Visean).

Superfamily NUCLEOSPIROIDEA Davidson, 1881

Family NUCLEOSPIRIDAE Davidson, 1881

Genus NUCLEOSPIRA Hall in Davidson, 1858

Type species. Spirifer ventricosus Hall, 1857; from the Lower Helderberg Group, Lochkovian, New York, USA.

Nucleospira hannoniae nom. nov. Figures 4, 25-27, Table 4

zoobank.org/D0C28E95-500A-414D-A599-41B9B7344AB3

$$
\begin{array}{lll}
\text { v } & 1887 & \begin{array}{l}
\text { Athyris globulina de Koninck, p. 78, pl. } \\
19, \text { figs. 42-46. }
\end{array} \\
\quad & 1893 & \begin{array}{l}
\text { Athyris globulina; Dewalque, p. 74. } \\
1989
\end{array} \\
\quad \begin{array}{l}
\text { Cleiothyridina globulina (Koninck, 1887); } \\
\text { Grunt, p. 84. }
\end{array}
\end{array}
$$

Etymology. From Hannonia (Latin: Hainaut), in reference to the Hainaut Province where the town of Tournai is located.

Type specimens. Same as those of Athyris globulina de Koninck, 1887 that are selected herein. The specimen RBINS a5465 (de Koninck, 1887, pl. 19, figs. 42-45) is selected here as the lectotype (Figure 25.11-15) whereas the specimen RBINS a5466 


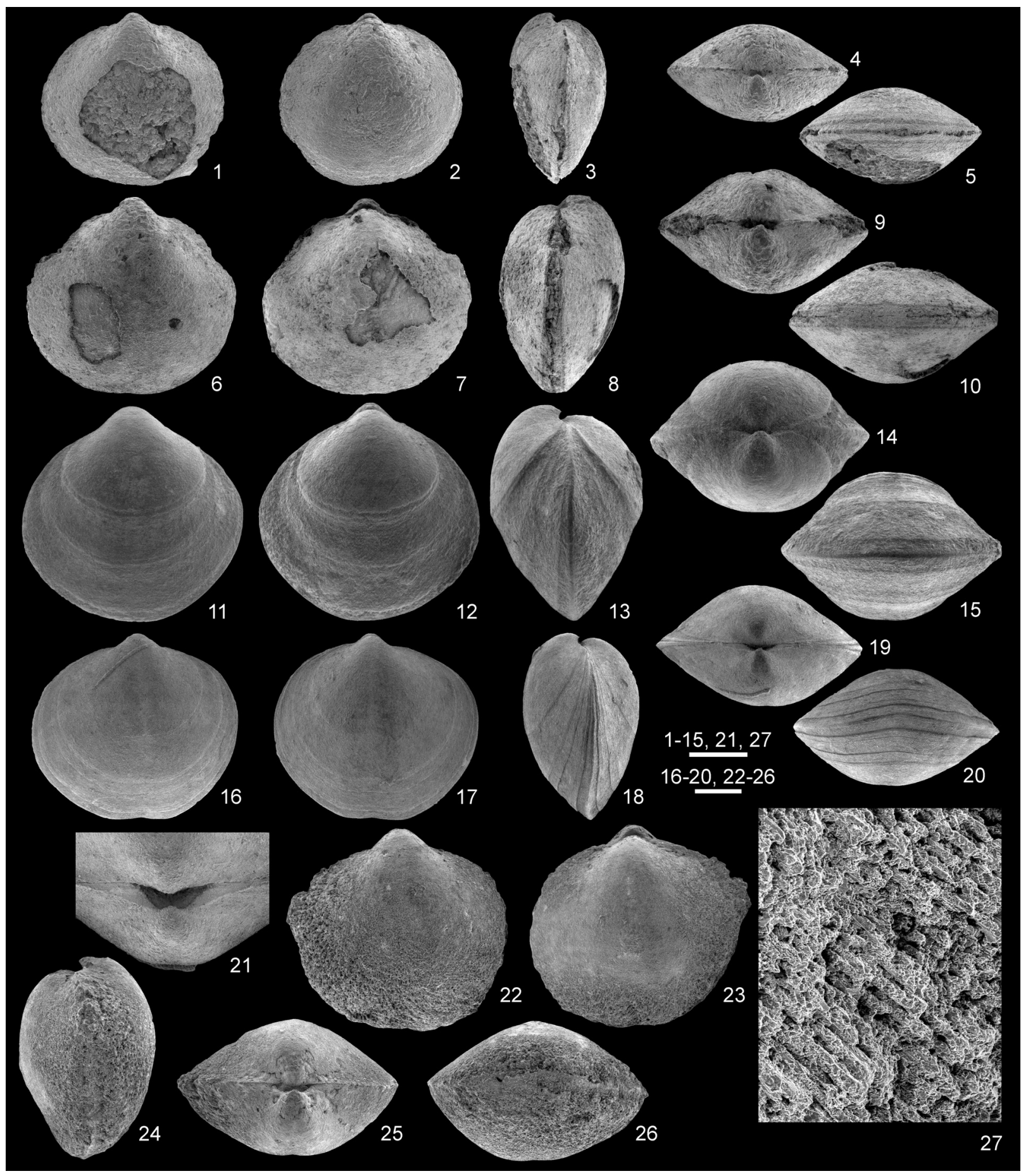

FIGURE 25. Nucleospira hannoniae nom. nov., from the Tournai area, Tournai Formation (Tournaisian). 1-5, RBINS a13134, articulated specimen, almost complete, in ventral, dorsal, lateral, posterior and anterior views. 6-10, RBINS a5466 (paralectotype), articulated specimen, almost complete, in ventral, dorsal, lateral, posterior ,and anterior views. 11-15, RBINS a5465 (lectotype), articulated specimen in ventral, dorsal, lateral, posterior, and anterior views. 16-21, RBINS a13135, articulated specimen in ventral, dorsal, lateral, posterior, and anterior views, and close-up of the interarea, Lemay quarry, Vaulx Member. 22-27, RBINS a13136, articulated specimen in ventral, dorsal, lateral, posterior, and anterior views, and close-up of the solid spines (right flank of the dorsal valve). Scale bars equal $2 \mathrm{~mm}$ $(1-20,22-26), 1 \mathrm{~mm}(21), 0.2 \mathrm{~mm}(21,27)$. 


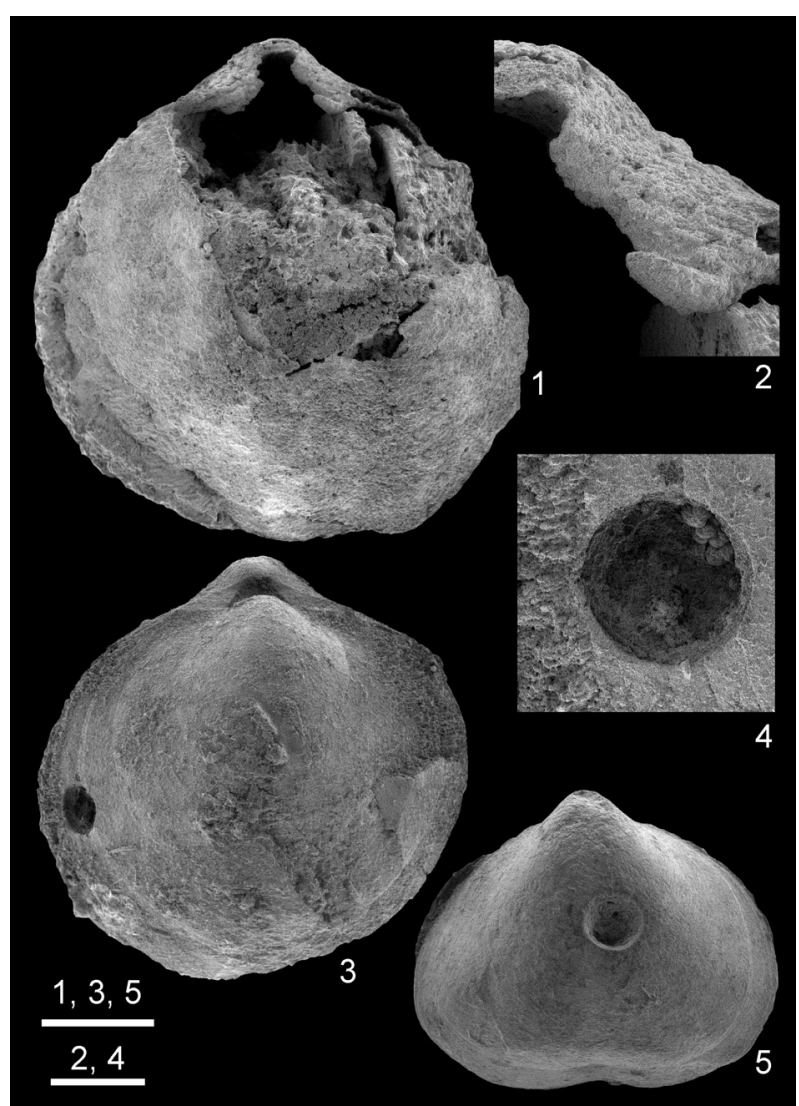

FIGURE 26. Nucleospira hannoniae nom. nov., from the Tournai area, Tournai Formation (Tournaisian). 1-2, RBINS a13137, distorted and incomplete specimen in dorsal view showing two whorls of the spiralium and detail of one of the cyrtomatodont teeth. 3-4, RBINS a13138, distorted articulated specimen in dorsal view displaying a circular drill hole and detail of the latter. 5, RBINS a13139, distorted articulated specimen with a circular drill hole in ventral view. Scale bars equal $2 \mathrm{~mm}(1$, 3, 5), $0.5 \mathrm{~mm}(2,4)$.

(de Koninck, 1887, pl. 19, fig. 46) is a paralectotype (Figure 25.6-10).

Additional material. RBINS: 13 articulated specimens; ULg.PA: 8 articulated specimens.

Description. Shell small-sized (up to $10 \mathrm{~mm}$ in width), biconvex, slightly wider than long, subcircular in outline; hinge line clearly shorter than maximum width; anterior margin rounded to very slightly emarginate; anterior commissure rectimarginate to slightly undulose.

Ventral valve with flanks moderately sloping towards lateral commissures; umbo small but prominent; beak curved, not in contact with dorsal umbo; interarea low, triangular, apsacline, concave; delthyrium large, open (no deltidial plates observed due to deficient preservation [?]); shallow median depression occasionally developed and originating inconspicuously near umbo; no tongue.

Dorsal valve highest posteriorly to midvalve then decreasing progressively towards anterior margin; flanks sloping gently to moderately towards lateral commissures; no fold.

Shell smooth with only some irregularly spaced and thickened growth lines; spines solid, densely crowded, long (rarely preserved) (Figure 25.27).

Ventral interior poorly known (Figure 26.1-2); teeth cyrtomatodont, small.

Dorsal interior unknown; only some whorls observed (Figure 26.1).

Dimensions (Figure 27, Table 4). An insufficient number of specimens have been measured. The scatter diagrams just indicate that relations between width and length of the shell or between the width and the thickness of the shell seem not affected by a large variability. The length/width or thickness/width ratios seem stable during the growth.

Remarks. The presence of solid spines covering the shell surface and the apsacline ventral interarea are characteristic of the genus Nucleospira, but their internal morphology was not investigated. Athyris globulina Waagen, 1883 (now included in Cleiothyridina Buckman, 1906; see Angiolini, 1995) and $A$. globulina de Koninck, 1887 are primary homonyms as rightly stressed by Grunt (1989), who included the latter species in Cleiothyridina. De Koninck's species is a junior primary homonym and must be renamed: Nucleospira hannoniae. The name-bearing type of Nucleospira hannoniae remains that of Athyris globulina de Koninck, 1887 (not Waagen, 1883) (see above).

There are few reports of the genus Nucleospira in the Mississippian of Western Europe (Brunton, 1984; Mottequin et al., 2015); this is most probably related to the small size of its representatives. Several species were described in the Mississippian of North America (see Weller, 1914, and Carter and Carter, 1970), while Pennsylvanian representatives of the genus are very rare according to Carter and Poletaev (1998). Externally, N. hannoniae is very close to $N$. carlukensis (Davidson, 1859) but according to Brunton (1984), the anterior commissure of the latter is commonly weakly uniplicate due to the presence of a sulcus whereas, in our very restricted material, it is generally rectimarginate (sulcus generally absent). Only the observation of the internal morphology of the material from Tournai will permit to better discriminate (or otherwise) both species. $N$. hannoniae differs from $N$. 


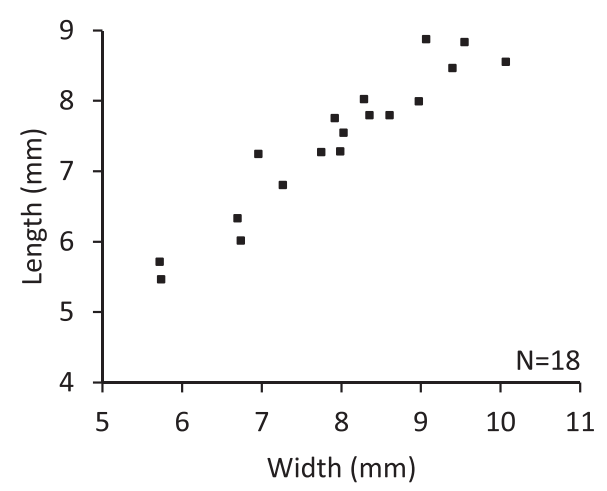

1

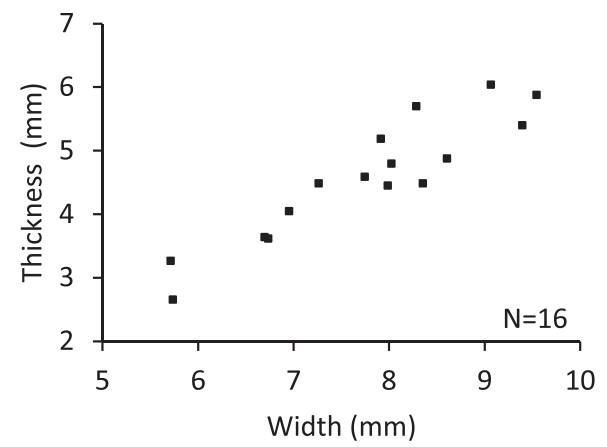

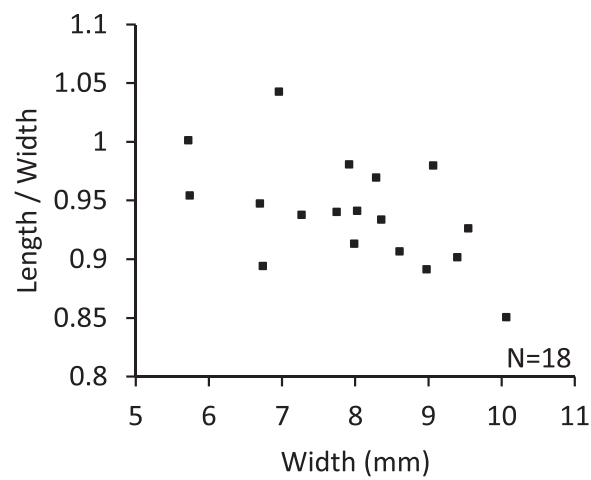

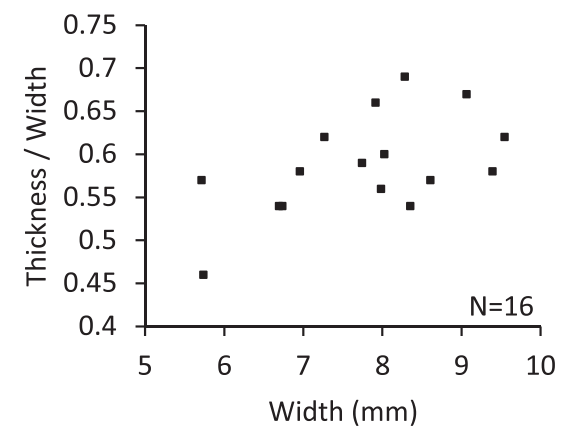

2

4

FIGURE 27. Scatter diagrams of Nucleospira hannoniae nom. nov. N: number of specimens measured. 1, Relation between shell width and length. 2, Relation between width and shell length/shell width ratio. 3, Relation beween shell width and thickness. 4, Relation between shell width and shell thickness/shell width ratio.

barrisi White, 1860 by the absence of a tongue (rectimarginate vs. uniplicate anterior commissure). On the basis of its external features, Nucle-

TABLE 4. Measurements in $\mathrm{mm}$ of Nucleospira hannoniae nom. nov. Abbreviations: see Table 1.

\begin{tabular}{lccccc}
\hline & $\mathbf{W}$ & $\mathbf{L}$ & $\mathbf{T}$ & $\mathbf{L} / \mathbf{W}$ & $\mathbf{T} / \mathbf{W}$ \\
\hline $\mathrm{N}$ & 18 & 19 & 16 & 18 & 16 \\
Mean & 7.9 & 7.5 & 4.6 & 0.94 & 0.59 \\
MIN & 5.7 & 5.5 & 2.7 & 0.85 & 0.46 \\
MAX & 10.1 & 9.5 & 6.0 & 1.04 & 0.69 \\
\hline
\end{tabular}

ospira hannoniae is close to $N$. obesa Rowley, 1900 but can be distinguished from the latter by its larger size and the usual absence of a ventral median depression.

Occurrence. Nucleospira hannoniae is presently known only from the Tournai Formation (at least in the Vaulx Member) of the Tournai area. Dewalque (1893) reported Athyris globulina de Koninck, 1887 (not Waagen, 1883) within the Ourthe Formation (Figure 4), but the conspecificity with the species from Tournai has to be confirmed.

\section{Suborder RETZIIDINA Boucot, Johnson, and Staton, 1964 \\ Superfamily RETZIOIDEA Waagen, 1883 \\ Family NEORETZIIDAE Dagys, 1972 \\ Subfamily HUSTEDIINAE Grunt, 1986}

Genus COVEENIA Alvarez and Brunton, 2000

Type species. Retzia ulothrix de Koninck, 1843; from the Tournaisian of Tournai, Belgium.

Coveenia ulothrix (de Koninck, 1843)

Figures 4, 28
1843

1843

1868

1881

V $\quad 1887$

$? \quad 1958$

$? \quad 1969$
Terebratula crispata de Koninck, p. 292, pl. 19, fig. 5a-c.

Terebratula ulothrix de Koninck, p. 635 (replacement name).

Retzia (Terebratula) ulothrix, de Kon.; Dewalque, p. 332.

Retzia (Terebratula) ulothrix, de Kon.; Mourlon, p. 46.

Retzia ulothrix de Koninck; de Koninck, p. 92, pl. 22, figs. 1-4.

Retzia ulotrix (sic) de Koninck; Demanet, p. 121.

Retzia ulotrix (sic) de Kon.; Mortelmans, p. 33. 


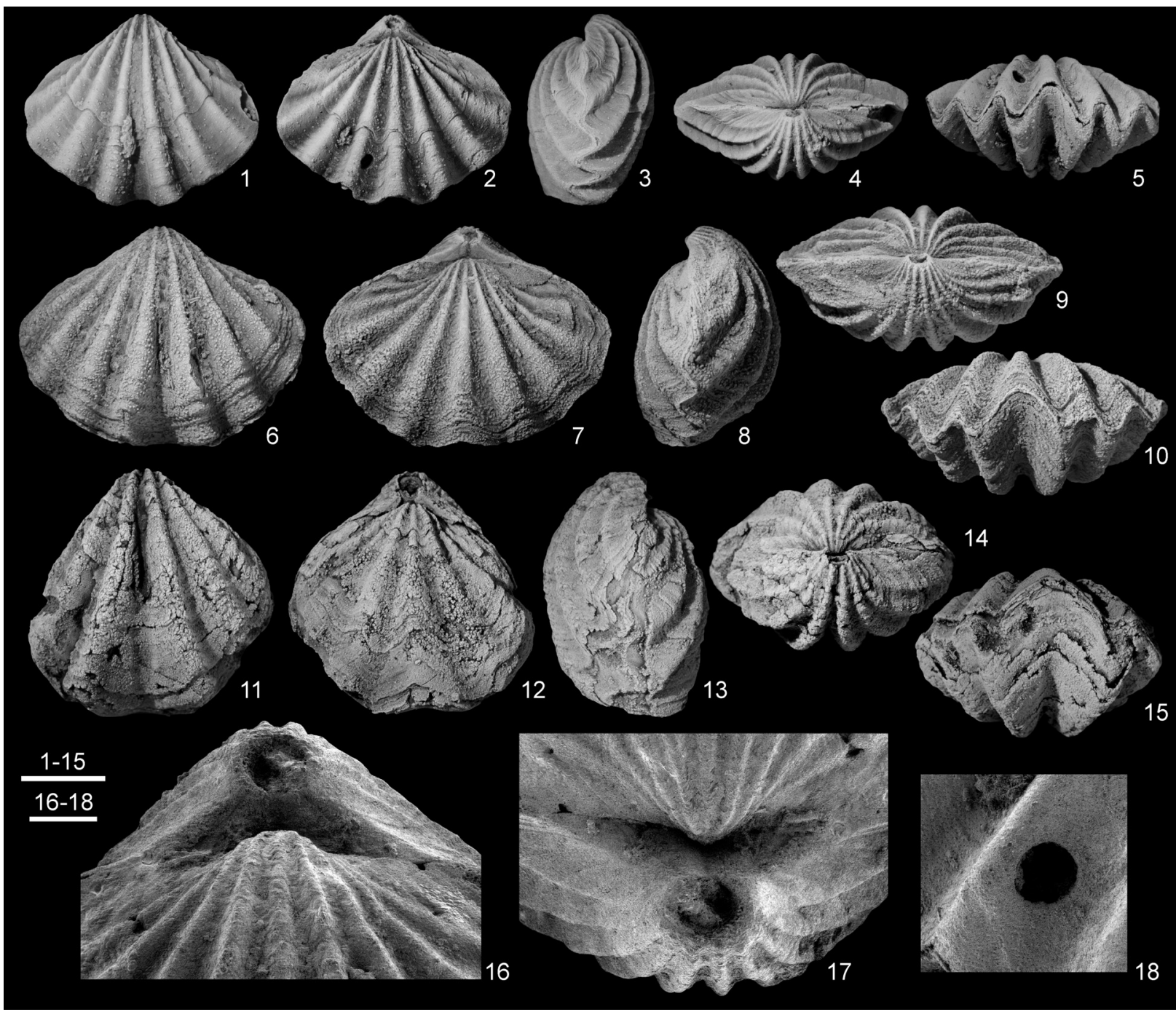

FIGURE 28. Coveenia ulothrix (de Koninck, 1843) from the Tournai area, Tournai Formation (Tournaisian). 1-5, 16-18, ULg.PA.2016.12.25/10, articulated specimen in ventral, dorsal, lateral, posterior and anterior views, and detail (SEM) of the foramen and the symphytium, and of circular drill hole developed close to the dorsal anterior margin. 6-10, RBINS a13140, articulated specimen in ventral, dorsal, lateral, posterior, and anterior views, Dutoit quarry, Pont-àRieu. 11-15, RBINS a13141, articulated specimen, almost complete, in ventral, dorsal, lateral, posterior and anterior views, Dutoit quarry, Pont-à-Rieu. Scale bar equals $10 \mathrm{~mm}$ (1-15), $1 \mathrm{~mm}$ (16-18).

v 2000

$\mathrm{v}$

2007
Coveenia ulothrix (de Koninck, 1843); Alvarez and Brunton, p. 822, pl. 1, figs. 110 , text-fig. 1-2, 5 (see for a more complete synonymy).

Coveenia ulothrix (de Koninck, 1843); Alvarez, p. 2769, figs. 1851-1852 (copy of Alavarez and Brunton, 2000, pl. 1, figs. 1-4, 6, text-fig. 2 (pro parte).

Material. Besides the material from the RBINS used by Alvarez and Brunton (2000), 18 additional articulated specimens; ULg.PA: four articulated specimens.
Remarks. Although this species has been redescribed thoroughly by Alvarez and Brunton (2000) on the basis of material from Tournai, three additional specimens are illustrated here (Figure 28.1-18) in order to provide the posterior views missing in Alvarez and Brunton's (2000) publication, and details of the permesothyrid foramen and the symphytium (Figure 28.16-17).

Occurrence. In Belgium, Coveenia ulothrix is known with certainty only from the Tournai area (Tournai Formation; Figure 4). Few specimens belonging to the genus Coveenia (C. sp. indet. in Figure 4) have been collected in the contempora- 
neous Yvoir Formation in the Dinant Synclinorium, but further material is required to reach a better identification. Two other Coveenia species are also recognized in Belgium (Figure 4): C. davidsoni (de Koninck, 1887) (see below) from the Waulsort Formation and C. buchiana (de Koninck, 1843) from the Visé Formation. The genus Coveenia is known from the Tournaisian-Visean of Western Europe, including British Isles (Alvarez and Brunton, 2000; Alvarez, 2007) but has also been doubtfully reported in the Tournaisian of Algeria by Mottequin and Legrand-Blain (2010).

Coveenia davidsoni (de Koninck, 1887) Figures 4, 29.1-4

\begin{tabular}{lll}
$\mathrm{v}^{*}$ & 1887 & $\begin{array}{l}\text { Retzia davidsoni de Koninck, p. 92, pl. } \\
\text { 22, fig. 10. }\end{array}$ \\
$?$ & \multirow{2}{*}{1923} & $\begin{array}{l}\text { Retzia davidsoni de Koninck; Demanet, } \\
\text { p. 189, pl. 11, fig. 87. }\end{array}$
\end{tabular}

Holotype. De Koninck (1887, p. 92) stressed on the fact that this species is based on a single poorly preserved specimen of the Dupont collection (RBINS a5508; Figure 29.1-4) from Dréhance (Waulsort Formation, Ivorian), which has to be considered as the holotype by monotypy.

Remarks. The limited material available for study cannot permit to fully describe this species, which is currently only represented by the holotype and assigned to Coveenia on the basis of its external features. This incomplete specimen is small (ca. 11 $\mathrm{mm}$ in width), wider than long, biconvex, and bears height high, rounded costae on the dorsal valve, which are separated by similar grooves. De Koninck (1887) presumably assumed that the holotype was identical to the two specimens from England identified as Retzia ulothrix by Davidson (1861, pl. 18, figs. 14-15). Alvarez and Brunton (2000) assigned the first specimen illustrated by Davidson (1861, pl. 18, fig. 14) to their new species Coveenia tilsleia whereas the second (Davidson, 1861, pl. 18, fig. 15) may belong to another species (see Alvarez and Brunton's (2000) synonymy list of C. tilsleia). However, de Koninck's (1887) species is less rostrate than $C$. tilsleia, but further material is required to provide a full description of this poorly known species and a detailed comparison with $C$. ulothrix. The specimen identified as Retzia davidsoni by Demanet (1923), originating from Sosoye (Waulsort Formation) has not been traced.

Occurrence. Coveenia davidsoni is only known from the Waulsortian mud mounds (Waulsort Formation, Tournaisian) in southern Belgium (Dinant sedimentation area).

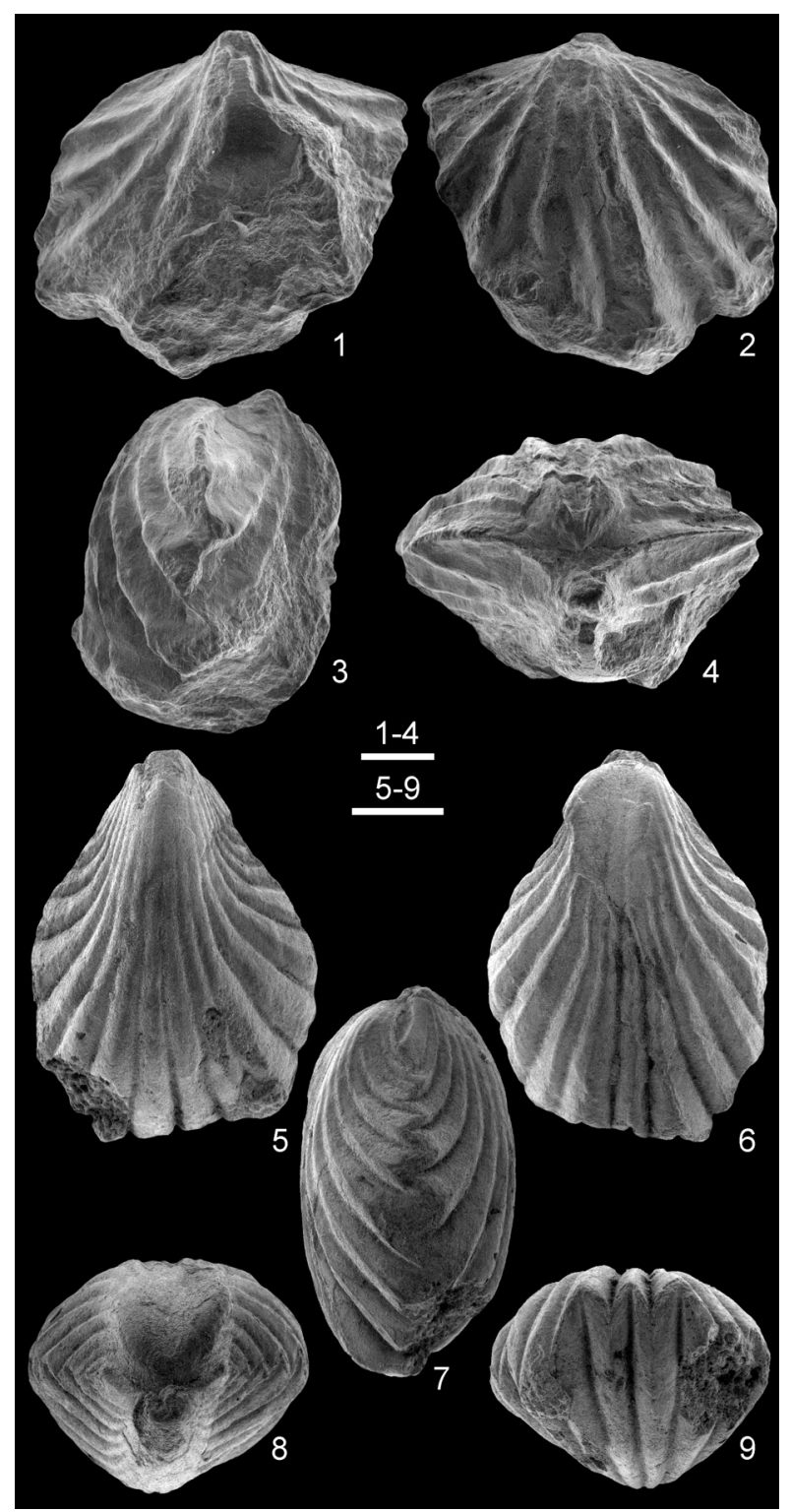

FIGURE 29. 1-4, Coveenia davidsoni (de Koninck, 1887), RBINS a5508 (holotype), articulated specimen in ventral, dorsal, lateral and posterior views, from Dréhance, Waulsort Formation (Tournaisian, Ivorian). 59, 'Retzia' intermedia de Koninck, 1887 (here considered as a rhynchonellide species), RBINS a5510 (lectotype), articulated specimen in ventral, dorsal, lateral, posterior and anterior views, from Furfooz, Waulsort Formation (Tournaisian, Ivorian). Scale bars equal $2 \mathrm{~mm}$.

\section{Systematic position of Retzia intermedia de Koninck, 1887}

Among the three new species briefly described by de Koninck (1887) and assigned to Retzia King, 1850 (R. davidsoni (= Coveenia davidsoni, see above), R. multiplicata (= Hustedia multiplicata, see Mottequin et al., 2015), and $R$. 
intermedia), the third is definitely not an athyridide, but a rhynchonellide on the basis of its external morphology. For purposes of nomenclatorial formality, the only specimen (RBINS a5510) illustrated by de Koninck (1887, pl. 22, figs. 11-15) from Furfooz (Figures 2-3) is selected herein as the lectotype of Retzia intermedia de Koninck, 1887 (Figure 29.5-9). The other specimens cited by de Koninck (1887) were not traced in the RBINS collections. The lectotype could be a juvenile, likely of one of the numerous costate rhynchonellide species occurring within the Waulsortian mudmounds from Belgium and illustrated by de Koninck (1887), Fraipont (1908), and Demanet (1923), but its precise identification requires their revision, which is well beyond the scope of this paper.

\section{DISCUSSION}

\section{Stratigraphic summary}

The stratigraphic range and the geographic distribution of the athyridides, orthotetides and strophomenides investigated in this study across the Namur-Dinant Basin are presented in Figure 4. Those of the representatives of the abovementioned orders were indicated by Demanet (1958) and Mortelmans (1969), but need to be revised.

\section{Some comments on the athyridide, orthotetide, and strophomenide diversity during the Devonian and the Mississippian in southern Belgium}

Strophomenides. One of the striking features of the Tournaisian-Visean brachiopod assemblage of the Namur-Dinant Basin is the re-occurrence of Leptaeninae (Rafinesquinidae) representatives both in mixed siliciclastic-carbonate ramp and buildup environments, after their absence during almost, if not, all of the Late Devonian in this area. The Family Rafinesquinidae, which first appeared during the Ordovician (Rong and Cocks, 1994), is the only strophomenide family to cross the Frasnian-Famennian (late Frasnian Crisis) and the Devonian-Carboniferous (Hangenberg Crisis at the end of the Famennian) boundaries, and become extinct by the Bashkirian according to Curry and Brunton (2007). No modern study of Devonian Leptaeninae representatives from Belgium is available.

In southern Belgium, the first Devonian Leptaeninae are known from the Pragian (Godefroid in Godefroid et al., 1994), although they occur in this area at the top of the Silurian (Pridolian) (e.g., Boucot, 1960; Godefroid and Cravatte, 1999). Their last Middle Devonian occurrence is recorded within the late Eifelian (Maillieux, 1938; Godefroid, 1968; Bultynck, 1970). Maillieux (e.g., 1940a, 1940b, 1941) and Mottequin (2008a) did not mention rafinesquinids in the Givetian-Frasnian succession of southern Belgium, a time span during which Strophomenida are represented by douvillinids and leptostrophiids in this area, and maybe strophodontids, but further investigations are needed. The presence of Leptaeninae in the early Famennian of the Namur-Dinant Basin is doubtful according to Maillieux (1941). They were reported within the uppermost Famennian (Strunian) by Demanet (1958), but this report has to be revised. In north-western France, namely in the Avesnois area (Figure 2) which corresponds to the western prolongation of the Namur-Dinant Basin, Leptaeninae were reported in the uppermost Famennian by Dehée (1929) and Brice et al. (2013), but this occurrence has been challenged by Mottequin and Brice (2016). Elsewhere in the world, several authors reported their occurrence in Frasnian and Famennian deposits (e.g., Karapetov, 1971; Xu (in Xu and Yao, 1988), Mergl and Massa, 1992; Brice in Brice et al., 2005; Alekseeva, 2011; Popov in Ghobadi Pour et al., 2013; Baranov et al., 2016; Zong et al., 2016). The absence of Leptaeninae from the Givetian-Famennian interval in southern Belgium is quite strange as, during the same time, the long-ranging orthide genus Schizophoria, which was already associated to the last Eifelian Leptaeninae, did not temporarily disappear and is even one of the first to recover after the FrasnianFamennian Crisis in Belgium (Mottequin, 2008b; Mottequin and Poty, 2016), and persisted after the Hangenberg Crisis. They flourished again during the Tournaisian-Visean, notably in Europe (e.g., Demanet, 1934; Pocock, 1968; Żakowa, 1989).

After the Hangenberg Crisis, Leptaeninae proliferated in some argillaceous and carbonate environments of Tournaisian age, a time interval marked by the transition between the Devonian greenhouse and the Carboniferous icehouse climates (e.g., Bruckschen et al., 1999; Buggisch et al., 2008), notably in Western Europe (e.g., Demanet, 1934; Bassett and Bryant, 2006; Mottequin, 2010), North America (e.g., Carter, 1968, 1987, 1988, 1999), Australia (Cvancara,1958; Thomas, 1971), Russia (Sokolskaya in Sarytcheva et al., 1963; Gretchischnikova, 1966), Iran (Bahrammanesh et al., 2011), and China (Shi et al., 2005; Sun and Baliński, 2008). The range of leptaenines (identified as Leptaena analoga) within the Hastarian and Ivorian of southern Belgium has 
been indicated by Demanet $(1934,1958)$. According to his data, they are clearly more abundant in the argillaceous and mixed carbonate-argillaceous environments than in more carbonate ones, such as the encrinitic facies that prevailed during the Ivorian. Until now, their only Visean occurrence is reported in the upper Visean buildup of Visé, where they seem to be confined (Demanet, 1934). At Visé, besides Leptagonia cf. caledonica, de Koninck (1843) and Demanet (1934) reported the presence of Leptaena distorta Sowerby, 1840, which is the type species of Pseudoleptaena Miloradovich, 1947 , a genus which is generally considered as a synonym of Leptagonia (e.g., Williams, 1965; Cocks and Rong, 2000), although the general shape of Sowerby's species is markedly different of the type species of Leptagonia. The revision of this material from Visé has still to be carried out, but it is included in Figure 4 as L.? distorta. The recurrence of siliciclastic environments at the onset of the Serpukhovian in relation with the glaciations did not favour their return in southern Belgium as they are absent at the end-Mississippian (Demanet, 1941). In contrast, Brand (1972, 2011) recorded leptaenines in the Arnsbergian (Serpukhovian) of Scotland and Northern Ireland whereas Carter et al. (2014) stressed on the fact the genus Leptagonia first appeared within the basal Tournaisian and temporarily disappeared at the end of this stage before reappearing in North America during the late Serpukhovian.

Orthotetides. Representatives of this order were common within the Devonian-Mississippian succession of southern Belgium but were generally not abundant, except in some Visean horizons (Demanet, 1934). There, Devonian species remain relatively poorly documented (e.g., de Koninck, 1882; Maillieux, 1909, 1939; Boucot, 1960; Long and Brunton, 2005; Mottequin, 2008a), whereas their Carboniferous counterparts have never been revised since Demanet's (1934, 1938, 1941, 1943) monographs, except the partial revision herein. It is currently not possible to discuss precisely the consequences of the Hangenberg Crisis on the representatives of this order as the most recent data (lists of species) date back to Demanet (1958). Further work is thus needed to better assess the diversity of the Tournaisian and Viséan orthotetides, although a large a part of them was previously described by Demanet (1934). As is the case for many of the brachiopod orders (e.g., productides, spiriferides), their specific diversity unsurprisingly reaches a zenith within the Visean (Warnantian) buildups composed of massive algal and bioclastic boundstones similar to the English Cracoean facies (Mundy, 1994) and some of these Warnantian species reach a very large size (more than $100 \mathrm{~mm}$ in width) in comparison with their Tournaisian counterparts. Note that numerous orthotetide species were described within the Mississippian succession of Western Europe, especially in Great Britain and Ireland, notably by Phillips (1836), M'Coy (1844), Thomas (1910), Smyth (1930), and Reed (1954), but despite some partial revisions of these pioneering works by Brunton (1968), McIntosh (1974), and Bassett and Bryant (2006), many of them are still poorly known.

Athyridides. In spite of their great abundance in diverse environments, our knowledge of the Devonian athyridides from Belgium is still strongly lacunar despite some recent contributions on their Middle and Late Devonian representatives (Godefroid and Mottequin, 2005; Mottequin, 2004, 2008a, 2008b; Mottequin et al., 2016). Known since the Lochkovian (Asselberghs, 1930; Boucot, 1960; Godefroid and Cravatte, 1999), most of the Lower and Middle Devonian athyridides are only known by lists of species or brief descriptions generally devoid of illustrations (e.g., Asselberghs, 1923; Maillieux, 1931, 1932, 1941) and thus insufficient to provide a detailed analysis of their change in diversity through Devonian time in this part Laurussia.

During the Tournaisian and Visean, these spire-bearers seem to rank among the most diverse brachiopod orders from the specific viewpoint along with the productides and spiriferides in the Namur-Dinant Basin, as for the Devonian counterparts, only their thorough revision will permit to assess their real diversity. Athyridida were described by Léveillé (1835) and de Koninck $(1843,1851,1887)$, especially from Tournai and Visé, but most of them have never been revised and are still only known by embellished drawings, except those discussed and re-illustrated by Brunton (1980, 1984), Alvarez and Brunton (2000), Mottequin et al. (2015), Mottequin and Simon $(2015,2017)$, and the present paper.

Among the Tournaisian Athyridoidea, the Subfamily Cleiothyridininae includes the genera Carteridina and Cleiothyridina represented by several species previously described by Léveillé (1835) and de Koninck $(1843,1851,1887)$, whose revision is in progress. In northern France and southern Belgium, cleiothyridinines (Cleiothyridina) are firstly recorded in the Frasnian (Mottequin, 2008b; Brice et al., 2008), but this subfamily encountered there a great development during the Famennian 
with other undescribed Cleiothyridina species and more particularly with several Crinisarina ones (Mottequin, 2008a, 2008b). Thus, cleiothyridinines took part to post-Kellwasser brachiopod recovery, a phenomenon well-known elsewhere in the world (e.g., Baliński, 2002), but also after the Hangenberg Crisis. In contrast, Tournaisian athyridines (Lamellosathyris) and spirigerellines (Composita) are less diverse specifically. However, it is important to stress on the fact that in some Viséan reef facies of the Namur-Basin, Composita representatives (or at least identified as such) are so locally abundant that they provided substantial firm ground for reef builder encrustation (e.g., Chevalier and Aretz, 2005). Moreover, representatives of the superfamilies Retzioidea (Coveenia, Hustedia) and Nucleospiroidea (Nucleospira) were generally minor components of the brachiopod assemblages from the Tournaisian and Visean successions of the Namur-Dinant Basin, even if Hustedia and Nucleospira seem to be more abundant in Warnantian carbonate buildup environment, such at the top of the Visé Formation, but this needs to be confirmed.

\section{Palaeobiology}

Life position. The largest specimens of Leptagonia franca are characterized by the great development of shelly expansions both laterally and postero-anteriorly, which induces the formation of a kind of flattened ledge by the lateral parts of the trail as observed by Hoel $(2005,2014)$ in Silurian Leptaeninae. In relation with the development of such shelly structures, the supra-apical foramen disappears through ontogeny reflecting the loss of utility of the functional pedicle. These observations reflect an early anchored lifestyle followed by an ambitopic one (e.g., Jaanusson, 1979; Bassett, 1984; Rachebœuf, 1991; Hoel, 2014), lying on its ventral valve and floating in a soft substrate thanks to its long trail, very wide and flattened alae. However, the position of the epizoans (craniide brachiopods and microconchids) may also indicate that the shell lived in vertical position (e.g., Spjeldnaes, 1984; Hoel, 2014) with the umbo pointing downwards, during a significant part of the ontogeny as reflected by the presence of the supra-apical foramen. Note that the life orientation of concavo-convex brachiopods is still hotly disputed (e.g., Lescinsky, 1995; Leighton, 1998, 2005; Baliński, 2010; Mergl and Nolčová, 2016). The specimen RBINS a5895 (Figure 6.7-12) displays two epibionts on its ventral valve, namely a microconchid on the trail (but very close to the geniculation) and a craniide specimen sitting astride the disc and the trail (Figure 6.7-9). If this $L$. franca shell was resting on its ventral valve during its life, the growth of both epibionts was impossible as they were buried in the sediment. One can argue that the shell would have been exposed in a convex-up, hydrodynamically stable position after its death during a time interval sufficient to allow its colonization by epibionts. Nonetheless, this is unlikely, according to Hoel (2014), as the deltidiodont dentition of Leptaeninae is not strong enough to maintain the valves in close connection during a long time. In this case, and thus probably for most of the specimens (except the largest), the vertical position of life is the most probable. Another shell of similar size (RBINS a5829, Figure 6.1-6) displays craniide brachiopods attached to both the dorsal disc (Figure 6.3) and to the ventral trail (Figure 6.1, 6.4, 6.6). The state of preservation of $L$. caledonica did not permit to observe the presence of a supra-apical foramen.

The Tournaisian orthotetides Schellwienella radialiformis and Serratocrista scaldisensis display a small cementation cicatrix at the top of the ventral umbo with koskinoid perforations (Jux and Strauch, 1966) (Figures 13.12, 18.19-21), of which the origin is still controversial: drilling by organisms (Thomas, 1958; Williams and Brunton, 1993) or resulting from the development of an attachment organ (e.g., Schumann, 1969, Grant, 1976, 1980; Martínez Chacón and García-Alcalde, 1978). The reduced size of the cementation cicatrix may indicate that the fixation to a hard substrate was only effective during the early growth stages of these brachiopods (Bassett, 1984). In contrast, in the lectotype of Schellwienella ornata, a large part of the ventral umbonal area is flattened (Figure 15.1).

The morphology and mode of life of athyridide brachiopods was discussed in great detail by Alvarez (1990).

Predation. One articulated shell of Schellwienella radialiformis (Figure 13.6-10) displays damage probably resulting from the bite of a predator (fish?) in the centre of the posterior half of the ventral valve and at close to the right posterior margin (the interarea is also affected). It took place during a relatively early stage of the growth of the brachiopod and was not lethal as reflected by the deviation of the radial ornamentation and the distortion of the shell outline. Similar phenomena, which were observed recently in spiriferides from the Tournai Formation by Mottequin and Simon (2017), were discussed notably by Baliński (1993) and Sun and Baliński (2011). Circular drill holes perpendicular to 
shell surface similar to those described by Mottequin and Sevastopulo (2009) on Crurithyris goldfussiana and Mottequin and Simon (2017) on other spiriferide species were observed rarely in Serratocrista scaldisensis (Figure 17.12), Nucleospira hannoniae (Figure 26.3-5), and Coveenia ulothrix (Figure 28.2, 28.18).

Epizoans. Brachiopods from the Tournai Formation are commonly encrusted by different kinds of epizoans according to the nicely preserved material curated at the RBINS and the ULg (Mottequin and Simon, 2017). The most common epizoans are the tentaculitoid tubeworms (microconchids) (Figures 6.7-12, 12.21-25, 20.21-25, 21.14), auloporides (Figure 5.13-18), and craniide brachiopods (Figure 6.1-12). Some of these epibionts clearly colonized brachiopods that were already dead before encrustation; this is particularly evident with an isolated dorsal valve of Lamellosathyris lamellosa (ULg.PA.2016.12.25/8) bearing two microconchids on its internal surface (Figure 21.14). The case of the craniides attached to Leptagonia franca are discussed above.

\section{ACKNOWLEDGEMENTS}

The SEM images of the brachiopods were taken at the Royal Belgian Institute of Natural Sciences at Brussels by J. Cillis. We thank $\mathrm{N}$. Monaghan and M.A. Parkes who provided access to the collections of the National Museum of Ireland (Dublin). V. Fischer is thanked for the loan of the material curated at the University of Liège. The manuscript benefited from the thorough reviews of F. Alvarez and an anonymous reviewer, and from the editiorial help of C. Haug.

\section{REFERENCES}

Alekseeva, R.E. 2011. Devonian strophomenides (Brachiopoda) from Mongolia. Paleontological Journal, 45:270-272.

Alvarez, F. 1990. Devonian athyrid brachiopods from the Cantabrian Zone (NW Spain). Biostratigraphie $d u$ Paléozoïque, 11:1-311.

Alvarez, F. 2007. Athyridida, p. 2742-2771. In Selden, P.A. (ed.), Treatise on Invertebrate Paleontology, Part $H$ (Revised), 6 (Supplement). Geological Society of America and University of Kansas, Boulder, Colorado, and Lawrence, Kansas, 1-3226.

Alvarez, F. and Brunton, C.H.C. 2000. A review of two de Koninck retzioid brachiopod species, and description of a new genus from the Carboniferous of Europe. Palaeontology, 43:817-832.

Alvarez, F. and Rong, J.-Y. 2002. Athyridida, p. 14751601. In Kaesler, R.L. (ed.), Treatise on Invertebrate
Paleontology, Part H (Revised), 4. Geological Society of America and University of Kansas, Boulder, Colorado, and Lawrence, Kansas, 1-3226.

Angiolini, L. 1995. Permian brachiopods from Karakorum (Pakistan). Pt. 1 (With Appendix). Revista Italiana di Paleontologia e Stratigrafia, 101:165-214.

Aretz, M. and Chevalier, E. 2007. After the collapse of stromatoporid-coral reefs - the Famennian and Dinantian reefs of Belgium: much more than Waulsortian mounds. Geological Society, London, Special Publications, 275:163-188.

Asselberghs, E. 1923. La faune de la Grauwacke de Rouillon (base du Dévonien moyen). Mémoires du Musée royal d'Histoire naturelle de Belgique, 33:176.

Asselberghs, E. 1930. Description des faunes marines du Gedinnien de l'Ardenne. Mémoires du Musée royal d'Histoire naturelle de Belgique, 41:1-73.

Bahrammanesh, M., Angiolini, L., Antonelli, A.A., Aghababalou, B., and Gaetani, M. 2011. Tournaisian (Mississippian) brachiopods from the Mobarak Formation, North Iran. GeoArabia, 16:129-192.

Baliński, A. 1993. A recovery from sublethal damage to the shell of a Devonian spiriferoid brachiopod. Acta Palaeontologica Polonica, 38:111-118.

Baliński, A. 2002. Frasnian-Famennian brachiopod extinction and recovery in southern Poland. Acta Palaeontologica Polonica, 47:289-305.

Baliński, A. 2010. First colour-patterned strophomenide brachiopod from the earliest Devonian of Podolia, Ukraine. Acta Palaeontologica Polonica, 55:695-700.

Baranov, V.V., Sokiran, E.V., and Blodgett, R.B. 2016. Late Devonian (Famennian) brachiopods, conodonts, biogeography and sedimentary geology of Bel'kovsky Island (Russian Arctic). New Mexico Museum of Natural History and Science Bulletin, 74:25-40.

Bassett, M.G. 1984. Life strategies of Silurian brachiopods. Special Papers in Palaeontology, 32:237-263.

Bassett, M.G. and Bryant, C. 2006. A Tournaisian brachiopod fauna from south-east Wales. Palaeontology, 49:485-535.

Belanger, I., Delaby, S., Delcambre, B., Ghysel, P., Hennebert, M., Laloux, M., Marion, J.-M., Mottequin, B., and Pingot, J.-L. 2012. Redéfinition des unités structurales du front varisque utilisées dans le cadre de la nouvelle Carte géologique de Wallonie (Belgique). Geologica Belgica, 15:169-175.

Boucot, A.J. 1960. Lower Gedinnian brachiopods of Belgium. Mémoires de l'Institut géologique de l'Université de Louvain, 21:11-20.

Boucot, A.J., Johnson, J.G., and Staton, R.D. 1964. On some atrypoid, retzioid, and athyridoid Brachiopoda. Journal of Paleontology, 38:805-822.

Brand, P.J. 1972. Some British Carboniferous species of the brachiopod genus Leptagonia McCoy. Bulletin of the Geological Survey of Great Britain, 39:57-79.

Brand, P.J. 2011. The Serpukhovian and Bashkirian (Carboniferous, Namurian and basal Westphalian) 
faunas of northern England. Proceedings of the Yorkshire Geological Society, 58:143-165.

Brice, D., Legrand-Blain, M., and Nicollin, J.-P. 2005. New data on late Devonian and early Carboniferous brachiopods from NW Sahara Morocco, Algeria. Annales de la Société géologique du Nord (2ème série), 12:1-45.

Brice, D., Mottequin, B., and Loones, C. 2008. Découverte de nouveaux brachiopodes dans le Givetien (Dévonien) du Boulonnais (N. France). Annales de la Société géologique du Nord (2ème série), 15:1-14.

Brice, D., Nicollin, J.-P., and Mottequin, B. 2013. Diversity of strophomenid, orthotetid and orthid brachiopods in the uppermost Famennian ('Strunian'; Upper Devonian) of the Avesnois (northern France). Annales de la Société géologique du Nord (2ème série), 20:53-63.

Bruckschen, P., Oesmann, S., and Veizer, J. 1999. Isotope stratigraphy of the European Carboniferous: proxy signals for ocean chemistry, climate and tectonics. Chemical Geology, 161:127-163.

Brunton, C.H.C. 1968. Silicified brachiopods from the Viséan of County Fermanagh (II). Bulletin of the British Museum (Natural History), Geology, 16:3-70.

Brunton, C.H.C. 1980. Type specimens of some Upper Palaeozoic Athyridide brachiopods. British Museum (Natural History), Bulletin (Geology), 34:219-234.

Brunton, C.H.C. 1984. Silicified brachiopods from the Viséan of County Fermanagh, Ireland (III). Rhynchonellids, spiriferids and terebratulids. Bulletin of the British Museum (Natural History), Geology, 38:27-130.

Brunton, C.H.C. and Mundy, D.J.C. 1988. Strophalosiacean and Aulostegacean productoids (Brachiopoda) from the Craven Reef Belt (late Viséan) of North Yorkshire. Proceedings of the Yorkshire Geological Society, 47:55-88.

Brunton, C.H.C. and Mundy, D.J.C. 1994. A new productoid brachiopod from the late Visean Craven Reef Belt of North Yorkshire. Proceedings of the Yorkshire Geological Society, 50: 119-173.

Brunton, C.H.C. and Tilsley, J.W. 1991. A check list of brachiopods from Treak Cliff, Derbyshire, with reference to other Dinantian Lower Carboniferous localities. Proceedings of the Yorkshire Geological Society, 48:287-295.

Buckman, S.S. 1906. Brachiopod nomenclature: Epithyris, Hypothyris, Cleiothyris Phillips, 1841. Annals and Magazine of Natural History (Series 7), 18:321-327.

Buggisch, W., Joachimski, M.M., Sevastopulo, G., and Morrow, J.R. 2008. Mississippian $\delta^{13} C_{\text {carb }}$ and conodont apatite $\delta^{18} \mathrm{O}$ records-Their relation to the Late Palaeozoic Glaciation. Palaeogeography, Palaeoclimatology, Palaeoecology, 268:273-292.

Bultynck, P. 1970. Révision stratigraphique et paléontologique (brachiopodes et conodontes) de la coupe type du Dévonien. Mémoires de l'Institut géologique de l'Université de Louvain, 26:1-152.
Carter, J.L. 1967. Mississippian brachiopods from the Chappel Limestone of central Texas. Bulletins of American Paleontology, 53(238):248-488.

Carter, J.L. 1968. New genera and species of early Mississippian brachiopods from the Burlington Limestone. Journal of Paleontology, 42:1140-1152.

Carter, J.L. 1987. Lower Carboniferous brachiopods from the Banff Formation of western Alberta. Bulletin of Geological Survey of Canada, 378:1-183.

Carter, J.L. 1988. Early Mississippian brachiopods from the Glen Park Formation of Illinois and Missouri. Bulletin of the Carnegie Museum of Natural History, 27:1-82.

Carter, J.L. 1999. Tournaisian (early Osagean) brachiopods from a bioherm in the St. Joe Formation near Kenwood, Oklahoma. Annals of Carnegie Museum, 68:91-149.

Carter, J.L. and Carter, R.C. 1970. Bibliography and index of North American Carboniferous brachiopods (1898-1968). The Geological Society of America, Memoir, 128:1-382.

Carter, J.L. and Poletaev, V.I. 1998. Atokan (late Bashkirian or early Moscovian) brachiopods from the Hare Fiord Formation of Ellesmere Island, Canadian Arctic Archipelago. Annals of Carnegie Museum, 67:105180.

Carter, J.L., Brezinski, D.K., Kollar, A.D., and Dutro, J.T. Jr. 2014. Brachiopoda taxonomy and biostratigraphy of the Redwall Limestone (Lower Mississippian) of Arizona. Annals of Carnegie Museum, 82:257-290.

Chen, Z.Q., Shi, G.R., and Zhan L.P. 2003. Early Carboniferous athyridid brachiopods from the Qaidam Basin, northwest China. Journal of Paleontology, 77:844-862.

Chevalier, E. and Aretz, M. 2005. A microbe-bryozoan reef from the middle Visean of the Namur Syncline (Engihoul quarry). Geologica Belgica, 8:109-119.

Cocks, L.R.M. and Rong, J.-Y. 2000. Strophomenida, p. 216-349. In Kaesler, R.L. (ed.), Treatise on Invertebrate Paleontology, Part H (Revised), 2. Geological Society of America and University of Kansas, Boulder, Colorado, and Lawrence, Kansas, 1-3226.

Cooper, G.A. and Grant, R.E. 1974. Permian brachiopods of west Texas, II. Smithsonian Contributions to Paleobiology, 15:233-793.

Curry, G.B. and Brunton, C.H.C. 2007. Stratigraphic distribution of brachiopods, p. 2901-3081. In Kaesler, R.L. (ed.), Treatise on Invertebrate Paleontology, Part H (Revised), Brachiopoda, 6. Geological Society of America and University of Kansas, Boulder, Colorado, and Lawrence, Kansas, 1-3226.

Cvancara, A.M. 1958. Invertebrate fossils from the Lower Carboniferous of New South Wales. Journal of Paleontology, 32:846-888.

Dagys, A.S. 1972. Morfologiia i Systematika Mezozoiskikh Retsiodnykh Brakhiopod. Morfologicheskie i Filogeneticheskie Voprosy Paleontologii. Akademiia Nauk SSSR, Sibirskoe Otdelenie, Institut Geologii i Geofiziki, Trudy, 112:94-105. (In Russian) 
Davidson, T. 1858-1863. A monograph of the British fossil Brachiopoda. Volume 2, Part 4, Nos. 1-5. The Carboniferous Brachiopoda. Monograph of the Palaeontographical Society, London.

Davidson, T. 1880. Supplement to the Carboniferous Brachiopoda. A monograph of the British fossil Brachiopoda, Volume 4. Monograph of the Palaeontographical Society, London.

Davidson, T. 1881. On genera and species of spiralbearing Brachiopoda from specimens developed by the Rev. Norman Glass. Geological Magazine, New Series, Decade 2, 8:1-13.

de Béthune, P. 1954. Carte géologique de Belgique (échelle 1/500.000). Atlas de Belgique, planche 8. Académie royale de Belgique, Bruxelles.

Dehée, R. 1929. Description de la faune d'Etrœungt Faune de passage du Dévonien au Carbonifère. Mémoires de la Société géologique de France (nouvelle série), 5:1-62.

de Koninck, L.-G. 1842-1844. Description des animaux fossiles qui se trouvent dans le terrain carbonifère de Belgique. $\mathrm{H}$. Dessain, Liège.

de Koninck, L.G. 1847. Monographie du genre Productus. Mémoires de la Société Royale des Sciences de Liège, 4:73-278.

de Koninck, L.-G. 1851. Description des animaux fossiles qui se trouvent dans le terrain carbonifère de Belgique. Supplément. H. Dessain, Liège.

de Koninck, L.-G. 1882. Description de trois nouvelles espèces famenniennes. Bulletin de l'Académie royale des Sciences, des Lettres et des Beaux-Arts de Belgique (3ème série), 4:521-525.

de Koninck, L.-G. 1885. Faune du calcaire carbonifère de la Belgique. Cinquième partie. Lamellibranches. Annales du Musée royal d'Histoire naturelle de Belgique, 11:1-283.

de Koninck, L.-G. 1887. Faune du calcaire carbonifère de la Belgique. Sixième partie. Brachiopodes. Annales du Musée royal d'Histoire naturelle de Belgique, 14:1-154.

Demanet, F. 1923. Le Waulsortien de Sosoye et ses rapports fauniques avec le Waulsortien d'âge Tournaisien supérieur. Mémoires de l'Institut géologique de l'Université de Louvain, 2:37-285.

Demanet, F. 1934. Les brachiopodes du Dinantien de la Belgique. Premier volume. Atremata, Neotremata, Protremata (pars). Mémoires du Musée royal d'Histoire naturelle de Belgique, 61:1-116.

Demanet, F. 1938. La faune des couches de passage du Dinantien au Namurien dans le Synclinorium de Dinant. Mémoires du Musée royal d'Histoire naturelle de Belgique, 84:1-201.

Demanet, F. 1941. Faune et stratigraphie de l'étage Namurien de la Belgique. Mémoires du Musée royal d'Histoire naturelle de Belgique, 97:1-327.

Demanet, F. 1943. Les horizons marins du Westphalien de la Belgique et leurs faunes. Mémoires du Musée royal d'Histoire naturelle de Belgique, 101:1-166.
Demanet, F. 1958. Contribution à l'étude du Dinantien de la Belgique. Mémoires de l'Institut royal des Sciences naturelles de Belgique, 141:1-152.

de Ryckholt, P. 1851. Mélanges paléontologiques, première partie. Mémoires couronnés des Savants étrangers de l'Académie royale des Sciences, des Lettres et des Beaux-Arts de Belgique, 24:1-176.

Devuyst, F.-X. and Dehantschutter, J.A.E. 2007. Waulsortian carbonate mudbanks, Belgium. Mémoires du Muséum national d'Histoire naturelle, 195:235-238.

Dewalque, G. 1868. Prodrome d'une description géologique de la Belgique. Libraire polytechnique De Decq, Bruxelles and Liège.

Dewalque, G. 1893. Sur le calcaire carbonifère de la carrière de Paire (Clavier). Annales de la Société géologique de Belgique (Bulletins), 20:73-77.

Duméril, A.M.C. 1805. Zoologie analytique ou méthode naturelle de classification des animaux. Allais, Paris.

Easton, W.H., Sanders, J.E., Knight, J.B., and Miller, A.K. 1958. Mississippian fauna in the northwestern Sonora, Mexico. Smithsonian Miscellaneous collections, 119:41-72.

Fraipont, C. 1908. Notes sur quelques fossiles du Calcaire carbonifère. Annales de la Société géologique de Belgique (Mémoires), 35:7-12.

Gaetani, M. 1968. The geology of the upper Djadjerud and Lar valleys (North Iran). II. Palaeontology. Lower Carboniferous brachiopods from Central Elburz, Iran. Rivista Italiana di Paleontologia e Stratigrafia, 74:665-744.

Gaillard, C., Hennebert, M., and Olivero, D. 1999. Lower Carboniferous Zoophycos from the Tournai area (Belgium): environmental and ethologic significance. Geobios, 32:513-524.

Ghobadi Pour, M., Popov, L. E., Hosseini, M., Adhamian, A., and Yazdi, M. 2013. Late Devonian (Frasnian) trilobites and brachiopods from the Soh area, Central Iran. Memoirs of the Association of Australasian Palaeontologists, 44:149-158.

Godefroid, J. 1968. Contribution à l'étude du Couvinien entre Wellin et Jemelle (bord sud du bassin de Dinant). Mémoires de l'Académie royale de Belgique, Classe de Sciences, Collection in $-4^{\circ}$ (2ème série), 17:1-79.

Godefroid, J., Blieck, A., Bultynck, P., Dejonghe, L., Gerrienne, P., Hance, L., Meilliez, F., Stainier, P., and Steemans, P. 1994. Les formations du Dévonien inférieur du Massif de la Vesdre, de la Fenêtre de Theux et du Synclinorium de Dinant (Belgique, France). Mémoires pour servir à l'Explication des Cartes Géologiques et Minières de la Belgique, 38:1144.

Godefroid, J. and Cravatte, T. 1999. Les brachiopodes et la limite Silurien/Dévonien à Muno (sud de la Belgique). Bulletin de l'Institut royal des Sciences naturelles de Belgique, Sciences de la Terre, 69:526.

Godefroid, J. and Mottequin, B. 2005. Givetian brachiopods from the Trois-Fontaines Formation at Marenne 
(Belgium, Dinant Synclinorium). Bulletin de l'Institut royal des Sciences naturelles de Belgique, Sciences de la Terre, 75:5-23.

Godefroid, J., Mottequin, B. and Yochelson, E.L. 2006. Restudy of the Lower Carboniferous Scaphopoda described by de Koninck (1843, 1883). Bulletin de I'Institut royal des Sciences naturelles de Belgique, Sciences de la Terre, 76:137-163.

Grant, R.E. 1976. Permian brachiopods from Southern Thailand. Palaeontological Society Memoir, 9:1-269.

Grant, R.E. 1980. Koskinoid perforations in brachiopod shells: function and mode of formation. Lethaia, 13:313-319.

Gretchischnikova, I.A. 1966. Stratigrafiia i brakhiopody nizhnego karbona Rudnogo Altaia. Trudy Moskovskogo Obshchestva Ispytatelei Prirody, Seriia Geologii, 20: 1-184. (In Russian)

Groessens, E. 2006. Dinantian. Geologica Belgica, 9:157-162.

Grunt, T.A. 1986. Sistema brakhiopod otriada atiridida. Akademiia Nauk SSSR, Trudy Paleontologicheskogo Instituta, 215:1-200. (In Russian)

Grunt, T.A. 1989. Otriad Atiridida (evoliutsionnaia morfologiia i istoricheskoe razvitie). Akademiia Nauk SSSR, Trudy Paleontologicheskogo Instituta, 238:1141. (In Russian)

Hall, J. 1857. Descriptions of new species of Paleozoic fossils from the Lower Helderberg, Oriskany Sandstone, Upper Helderberg, Hamilton and Chemung Groups. New York State Cabinet of Natural History, Annual Report, 10:41-186.

Hall, J. and Clarke, J.M. 1894. An introduction to the study of the genera of Palaeozoic Brachiopoda, Natural History of New York, Palaeontology, Volume 8, Part 2. New York Geological Survey, Charles van Benthuysen and Sons. Albany.

Hance, L., Dejonghe, L., Ghysel, P., Laloux, M., and Mansy, J.-L. 1999. Influence of heterogeneous lithostructural layering on orogenic deformation in the Variscan Front Zone (eastern Belgium). Tectonophysics, 309:161-177.

Hance, L., Poty, E., and Devuyst, F.-X. 2001. Stratigraphie séquentielle du Dinantien type (Belgique) et corrélation avec le Nord de la France (Boulonnais, Avesnois). Bulletin de la Société géologique de France, 172:411-426.

Hance, L., Poty, E., and Devuyst, F.-X. 2006a. Tournaisian. Geologica Belgica, 9:47-53.

Hance, L., Poty, E., and Devuyst, F.-X. 2006b. Viséan. Geologica Belgica, 9:55-62.

Harper, D.A.T. and Jeffrey, A.L. 1996. The ontogeny of the silicified brachiopod Leptagonia from Mid-Dinantian (late Arundian) from western Ireland. Irish Journal of Earth Sciences, 15:77-90.

Havlíček, V. and Röhlich, P. 1987. Devonian and Carboniferous brachiopods from the northern flank of the Murzuq Basin (Libya). Sborník Geologických vĕd Paleontologie, 28:117-177.
Hennebert, M. 1996. Précession climatique et excentricité dans le «Calcaire de Tournai» (Tournaisien supérieur, Carbonifère inférieur), Belgique. Compte rendu de l'Académie des Sciences de Paris (série Ila), 322:445-452.

Hennebert, M. and Doremus, P. 1997a. Carte géologique de Wallonie à 1/25 000. Antoing-Leuze 37/7-8 (+ notice explicative). Ministère de la Région Wallonne, Namur.

Hennebert, M. and Doremus, P. 1997b. Carte géologique de Wallonie à 1/25 000. Hertain-Tournai 37/5-6 (+ notice explicative). Ministère de la Région Wallonne, Namur.

Hoel, O.E. 2005. Silurian Leptaeninae (Brachiopoda) from Gotland, Sweden. Paläontologische Zeitschrift, 79:263-284.

Hoel, O.E. 2014. Palaeobiology of Silurian Leptaeninae (Brachiopoda) from Gotland, Sweden. Paleontology Journal, 2014/716053:1-14.

International Commission on Zoological Nomenclature. 1999. International Code of Zoological Nomenclature, $4^{\text {th }}$ edition. International Trust for Zoological Nomenclature, London.

Ivanov, A.P. 1925. K sistematike i biologii roda Spirifer i o nekotorykh brakhiopodakh C2 i C3 Moskovskoi rubernii. Moskovskoe Obshchestvo Ispytatelei Prirody, Otdel Geologicheskii, 33(1-2):105-123. (In Russian)

Jaanusson, V. 1979. Ecology and faunal dynamics, p. 253-294. In Jaanusson, V., Laufeld, S., and Skoglund, R. (eds.), Lower Wenlock Faunal and Floral Dynamics-Vattenfallet Section, Gotland. Sveriges Geologiska Undersokning C, 762.

Jin, Y.G. and Fang, R.S. 1983. Early Carboniferous brachiopods from Shidian, Yunnan. Acta Palaeontologica Sinica, 22(2):139-151. (In Chinese)

Jux, U. and Strauch, F. 1966. Die Mitteldevonische brachiopoden-gattung Uncites Defrance 1825. Palaeontographica, Abteilung A, 125:176-222.

Karapetov, S.S. 1971. Stratigrafiya i Brakhiopody Verkhnego Devona Vostochnogo Pamira. Paleontologiya i Stratigraphiya. Upravlenie Geologii Soveta Ministrov Tadzhikskoi SSR, Trudy, 4:53-81. (In Russian)

King, W. 1846. Remarks on certain genera belonging to the class Palliobranchiata. Annals and Magazine of Natural History, 18:26-42, 83-94.

King, W. 1850. A Monograph of the Permian Fossils of England. Palaeontographical Society Monograph, $3: 1-258$

Lescinsky, H.L. 1995. The life orientation of concavoconvex brachiopods; overturning the paradigm. Paleobiology, 21:520-551.

Lees, A. 1982. The paleoenvironmental setting and distribution of the Waulsortian facies of Belgium and southern Britain, p. 1-16. In Bolton, K., Lane, H.R., and Lemone, D.V. (eds.), Symposium on the Environmental Setting and Distribution of the Waulsortian Facies. El Paso Geological Society and University of Texas, El Paso. 
Lees, A. 1997. Biostratigraphy, sedimentology and palaeobathymetry of Waulsortian buildups and periWaulsortian rocks during the late Tournaisian regression, Dinant area, Belgium. Geological Journal, 32:136.

Lees, A. 2006. Waulsortian. Geologica Belgica, 9:151155.

Leighton, L.R. 1998. Constraining functional hypotheses: controls on the morphology of the concavo-convex brachiopod Rafinesquina. Lethaia, 31:293-307.

Leighton, L.R. 2005. Comment - a new angle on strophomenid palaeoecology: trace-fossil evidence on an escape response for the plectambonitoid brachiopod Sowerbyella rugose from a tempestite in the Upper Ordovician Kope Formation (Edenian) of Northern Kentucky (Datillo, 2004). Palaios, 20:596-600.

Léveillé, C. 1835. Aperçu géologique de quelques localités très riches en coquilles sur les frontières de France et de Belgique. Mémoires de la Société géologique de France, 2:29-40.

Long, S.L. and Brunton, C.H.C. 2005. The problematic cemented Devonian brachiopod Schuchertellopsis durbutensis Maillieux, 1939. Geobios, 38:107-112.

M'Coy, F. 1844. A synopsis of the characters of the Carboniferous Limestone fossils of Ireland. Williams and Norgate, London.

Maillieux, E. 1909. Etude comparative de la répartition des espèces fossiles dans le Frasnien du bord méridional du bassin dinantais et dans les niveaux synchroniques du Boulonnais. Annexe. Notes sur les Streptorhynchus de la zone à Sp. Orbelianus du Frasnien de l'Ardenne. Bulletin de la Société belge de Géologie, de Paléontologie et d'Hydrologie (Mémoires), 23:115-151.

Maillieux, E. 1931. La faune des Grès et Schistes de Solières (Siegenien Moyen). Mémoires du Musée royal d'Histoire naturelle de Belgique, 51:1-90.

Maillieux, E. 1932. La faune de l'Assise de Winenne (Emsien Moyen) sur les bordures méridionale et orientale du bassin de Dinant. Mémoires du Musée royal d'Histoire naturelle de Belgique, 52:1-102.

Maillieux, E. 1933. Terrains, roches et fossiles de la Belgique, deuxième édition. Patrimoine du Musée royal d'Histoire naturelle de Belgique, Bruxelles.

Maillieux, E. 1938. Le Couvinien de l'Ardenne et ses faunes. Mémoires du Musée royal d'Histoire naturelle de Belgique, 83:1-57.

Maillieux, E. 1939. La faune des schistes de Barvauxsur-Ourthe (Frasnien supérieur). Bulletin du Musée royal d'Histoire naturelle de Belgique, 15(53):1-8.

Maillieux, E. 1940a. Contribution à la connaissance du Frasnien moyen (Assise de Frasnes) de la Belgique. Bulletin du Musée royal d'Histoire naturelle de Belgique, 16(14):1-44.

Maillieux, E. 1940b. Documents pour servir à l'étude du Givetien de l'Ardenne. Bulletin du Musée royal d'Histoire naturelle de Belgique, 16(7):1-13.
Maillieux, E. 1941. Répartition des brachiopodes dans le Dévonien de l'Ardenne. Bulletin du Musée royal d'Histoire naturelle de Belgique, 27(30):1-14.

Martin, W. 1793. Figures and descriptions of petrifications collected in Derbyshire. Lyon and Atkinson, Wigan.

Martin, W. 1809. Petrificata Derbiensia; or figures and descriptions of petrefactions collected in Derbyshire. Lyon, Wigan.

Martínez Chacón, M.L. 1979. Braquiópodos carboníferos de la Cordillera Cantábrica (Orthida, Strophomenida y Rhynchonellida). Memoria del Instituto Geologico y Minero de España, 96:1-291.

Martínez Chacón, M.L. 2008. Material tipo de braquiópodos carboníferos, conservado en el Museo del Departamento de Geología de la Universidad de Oviedo. Trabajos de Geología (Universidad de Oviedo), 28:97-118.

Martínez Chacón, M.L. and García-Alcalde, J.L. 1978. La génesis del koskinoide en braquiopodos articulados. Revista de la Facultad de Ciencias, Universidad de Oviedo, 17-19:261-279.

Massa, D., Termier, G., and Termier, H. 1974. Le Carbonifère de Libye occidentale, stratigraphie et paléontologie. Compagnie Française des Pétroles, Notes et Mémoires, 11:139-206.

McIntosh, M.J. 1974. Some Scottish Carboniferous davidsoniacean brachiopods. Scottish Journal of Geology, 10:199-222.

Mergl, M. and Massa, D. 1992. Devonian and Lower Carboniferous brachiopods and bivalves from western Libya. Biostratigraphie du Paléozoïque, 12:1-115.

Mergl, M. and Nolčová, L. 2016. Phenotypic plasticity of colour-patterned Plectodonta (Strophomenida, Brachiopoda) from the Lower Devonian of the Barrandian area (Czech Republic). Bulletin of Geosciences, 91:653-660.

Miloradovich, B.V. 1947. O dvukh novykh rodakh brakhiopod iz verkhnego paleozoia Arktiki. Société Impériale des Naturalistes de Moscou, Bulletin (Géologique), 22:91-99. (In Russian)

Mortelmans, G. 1969. L'étage Tournaisien dans sa localité-type. Compte-Rendu du 6ème Congrès International de Stratigraphie et de Géologie du Carbonifère, Sheffield 1967, 1:19-44.

Mortelmans, G. 1973. Evolution paléoécologique et sédimentologique du Calcaire de Tournai: quelques lignes directrices. Bulletin de la Société belge de Géologie, de Paléontologie et d'Hydrologie, 82:141180.

Mottequin, B. 2004. The genus Biernatella Baliński, 1977 (Brachiopoda) from the late Frasnian of Belgium. Bulletin de l'Institut royal des Sciences naturelles de Belgique, Sciences de la Terre, 74 (supplément):49-58.

Mottequin, B. 2008a. Late middle Frasnian to early Famennian (Late Devonian) strophomenid, orthotetid and athyridid brachiopods from southern Belgium. Journal of Paleontology, 82:1052-1073. 
Mottequin, B. 2008b. New observations on Upper Devonian brachiopods from the Namur-Dinant Basin (Belgium). Geodiversitas, 30:455-537.

Mottequin, B. 2010. Mississippian (Tournaisian) brachiopods from the Hook Head Formation, County Wexford (south-east Ireland). Special Papers in Palaeontology, 84:243-285.

Mottequin, B., Aretz, M., Herbig, H.-G., Baidder, L., Kaoukaya, A., and Denayer, J. 2017. New insight on Carboniferous (Viséan) brachiopods from eastern Tafilalt (Morocco). Geological Journal, 52:217-233.

Mottequin, B. and Brice, D. 2016. Upper and uppermost Famennian (Devonian) brachiopods from north-western France (Avesnois) and southern Belgium. Geologica Belgica, 19:121-134.

Mottequin, B., Brice, D., Marion, J.-M., and Simon, E. 2016. Plicathyridine brachiopods (Athyridida) from the Frasnian (Late Devonian) of Western Europe and Middle East. Geobios, 49:381-393.

Mottequin, B. and Legrand-Blain, M. 2010. Late Tournaisian (Carboniferous) brachiopods from Mouydir (Central Sahara, Algeria). Geological Journal, 45:353-374.

Mottequin, B. and Poty, E. 2016. Kellwasser horizons, sea-level changes and brachiopod-coral crises during the late Frasnian in the Namur-Dinant Basin (southern Belgium): a synopsis. Geological Society, London, Special Publications, 423:235-250.

Mottequin, B. and Sevastopulo, G. 2009. Predatory boreholes in Tournaisian (Lower Carboniferous) spiriferid brachiopods. Lethaia, 42:274-282.

Mottequin, B., Sevastopulo, G. and Simon, E. 2015. Micromorph brachiopods from the late Asbian (Mississippian, Viséan) from northwest Ireland (Gleniff, County Sligo). Bulletin of Geosciences, 90:307-330.

Mottequin, B. and Simon, E. 2015. Diversity of athyridide brachiopods during the Late Devonian-Tournaisian in southern Belgium. Strata (série 1), 16:103-104.

Mottequin, B. and Simon, E. 2017. Revision of some spiriferide and spiriferinide brachiopods from the historical type area of the Tournaisian Stage (Carboniferous, southern Belgium). Paläontologische Zeitschrift. doi: $10.1007 / \mathrm{s} 12542-017-0359-3$

Mourlon, M. 1881. Géologie de la Belgique, Volume 2. Bruxelles, Hayez.

Muir-Wood, H. and Cooper, G.A. 1960. Morphology, classification and life habits of the Productoidea (Brachiopoda). The Geological Society of America, Memoir, 81:1-447.

Mundy, D.J.C. 1994. Microbialite-sponge-bryozoancoral framestones in Lower Carboniferous (Late Viséan) buildups of Northern England (UK). Canadian Society of Petroleum Geologists, Memoir, 17:713-729.

Öpik, A.A. 1934. Über die Klitamboniten. Tartu Ulikooli Geoloogia-Instituudi Toimestuesed Acta et Commentationes Universitatis Tartuensis, 39:1-239.
Phillips, J. 1836. Illustrations of the geology of Yorkshire, Part 2. The mountain limestone district. John Murray, London.

Pirlet, H. 1967. Nouvelle interprétation des carrières de Richelle; le Viséen de Visé. Annales de la Société géologique de Belgique, 90:B299-328.

Pocock, Y.P. 1968. Carboniferous schizophoriid brachiopods from Western Europe. Palaeontology, 11:64-93.

Poty, E. 1982. Paléokarsts et brèches d'effondrement dans le Frasnien moyen des environs de Visé. Leur influence dans la paléogéographie dinantienne. Annales de la Société géologique de Belgique, 105:315-337.

Poty, E. 1997. Devonian and Carboniferous tectonics in the eastern and southern part of the Brabant Massif (Belgium). Aardkundige Mededelingen, Leuven University Press, 8:143-144.

Poty, E. 2016. The Dinantian (Mississippian) succession of southern Belgium and surrounding areas: stratigraphy improvement and inferred climate reconstruction. Geologica Belgica, 19:177-200.

Poty, E., Aretz, M. and Hance, L. 2014. Belgian substages as a basis for an international chronostratigraphic division of the Tournaisian and Viséan. Geological Magazine, 151:229-243.

Poty, E. and Delculée, S. 2011. Interaction between eustacy and block-faulting in the Carboniferous of the Visé-Maastricht area (Belgium, The Netherlands). Zeitschrift der Deutschen Gesellschaft für Geowissenschaften, 162:117-126.

Poty, E., Devuyst, F.-X., and Hance, L. 2006. Upper Devonian and Mississippian foraminiferal and rugose coral zonations of Belgium and Northern France, a tool for Eurasian correlations. Geological Magazine, 143:829-857.

Poty, E., Hance, L., Lees, A., and Hennebert, M. 2002. Dinantian lithostratigraphic units (Belgium). Geologica Belgica, 4:69-94.

Rachebœuf, P.R. 1991. Nouveaux brachiopodes leptaeninés et chonetacés du Dévonien inférieur du Massif Armoricain (NW France). Revue de Paléobiologie, 10:1-19.

Reed, F.R.C. 1954. Lower Carboniferous brachiopods from Scotland. Proceedings of the Leeds Philosophical and Literary Society, Scientific section, 6:180190.

Roberts, J. 1971. Devonian and Carboniferous brachiopods from the Bonaparte Gulf Basin, northwestern Australia. Bureau of Mineral Resources, Geology and Geophysics, Bulletin, 122:1-319.

Rong, J.Y. and Cocks, L.R.M. 1994. True Strophomena and a revision of the classification and evolution of strophomenoid and "strophodontoid" brachiopods. Palaeontology, 37:651-694.

Rowley, R.R. 1900. Descriptions of new species of fossils from the Devonian and the Subcarboniferous rocks of Missouri. American Geologist, 25:261-273.

Sarytcheva, T.G. and Sokolskaya, A.N. 1952. Opredelitel' paleozoiskikh brakhiopod Podmoskovnoi kot- 
loviny. Akademiia Nauk SSSR, Paleontologicheskii Institut, Trudy, 38:1-307. (In Russian)

Sarytcheva, T.G., Sokolskaya, A.N., Beznosova, G.A., and Maksimova, S.V. 1963. Brakhiopody i paleogeografiia Karbona Kuznetskoi kotloviny. Akademiia Nauk SSSR, Paleontologicheskii Institut, Trudy, 95:1547. (In Russian)

Schuchert, C. 1893. Classification of the Brachiopoda. American Geologist, 11:141-167.

Schumann, D. 1969. "Byssus"-artige Stielmuskel-Konvergenzen bei artikulaten Brachiopoden. Neues Jahrbuch für Geologie und Palaeontologie, Abhandlungen, 133:199-210.

Shi, G.R., Chen, Z.Q., and Zhan, L.P. 2005. Early Carboniferous brachiopod faunas from the Baoshan block, west Yunnan, southwest China. Alcheringa, 29:31-85.

Smyth L.B. 1930. The Carboniferous rocks of Hook Head, County Wexford. Proceedings of the Royal Irish Academy (section B), 39:523-566.

Sokolskaya, A. N. 1954. Strofomenidy Russkoi Platformy. Akademiia Nauk SSSR, Paleontologeskii Institut, Trudy, 51:1-191. (In Russian)

Sour-Tovar, F., Alvarez, F., and Martínez Chacón, M.L. 2005. Lower Mississippian (Osagean) spire-bearing brachiopods from Canon de la Peregrina, north of Ciudad Victoria, Tamaulipas, northeastern Mexico. Journal of Paleontology, 79:469-485.

Sowerby, J. de C. 1840. The Mineral Conchology of Great Britain, Volume 7, Part 1. Published by the author, London.

Spjeldnaes, N. 1984. Epifauna as a tool in autoecological analasis of Silurian brachiopods. Special Papers in Palaeontology, 32:225-235.

Sun, Y.-L. and Baliński, A. 2008. Silicified Mississippian brachiopods from Muhua, southern China: Lingulids, craniids, strophomenids, productids, orthotetids, and orthids. Acta Palaeontologica Polonica, 53:485-524.

Sun, Y.-L. and Baliński, A. 2011. Silicified Mississippian brachiopods from Muhua, southern China: Rhynchonellides, athyridides, spiriferides, spiriferinides, and terebratulides. Acta Palaeontologica Polonica, 56: 793-842.

Termier, G. and Termier, H. 1950. Paléontologie marocaine. II, Invertébrés de l'Ere primaire. Fascicule 2, Bryozoaires et brachiopodes. Notes et Mémoires du Service géologique du Maroc, 77:1-253.

Thomas, G.A. 1958. The Permian Orthotetacea of Western Australia. Bureau of Mineral Resources, Geology and Geophysics, Bulletin, 39:1-159.

Thomas, G.A. 1971. Carboniferous and Early Permian brachiopods from Western and Northern Australia. Bureau of Mineral Resources, Geology and Geophysics, Bulletin, 56:1-277.
Thomas, I. 1910. The British Carboniferous Orthotetinae. Great Britain Geological Survey Memoir 1(2):83-134.

Waagen, W.H. 1883. Salt Range Fossils. I. ProductusLimestone Fossils. Geological Survey of India, Memoirs, Palaeontologia Indica (Series 13), 2:391-546.

Waagen, W.H. 1884. Salt Range fossils, Volume 1, Part 4. Productus Limestone fossils, Brachiopoda. Memoirs of the Geological Survey of India, Palaeontologia Indica (Series 13), 3-4:547-728.

Weller, S. 1914. The Mississippian Brachiopoda of the Mississippi Valley Basin. Illinois State Geological Survey Monograph, 1:1-508.

White, C.A. 1860. Observations upon the geology and paleontology of Burlington, lowa and its vicinity. Boston Journal of Natural History, 7:209-235.

Williams, A. 1953. The classification of the strophomenoid brachiopods. Washington Academy of Sciences Journal, 43:1-13.

Williams, A. 1965. Suborder Strophomenidina, p. 362412. In Moore, R.C. (ed.), Treatise on Invertebrate Paleontology. Part H, Brachiopoda. Geological Society of America and University of Kansas Press, New York and Lawrence, 1-927.

Williams, A. and Brunton, C.H.C. 1993. Role of the shell structure in the classification of the orthotetidine brachiopods. Palaeontology, 36:931-966.

Williams, A. and Brunton, C.H.C. 2000. Suborder Orthotetidina, p. 644-689. In Kaesler, R.L. (ed.), Treatise on Invertebrate Paleontology, Part H (Revised), 3. Geological Society of America and University of Kansas, Boulder, Colorado, and Lawrence, Kansas, 13226.

Williams, A., Carlson, S.J., Brunton, C.H.C., Holmer, L.E., and Popov, L.E. 1996. A supra-ordinal classification of the Brachiopoda. Philosophical Transactions of the Royal Society of London (series B), 351:1171-1193.

Xu, H.K. and Yao, Z.G. 1988. Brachiopods, p. 263-326. In Yu, C.M. (ed.), Devonian-Carboniferous boundary in Nanbiancun, Guilin, China-Aspects and records. Science Press, Beijing.

Żakowa, H. 1989. Orthid brachiopods from the Upper Viséan (Carboniferous) of the Świętokrzyskie Mts., Poland. Acta Palaeontologica Polonica, 34:91-124.

Ziegler, P.A. 1990. Geological atlas of Western and Central Europe (Second edition). Shell Internationale Petroleum Maatschappij B.V., Den Haag.

Zong, P., Ma, X., Xue, J., and Jin, X. 2016. Comparative study of Late Devonian (Famennian) brachiopod assemblages, sea level changes, and geo-events in northwestern and southern China. Palaeogeography, Palaeoclimatology, Palaeoecology, 448:298-316. 